\title{
Art déco e indústria Brasil, décadas de 1930 e 1940
}

\section{Telma de Barros Correia ${ }^{1}$}

RESUMO: Este artigo analisa as características assumidas pela arquitetura de tendência art déco em construções ligadas à indústria - moradias, igrejas, escolas, clubes, fábricas etc. erguidas no Brasil nas décadas de 1930 e 1940, investigando o repertório formal utilizado em diferentes tipologias. Faz uma análise mais detalhada das construções criadas pela Companhia Industrial Fiação de Tecidos Goyanna, em Pernambuco, no período entre 1937 e o final da década de 1940. Trata-se de um conjunto notável pela unidade formal, vinculada à linguagem art déco, e pelo emprego de soluções inovadoras em termos de forma e de programa.

PALAVRAS-CHAVE: Arquitetura industrial. Indústria. Art deco. Vilas operárias. Goiana. Brasil.

ABSTRACT: The aim of this article is to analyze the characteristics of Art Deco tendencies in buildings related to the industry - as houses, churches, schools, clubs, plants etc - in Brazil during the 1930s and 1940s. It studies the formal repertory used in different types of construction and develops a more detailed analysis of a complex of constructions by the firm Companhia Industrial Fiação de Tecidos Goyanna, in the state of Pernambuco, built during the period between 1937 and the end of 1940s. The presented group of constructions is notable for the formal coherence, associated with the Art Deco language, and for the use of innovative program and form solutions.

KEYWORDS: Industrial Architecture. Industry. Art Deco. Campany Town. Goiana. Brazil.

Art déco na arquitetura

Pouco conhecida e valorizada, a arquitetura que incorpora tendências art déco tem visibilidade desproporcional à sua presença, ainda muito forte, no cenário urbano brasileiro. É freqüente encontrar-se ausente do programa de cursos de arquitetura. Pouco pesquisada, não há consenso - a começar pela
1. Docente do curso de Arquitetura e Urbanismo da Escola de Engenharia de São Carlos-USP. E-mail: <tcorreia@sc.usp.br> 
2. Na arquitetura, a designação art déco começou a disseminar-se apenas na década de 1960 , a partir da exposição Les Annés 25, realizada no Museu de Artes Decorativas de Paris, em 1966. O uso do termo remete à Exposição Internacional de Artes Decorativas e Industriais Modernas, ocorrida em Paris, em 1925, que marcou a consolidação dessa tendência, que encontraria expressões múltiplas na Europa e teria ampla difusão nas Américas. Entretanto, na época em que surgiram e ao longo das décadas seguintes, as manifestações arquitetônicas hoje associadas ao Art déco eram referidas através de outras designações, como jazz modern, estilo moderno, streamlined modern, zigzag modern, "arte decorativa moderna" etc. Ver Maria Lucia Bressan Pinheiro (1997, p. 127) própria designação - entre os que se dedicam a abordar a produção arquitetônica que pode ser a ela vinculada.

Podem ser feitas algumas restrições ao uso do termo Art déco para designar um estilo de arquitetura: o fato de o que se entende por arquitetura art déco englobar uma diversidade de formas; e de que prédios que podem ser vinculados a essa tendência terem sempre aspectos relevantes que podem ser associados a outras vertentes arquitetônicas (neoclássica, eclética, moderna etc.). Nota-se que, no Brasil, há uma variedade de expressões empregadas para designar o que usualmente se considera como art déco. Às vezes, como é o caso de casas urbanas, construções absolutamente tributárias de modelos que remetem à arquitetura colonial e do século XIX - em termos de materiais, técnicas construtivas, implantação, programa e organização dos espaços internos - têm uma fachada com ornamentação de viés art déco. Em outros casos, uma construção quase totalmente vinculada à arquitetura moderna - em termos de programa, materiais, técnicas e forma - apresenta na fachada um (ou vários) elemento de destaque claramente vinculado à ornamentação déco. Este elemento pode, inclusive, ser um grande relógio que, apesar de instrumento utilitário, é tratado como algo claramente ornamental, segundo uma linguagem de viés déco. Em outras ocorrências, uma construção pode remeter à arquitetura moderna - pelo programa, materiais e abolição de ornamentação figurativa das superfícies externas em alvenaria -, ter toda a sua lógica de composição submetida a procedimentos da arquitetura beaux-arts - seja pela adoção de regras referentes à simetria e à hierarquia, pela ênfase conferida ao acesso principal, e pela repartição da fachada em base, corpo e coroamento, seja pela simplificação de elementos da linguagem clássica, como colunas, óculos, frontões etc. - e submeter-se a uma elaboração formal de cunho déco. Portanto, há prédios que apresentam tendências déco que também podem ter aspectos importantes remetendo a outras arquiteturas: à colonial (sobretudo no caso de moradias unifamiliares); à composição clássica (sobretudo no caso de prédios institucionais); ou à linguagem moderna (sobretudo no caso de prédios comerciais e de apartamentos). Outra restrição, assinalada por Maria Lucia Bressan Pinheiro, fundamenta-se no fato de, em seu uso arquitetônico, Art déco haver se difundido partir da década de 1960, muito depois, portanto, da produção que denomina ${ }^{2}$.

Alguns autores nacionais mobilizaram o adjetivo protomoderna para designar determinadas construções - que outros, inclusive esta autora, associam a art déco -, nas quais a ornamentação se desloca das fachadas para a volumetria, configurando composições compostas que assumem um nítido caráter decorativo, ao qual, freqüentemente, correspondiam detalhes decorativos de viés claramente déco no desenho de portões e luminárias e na ornamentação de portarias. $\bigcirc$ termo foi proposto inicialmente no artigo Protomodernismo em Copacabana, publicado em 1988, para definir uma produção arquitetônica realizada nas décadas de 1930 e 1940, de características mais ou menos homogêneas, articulando elementos que, para os autores, permitem considerar 
os prédios "ao mesmo tempo clássicos e modernos"3. $\bigcirc$ adjetivo protomoderno foi retomado posteriormente em estudo acerca de uma produção de arquitetura com características semelhantes à investigada pelos pesquisadores cariocas, produzida no Recife entre 1930 e 19554. Outra pesquisa realizada sobre a arquitetura produzida nessa última cidade nas décadas de 1930 e 1940 inclui construções de linhas art déco no que é nomeado de "iniciativas modernizantes" 5 . Em pesquisa sobre Campina Grande, na Paraíba, o conceito de "arquitetura modernizante de orientação racionalista" foi mobilizado para designar alguns prédios construídos entre as décadas de 1930 e 1950, de modo a diferenciálos da vasta produção investigada sob a classificação de art déco ${ }^{6}$. É importante o esforço desses autores em buscar precisar melhor tal vertente arquitetônica, embora as alternativas propostas coloquem algumas questões. A principal repousa no fato de não estarem definidas de forma autônoma, mas em relação à "arquitetura moderna". No caso da expressão protomoderna, outra dificuldade colocada diz respeito ao fato de que, ao contrário do que a palavra sugere, não se trata de uma arquitetura que se desenvolveu anteriormente à moderna, mas sim de forma simultânea a esta, durante algumas décadas.

Diante das imprecisões das denominações alternativas, a nosso ver, Art déco - apesar de suas limitações - ainda se coloca como o termo mais apropriado e abrangente para categorizar uma determinada tendência de arquitetura que se difunde no país entre a década de 1930 e meados dos anos 1950, na medida em que dá conta de características relevantes dessa produção e está claramente vinculado a um período específico.

Expresso em pinturas, esculturas, prédios, móveis, rádios e objetos, o gosto déco está vinculado a um conjunto de manifestações artísticas que se propagou a partir dos anos vinte e viveu seu apogeu na década de 1930. Na arquitetura, recebeu impulsos do cubismo, do futurismo, do expressionismo e de outros movimentos das artes plásticas, ao mesmo tempo em que absorveu influências diversas de arquiteturas anteriores e contemporâneas. Concilia aspectos do racionalismo moderno e vínculos com o ecletismo, representando uma "síntese formal da estilização eqüidistante da vanguarda e da tradição"7 e "conjugando as tradições acadêmicas beaux-arts de hierarquização volumétrica e decorativista, com a negação do historicismo"8.

Um dos seus vínculos com a arquitetura beaux-arts situa-se em seu apelo decorativo, que se expressa através da volumetria em composições marcadas pelo jogo de formas geométricas e/ou através de fachadas com elementos figurativos de forte conotação ornamental. Outro vínculo da arquitetura de viés art déco com o passado diz respeito ao uso - com certa freqüência - do método beaux-arts de composição, pela adoção de regras referentes a simetria, axialidade e hierarquia na distribuição da planta, na organização das fachadas e na disposição da volumetria, expressas, entre outras coisas, na ênfase conferida ao acesso principal e na repartição da fachada em base, corpo e coroamento. Um terceiro vínculo diz respeito ao uso - após submetê-los a operação de simplificação - de elementos da linguagem clássica, como colunas, óculos,
3. Cf. Luis Paulo Conde et al. (1988, p. 72). Segundo os autores, em termos urbanísticos esta arquitetura se caracteriza por: busca de unidade compositiva; noção de continuum edificado; e respeito à rua-corredor. Com freqüência, as fachadas adotam uma composição tripartida na vertical, segundo as regras de composição clássica, com a base, o corpo e o coroamento do edifício recebendo tratamentos diferenciados. $\mathrm{O}$ uso de formas arredondadas, o predomínio dos cheios sobre os vazios e o escalonamento no jogo de volumes também são características assinaladas na composição das fachadas. Os autores identificam decorações com influências art déco como predominantes nos interiores e portões de acesso dos prédios que identificam como protomodernos. Idem, p. $70-71$.

4. Ver Paulo R. Andrade (1993, p. 73-74). Andrade afirma que, da tradição clássico-acadêmica, esta arquitetura tende a recuperar o emprego da modinatura como meio de expressão arquitetônica, a composição tripartida na vertical (base, corpo e coroamento) e a simetria axial e frontalidade. Em comum com a arquitetura moderna, situa-se a tendência à abstração e simplificação, a ausência de ornamentação figurativa, a tendência a uma espacialidade mais dinâmica $\mathrm{e}$ complexa, o uso freqüente de volumes "puros" e a atenção a uma noção de racionalidade construtiva associada ao emprego de novas tecnologias, como o concreto armado e o elevador.

5. Cf. G. Naslavsky (1998, p 78).

6. Ver Marcus Vinicius Dantas de Queiroz (2008, p. 222).

7. Cf. V. M. Lampugnani (1989, p. 27).

8. Cf. Juan P. Margenat (2000, p. 14). 
9. Cf. Maria Lucia Bressan Pinheiro (1997, p. 128129).

10. Idem, p. 127.

11. Cf. E. P. Sigaud (1943, p. 35).

12. PERSPECTIVA e projeto definitivo (1939, p. 17-18). frontões, capitéis, pilastras e platibandas. Esses vínculos, entretanto, mostram-se mais ou menos fortes, em diferentes tipologias. Assim, as fachadas simétricas foram freqüentes, sobretudo, em edifícios de apartamentos, em prédios comerciais, industriais e públicos, ou em casas geminadas quando compondo conjuntos. Analisando a arquitetura residencial em São Paulo, Maria Lucia Bressan Pinheiro observou que, nas residências unifamiliares, predominaram as composições assimétricas, possivelmente por esta "parecer gozar de uma maior liberdade formal e compositiva"9.

aspecto inovador da arquitetura art déco situa-se na freqüente simplificação geometrizante de seus elementos decorativos e na diversificação e atualização de suas fontes de influência ornamental ${ }^{10}$. Sob o último aspecto, incorporou referências à máquina, às vanguardas artísticas, a manifestações de arte primitiva e de arquiteturas da Antiguidade, assim como o uso cenográfico da luz artificial. Uma matéria publicada em 1943, na revista A Casa, ilustrada por uma frisa com ornamentos de viés déco em baixo relevo, defendia essa renovação da decoração, de modo a ajustá-la à arquitetura que se modificava:

A decoração supérflua, monótona e inexpressiva impressiona mal o nosso espírito, e a transplantação indébita dos motivos da arquitetura clássica para a arquitetura contemporânea é norma aberrante de todos os preceitos da arte. Após a fase do exagero segue-se o justo equilíbrio. Os atuais interiores, executados com simplicidade e perfeita harmonia com as linhas externas, revelam que já se vai chegando ao desejado ajustamento da ornamentação com o edifício ${ }^{11}$.

Um amplo conjunto de temas compõe o repertório decorativo art déco, incluindo motivos figurativos estilizados, elementos geométricos abstratos ou formas curvas aerodinâmicas. Tais motivos são inspirados em máquinas, na fauna, na flora, em temas associados a culturas antigas, e na linguagem clássica. Referências associadas a construções egípcias e/ou astecas podem ser identificadas no geometrismo; uso de prisma ortogonal, escalonamento; sobreposição de planos de fachadas e baixos relevos com desenhos geométricos. No Brasil, temas da arte marajoara foram mobilizados na ornamentação de interiores e exteriores de tendências déco. Em 1939, matéria na revista A Casa, apresentando uma residência projetada pelo arquiteto Roberto Lacombe e por Flavio Barbosa, defendia a compatibilidade entre o uso profuso de decoração e o "espírito funcional" do "moderno":

Por este projeto conclui-se que num terreno de 10 metros apenas pode levantar-se uma casa original, cheia de ângulos e saliências que a embelezam, sem prejuízo do espírito funcional da planta baixa [...]. O projeto [...] em estilo bem moderno, destaca-se pela decoração que é bem nossa, emprestando ao prédio certo espírito de brasilidade. Parecerá a muita gente imprópria a frase porque em geral quando se fala em espírito de brasilidade tem-se em mente o colonial. Mas a decoração marajoara adapta-se perfeitamente ao moderno, dando-the cunho artístico. ${ }^{12}$ 
Se, na casa citada, a profusa ornamentação foi mostrada como compatível com o "moderno", em outra - também de viés art déco, construída no Rio de Janeiro segundo projeto do arquiteto paulista Alfredo Ernesto Becker -, procurou-se assinalar as qualidades estéticas de uma composição sóbria, argumentando-se que a moradia "tem a beleza da verdadeira arquitetura, não obstante a sobriedade e rigidez das linhas modernas" 13 .

Esta última casa é um exemplo de projeto de viés déco, onde a ornamentação se desloca das fachadas para a volumetria, cujo tratamento assume cunho decorativo. Nesta vertente, situam-se projetos - especialmente de construções de maior porte - que autores antes mencionados definem como protomodernos.

As máquinas, especialmente os grandes navios, foram uma fonte importante de inspiração desta arquitetura: nela os vão circulares - muitas vezes dispostos enfileirados - distanciam-se dos óculos e remetem às escotilhas de navios (ou a janelas de aviões); os gradis de ferro adotam, com freqüência, formas despojadas, inspiradas em guarda-corpos de passadiços; enquanto os volumes arredondados sugerem torres de comando ou convés de popa. Engrenagens de máquinas e motores também inspiraram a forma de ornamentos. Mastros, dispostos nas fachadas, remetiam a navios, enquanto grandes transatlânticos construídos na década de 1930 tiveram a decoração de seus interiores amplamente solidária à estética déco. Nessa década, mobiliários vinculados à tendência foram, inclusive, referidos pelo arquiteto Albert Speer como seguindo o "estilo transatlântico"14.

A arquitetura de tendências art déco adotou, com freqüência, princípios de hierarquização, expressos em formas escalonadas e na ênfase ao acesso principal. A construção, muitas vezes, estrutura-se através de uma composição volumétrica integrando formas geométricas - prismas retangulares, elementos cilíndricos, volumes arredondados ou planos, verticais ou horizontais. Em prédios altos foi comum uma composição de prismas retangulares de diferentes alturas, gerando um escalonamento solidário, com ênfase na altura e busca de monumentalidade.

Entre os recursos que integraram o repertório formal do Art déco na arquitetura encontram-se: marquises; balcões em balanço; colunas, frontões, capitéis, pilastras, platibandas e volutas de formas esquemáticas; gradis e caixilhos de metal, inclusive do tipo basculante; ornatos em alto ou baixo relevo, representando formas geométricas, temas florais simplificados, linhas retas, em ziguezague, ou linhas em espirais. Os vãos surgem retangulares, circulares, escalonados ou acompanhando as superfícies curvas das quinas das fachadas. $\bigcirc$ uso cenográfico da luz é amplamente apropriado, tanto através do neon compondo fachadas quanto através de vitrais. Texturas nas superfícies e padrões esquemáticos de cores são outros recursos empregados.
13. CASA projetada pelo arquiteto Alfredo Ernesto Becker (1938, p. 35)

14 .SPEER, 1975, p.32. 
15. BIBLIOTHECA Municipal do Districto Federal (1932, p. 43).

16. Ver Vitor José Baptista Campos (1996, p. 257).
Art déco no Brasil

Nada marcou mais o cenário arquitetônico das cidades brasileiras entre as décadas de 1930 e 1940 que a arquitetura de tendências art déco, que se mostrou capaz de colocar-se como expressão de modernidade, posição que seria ocupada na década seguinte pela arquitetura moderna. Em construções novas ou em fachadas reformadas, a linguagem déco foi, durante aquelas duas décadas, a expressão de renovação da arquitetura de maior alcance junto a diferentes segmentos da população. A justificativa, mobilizada em 1932, para a escolha do estilo para uma biblioteca municipal no Rio de Janeiro, em substituição a um projeto anterior de viés eclético, evidencia tal capacidade desempenhada, na ocasião, pelo Art déco, de traduzir modernidade arquitetônica e progressismo administrativo:

a parte artistica do Edificio estudada pelos architectos officiaes obedecia a um estylo antiquado que não podia de forma alguma coadunar-se ao progressismo de Antonio Prado. Assim sendo, o architecto Elisario Bahiana, da Sociedade Commercial e Construtora, Ltda. encarregou-se de traduzil-a para o moderno, cousa que se desobrigou, com rara felicidade. De facto, a nova fachada simples e bem equilibrada correspondeu plenamente ao objectivo a que se destinava o edifício. Obedecendo ao mesmo critério do exterior foi tratada a parte interna onde a simplicidade característica do Moderno foi alliada ao conforto e hygiene, apanágios da construcção hodierna ${ }^{15}$.

São Paulo. Na arquitetura - na época nomeada freqüentemente "moderna" $\bigcirc$ repertório formal déco imprimiu marcas profundas na paisagem de cidades como o Rio de Janeiro e -, expressou-se inicialmente, sobretudo, em projetos que buscavam traduzir uma noção de modernidade vinculada a programas novos. Este foi o caso dos primeiros arranha-céus que testemunharam a passagem de algumas de nossas capitais à condição de metrópoles; de edifícios institucionais que abrigavam funções de um Estado que se modernizava e expandia; de lojas de departamento que introduziam um novo conceito de comércio vinculado a padrões inéditos de consumo; e de cinemas, clubes e emissoras de rádio que difundiam formas novas de diversão, cultura e lazer. $\bigcirc$ vocabulário também esteve presente em construções que exibiam e testemunhavam as inovações do mundo da produção, como os pavilhões de exposições e as fábricas e suas construções anexas. $\bigcirc$ repertório déco esteve ainda presente, de forma significativa, nos prédios de apartamentos, que propagavam novos modos de morar e de relação entre cidade e moradia. Em inventário sobre a arquitetura de tendência art déco na cidade de São Paulo, Vitor Campos constatou que a tipologia mais freqüente entre os prédios vinculados ao estilo era aquela de uso misto, destinadas à habitação multifamiliar, com pavimento térreo utilizado para fins comerciais ${ }^{16}$. 
Nos arranha-céus, a altura era sublinhada por composições escalonadas ou por elementos verticais de coroamento. Em edifícios institucionais, pretensões de monumentalidade eram favorecidas por composições de matriz clássica que incorporavam decorativismo e hierarquização volumétrica. Os recursos cenográficos que a estética déco oferecia eram solidários com o glamour, a magia e o fascínio suscitados por um cinema, que então explorava recursos técnicos e dramáticos inéditos e alcançava uma grande popularidade entre as massas. Em fábricas, tal vocabulário conciliava uma imagem de modernidade com parcimônia de meios e economia de custos. $\bigcirc$ grande porte dessas construções e as estruturas de concreto presentes em muitas delas eram solidários com os motivos decorativos simples e geométricos. Por outro lado, legislações urbanísticas que exigiam recuos progressivos dos andares superiores dos prédios se compatilizavam a composições volumétricas escalonadas, de linhagem déco, reforçando esta tendência.

Em parte das construções, as referências à linguagem déco restringiam-se a detalhes ornamentais aplicados em fachadas de construções cujas características - em termos de implantação, tecnologia construtiva, volumetria e organização dos espaços internos - seguiam os modelos mais usuais na época, ainda atrelados fortemente a formas difundidas no período colonial e no século XIX.

Em muitos outros casos, entretanto, o repertório formal art déco foi empregado em construções inovadoras em termos de programa-arranha-céus, lojas de departamentos, prédios de apartamentos etc. - e de técnicas construtivas, como as estruturas de concreto armado, os caixilhos de metal etc. Matéria de 1931, sobre o Edifício Pirapitinguy - construído pela Sociedade Commercial e Construtora Ltda., do arquiteto Elisario Bahiana -, sublinhava como, em sua composição de fachadas, as linhas da estrutura articulavam-se com os poucos elementos de cunho meramente ornamental: "Seu estylo, já francamente moderno, diz bem do fim a que se destina, e sua decoração sóbria, casando-se harmoniosamente com as linhas principaes que são as do vigamento estructural, causam uma impressão agradabilíssima"17.

Em prédios de apartamentos, o estilo Art déco traduziu os novos programas em uma arquitetura que alguns observadores da época consideravam capaz de qualificar a paisagem urbana. Matéria sobre prédio de apartamentos - projetado pelo arquiteto Elisario Bahiana - em construção em 1932, no Rio de Janeiro, associa a tipologia à busca de conforto e economia. A disposição interna adotada no projeto é mostrada como condicionada por questões de circulação, máximo aproveitamento do terreno, insolação e iluminação dos ambientes e privacidade em relação aos vizinhos. $\bigcirc$ tratamento da composição volumétrica e das fachadas - em que se enfatizam os materiais de revestimento e as cores - é justificado diante dos impactos causados por prédio deste porte cerca de dez andares - no cenário urbano: 
18. PRÉDIO de Apartamento $(1932,66)$.

\begin{abstract}
19. O estilo missões foi uma vertente estilizada do estilo neocolonial, que remetia, sobretudo, à arquitetura colonial das antigas missões coloniais da América espanhola, incluindo o sudoeste dos Estados Unidos, principalmente no século XVIII, tendo encontrado grande difusão nas Américas, inclusive no Brasil, onde se difundiu, sobretudo, na arquitetura residencial durante as décadas de 1930 e 1940
\end{abstract}

20. ARCHITECTO J. Cordeiro de Azeredo (1928, p. 21).

21. Projetos de tendências art déco publicados na revista $A$ Casa: para casas em cidades (1928, p.41; abr. 1938 , p. 30); para casa de campo (jan. 1932, p. 10); para casa de fim de semana (jun.-jul. 1942, p. 21); para prédio multifamiliar (fev 1939 , p. 31), para edifício de apartamentos (ago.-set. 1938, p. 19; nov.-dez. 1938 , p. 24) e para prédio de uso misto com armazém e moradia (fev. 1938, p. 14).

22. Projetos de tendências art déco de casas térreas ou de dois pavimentos publicados na revista $A$ Casa destinados: ao Rio de Janeiro (1928, p.21; maio 1939, p. 27; nov.-dez. 1939 , p. $14-15$; fev.-mar. 1940, p. 7; jun.-jul. 1942 , p. 16-17); a São Paulo (ago.-set. 1940, p. 19; abr. 1940 , p. 11); a Niterói (jan. 1938 , p. 20 e 22); e a Belém (fev.-abr. 1941, p. 26).

23. Uma longa matéria sobre o Rockfeller Center, por exemplo, é apresentada sem nenhuma referência formal à arquitetura. Ver O CENTRO ROCKFELLER (1938, p. 13 e 40-42)
Sendo a parte externa de um prédio um quase domínio publico, pois está sujeita a apreciação de todos, necessário torna-se que seu aspecto influe agradavelmente não só no ponto de vista individual, como dentro do quadro geral das edificações e do ambiente natural, depreende-se que a architectura externa tem também a maxima importancia [...] A parte externa que obedece a arte moderna um tanto calma promette adaptar-se optimamente ao local. $\bigcirc$ Rio de Janeiro, cidade de sol e céu azul, espelhando-se na esplendorosa Guanabara, requer casas alegres e côres. A fachada do edifício em questão que deverá ser de cor palha, com embasamento de mármore avermelhado e corpo central saliente também no tom do mármore, tendo as decorações em baixo relevo do coroamento em cobre oxidado, proporcionará um contraste de cor de rara belleza ${ }^{18}$.

No caso das residências unifamiliares, observando a revista A Casa, é possível observar como projetos de viés déco começam a ser publicados com regularidade partir de 1932, firmando-se ao longo desta década e até meados da seguinte como a segunda principal tendência - depois do estilo missões ${ }^{19}$ entre os projetos de moradias publicados pela revista. Um dos dois projetos de tendência art déco publicados na edição de dezembro de 1928 da revisła - de autoria do arquiteto J. Cordeiro de Azeredo e destinado ao bairro do Andaraí, no Rio de Janeiro -, foi identificado como uma "pequena residência em arte moderna" 20

A revista A Casa publicou projetos de tendências art déco para uma variedade de programas residenciais: casas em cidades; casa de campo; casa para fim de semana; prédio multifamiliar; edifício de apartamentos; e prédio de uso misto com armazém e moradia ${ }^{21}$. Os projetos de casas térreas ou de dois pavimentos publicados destinavam-se a diferentes cidades, como o Rio de Janeiro, São Paulo, Niterói e Belém²2.

Nesse periódico de arquitetura e engenharia, os projetos eram geralmente apresentados sem textos explicativos, e eram raras as abordagens conceituais ${ }^{23}$. No caso das residências burguesas unifamiliares, o Art déco parecia se colocar (na perspectiva de muitos) como uma das possibilidades à disposição de usuários e projetistas. Tal perspectiva foi acatada, por exemplo, pelos arquitetos: J. Cordeiro de Azeredo - que teve entre seus projetos publicados em A Casa, bangalôs com elementos de viés "pitoresco" e do vocabulário do neocolonial, além de projetos de tendências déco; Alfredo Ernesto Becker - que divulgou, na mesmo revista, projetos com vocabulário art déco e em estilo missões; e Ângelo Bruhns - que projetou, entre as décadas de 1920 e 1940, bangalôs, prédios neocoloniais, construções com elementos de viés déco e filiadas à arquitetura moderna.

O Art déco revelou-se uma linguagem acessível às elites, às classe médias e às classes populares. Na arquitetura, a partir de construções de maior porte, o vocabulário conquistou o gosto popular e disseminou-se em grandes e pequenas residências e em prédios comerciais. Suas linhas geometrizadas especialmente os volumes, os vãos e as superfícies escalonadas - popularizaramse em cidades grandes e pequenas, convertendo-se em marco do cenário urbano brasileiro das décadas de 1930 e 1940. 
Um número significativo de fábricas erguidas no Brasil nas décadas de 1930 e 1940 - bem como suas construções anexas - incorporam elementos vinculados à linguagem art déco. A arquitetura fabril atesta a difusão do gosto déco no país e sua grande aceitação, naquele momento, por parte de industriais, muitos dos quais o mobilizaram na construção de instalações fabris, de equipamentos de uso coletivo, de casas para seus operários e, em casos mais raros, de moradias para gerentes e para seu uso particular. Em visitas realizadas em vários estados do Brasil - apesar das constantes reformas inerentes a espaços vinculados à indústria -, foi possível localizar um volume expressivo de construções que podem ser identificadas como de viés art déco.

Isso pode ser explicado, em parte, pela atualização formal que o Art déco operou, vinculando-se ao mundo industrial e à noção de modernização. A tendência à abstração expressa nesta linguagem - com seus volumes e ornamentos geometrizados - remete ao mundo fabril, reportando-se à forma das máquinas que povoam esse universo, seja como produtos, seja como meios de produção. Na sua vertente streamlined, o Art déco inspirou-se nas formas sinuosas e aerodinâmicas das novas máquinas de velocidade - carros, aviões e transatlânticos.

sucesso do Art déco junto aos industriais também pode ser explicado pelo barateamento dos custos de construção decorrente da simplificação de ornatos que operou. Investigando o sentido da popularização do Art déco em São Paulo, Maria Lucia Bressan Pinheiro considera que decorreu, sobretudo, da "relação direta entre o despojamento de suas linhas e ornamentos e o barateamento da construção"24.

A divulgação de experiências internacionais em revistas especializadas, provavelmente contribuiu para a adoção do vocabulário déco em construções vinculadas a indústrias. Em dezembro de 1931, a Architectura e Construcções publicou matéria - intitulada A Architectura e a Estetica dos Edifícios Industriaes - reproduzida da revista italiana Architectura e Arte Decorativa, incluindo imagens de prédios - caixa d'água, estação de rádio, hangar, matadouro, etc. construídos em outros países, a maioria dos quais de viés déco. Na introdução à matéria reproduzida, informa-se que se trata da divulgação de uma "architectura applicada, com justo criterio, aos edifícios industriaes" 25 e que é propósito da revista "combater em favor dessa architectura que concorrendo para a esthetica das zonas industriaes concorre ao mesmo tempo para elevar o espírito e a cultura do nosso operário" 26. Na matéria reproduzida, a compatibilidade entre a nova linguagem e as construções utilitárias é defendida:
25. A ARCHITECTURA e a estetica dos edifícios industriaes (1931, p. 5)

26. Id., ib. 
27. Id., ib.

28 GUNN, Philip; CORREIA, Telma de Barros. Levantamentos de Campo em vilas operárias e núcleos fabris no Brasil, 1996 a 2005
A architectura, tem hoje uma missão mais utilitaria, mais humana. As leis economicas, estabelecando um equilibrio entre a riqueza e o bem estar, e elevando as classes trabalhadoras, fazem da architectura uma arte que deve reunir o útil ao agradável, isto é deve crear ambientes onde o operário sinta menos o peso do trabalho ${ }^{27}$.

No mundo industrial brasileiro é possível localizar expressões do Art déco em exemplares situados em cidades e no campo, em diferentes estados e regiões. Os exemplos de arquitetura art déco tratados neste artigo foram identificados na pesquisa Vilas e núcleos fabris: Brasil, 181 1-200028. A intenção da pesquisa é investigar a forma (em termos da arquitetura e do desenho urbano) e o significado (em termos de organização do território, do espaço urbano e da moradia) das vilas operárias situadas em áreas urbanas e suburbanas, e de núcleos residenciais no campo. $\bigcirc$ programa de pesquisa é baseado em duas atividades principais: pesquisa bibliográfica e em fontes primárias; e programa de visitas a vilas e núcleos fabris. Portanto, os exemplos de arquitetura fabril de tendências art déco tratados a seguir referem-se apenas a fábricas dotadas de moradias para seus empregados, identificadas em um universo de 185 conjuntos fabris visitados, entre os cerca de 350 pesquisados. Entre os 185 conjuntos fabris visitados, erguidos entre 1811 e as últimas décadas do século XX, em 29 conjuntos foram identificados um ou mais prédios e/ ou conjuntos de moradias de tendências déco. Entre os exemplos de arquitetura fabril de tendência art déco estudados, a Companhia Industrial Fiação de Tecidos Goyanna, no município de Goiana (PE), destaca-se pelo fato de todos os prédios do conjunto - fábrica, armazéns, sorveteria e casas para empregados, gerentes e patrão - filiarem-se a essa tendência, assim como devido às características peculiares da casa do industrial.

O estudo da arquitetura de tendência art déco no âmbito de uma pesquisa desta natureza encontra possibilidades, e limitações, específicas. Entre as possibilidades, está a de indicar o grande alcance do estilo em termos geográficos, mostrando como surge em diferentes regiões do país, em cidades grandes e em pequenas aglomerações. Outra possibilidade está em evidenciar como o estilo foi aplicado em diferentes tipologias, em construções monumentais e em casas operárias simples, evidenciando tratar-se de uma linguagem apropriada por uma grande diversidade de programas e acessível a diferentes classes sociais. A pesquisa também pôde indicar como construções de viés déco foram não só projetadas por especialistas - arquitetos e engenheiros - mas, também, construídas sem um projeto formal, evidenciando o apelo da tendência tanto junto a profissionais formados como em outros segmentos envolvidos na construção. O levantamento também torna possível o registro fotográfico de um número significativo de construções, muitas delas em vias de serem reformadas ou demolidas, em decorrência de reformas de fábricas e do "desmonte" de sua relação com suas vilas operárias e núcleos fabris.

Entre os limites ao estudo da arquitetura de tendência art déco no âmbito de uma pesquisa desta natureza, está a escassez de informações sobre a 
arquitetura das fábricas e de seus anexos - seja nos acervos das próprias fábricas, seja em eventuais arquivos públicos das cidades onde se localizam. Associada a esta escassez de registros, está a dificuldade de identificar os autores da concepção das construções, ou pela dificuldade de localização de projetos originais e de registros de seus autores, ou porque a maioria das construções parece ter sido erguida sem um projeto arquitetônico formal.

Contudo, foi possível identificar projetos de autoria de arquiteto, engenheiros civis e concebidos por industrial. Com base nas informações imprecisas em sua maioria - colhidas na pesquisa de campo e nas características construtivas da maioria das edificações pesquisadas, supomos que grande parte delas foi construída sem seguir um projeto arquitetônico formal. Este foi o caso em Goiana, onde, conforme informação prestada pelo filho do industrial que o sucedeu na administração da fábrica, foi seu pai - indivíduo sem formação profissional na área de construção - quem concebeu de maneira empírica todas as construções decorrentes das ampliações do conjunto fabril ocorridas nas décadas de 1930 e $1940^{29}$.

Assim, a possibilidade de trabalhar com uma produção abrangente - em termos geográficos e de diversidade tipológica, além de extrapolar a produção vinculada a profissionais formados -, encontra como desvantagem as dificuldades de acesso a projetos originais e de identificação de autoria.

Diante do exposto, o enfoque central da pesquisa está, necessariamente, deslocado dos projetistas para os contratantes-construtores-proprietários (que eventualmente somavam a estas funções a concepção dos prédios), analisando uma parcela muito específica da arquitetura de viés art déco - a produzida na ambiência de fábricas - e valorizando, na análise, as demandas específicas desse setor.

Art déco e indústria: alguns exemplos

Em Minas Gerais, alguns elementos de gosto déco se fazem presente em Gouveia, no núcleo fabril erguido pela Companhia Industrial São Roberto a partir de 1932, onde eles surgem em instalações fabris e em equipamentos de uso coletivo (alguns dotados de marquises e de faixas paralelas em alto relevo verticais e/ou horizontais) bem como em moradias (algumas com frontões e ornatos escalonados) ${ }^{30}$ (Figuras 1 e 2).

Ainda em Minas Gerais, também é possível localizar exemplares de gosto déco no prédio dos escritórios da Companhia Renascença Industrial, fundada em 1937, em Belo Horizonte, e nos prédios industriais da Fábrica de Tecidos da Companhia Industrial Itabira do Campo, em Itabirito, e da Fábrica Maria Amália, fundada em 1941, em Curvelo. No primeiro caso, trata-se de um exemplar vinculado a um art déco de linguagem inovadora: um prisma ortogonal, com fachadas não simétricas, dotado de um grande pano de vidro que se
29 Concedida à autora por Nelson Pimentel, no Recife, em janeiro de 2003

30. Esta fábrica de tecidos foi implantada em localidade rural, a dois quilômetros de distância da vila de Gouveia. Junto às suas instalações, ergueu-se um núcleo fabril com cerca de 60 casas, clube, cinema, campo de futebol, igreja, comércio e escola. 

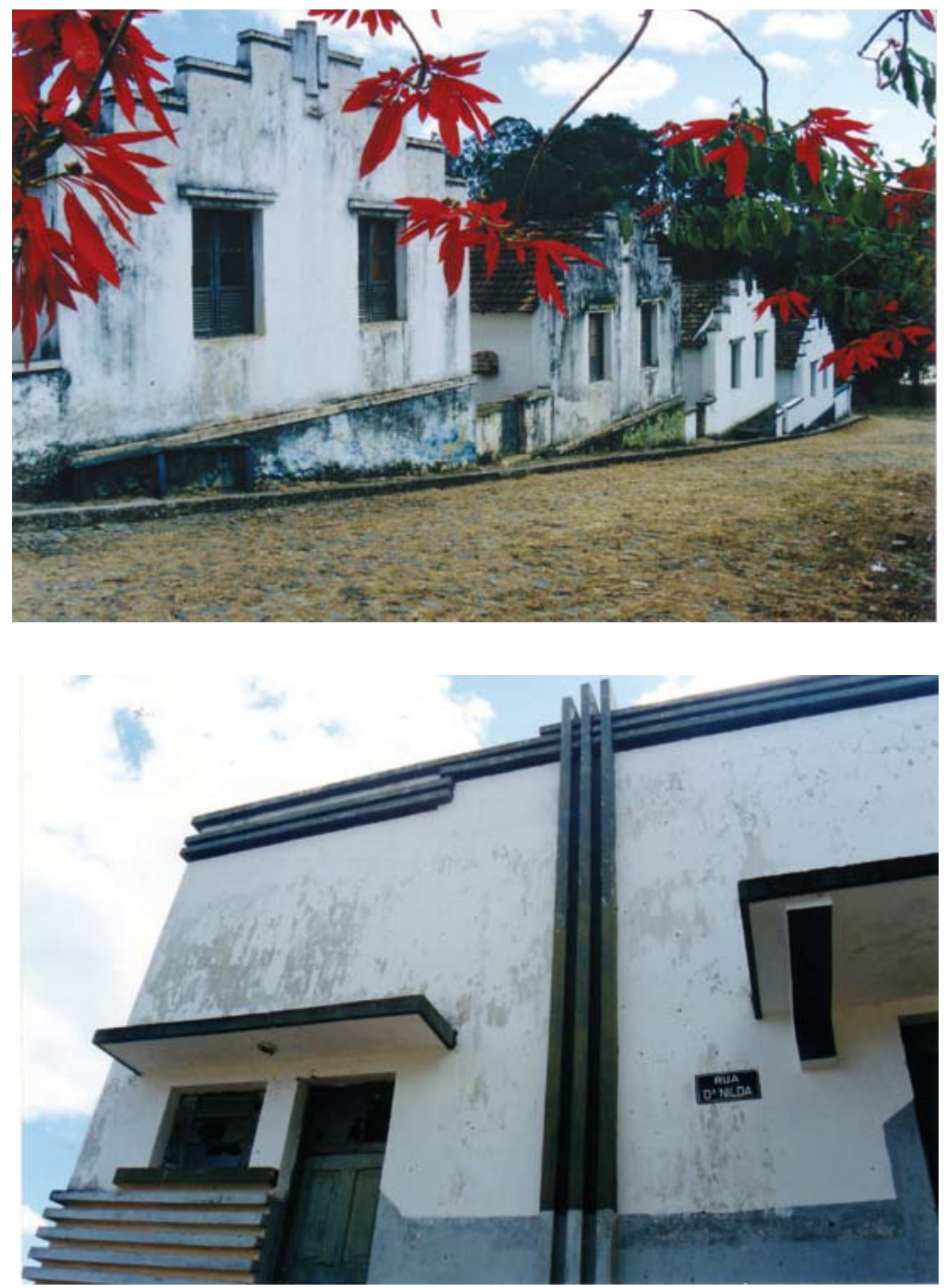

Figuras 1 e 2 - Casas para operários e prédio industrial, edificados a partir de 1932 pela Cia. Industrial São Roberto, em Gouveia, um núcleo fabril localizado no município de Diamantina (MG). Fotografias de Philip Gunn, 1998. 
estende ao longo de uma fachada e em parte de duas outras. Sua decoração limita-se a frisos paralelos em alto e baixo relevo e a formas circulares em baixo relevo. Os dois últimos prédios expressam um viés do Art déco com compromissos mais fortes com a composição beaux-arts, mantendo a simetria no tratamento das fachadas e promovendo uma adaptação, à linguagem déco, de elementos da arquitetura neoclássica - frontões, pilastras e platibandas -, estilizados e simplificados. $O$ prédio da Hidroelétrica do Carioca, criada pela Companhia de Tecidos Santanense, em Pará de Minas, também estiliza e simplifica platibanda, frontão e pilastras, ao mesmo tempo em que introduz apliques escalonados típicos da estética déco (Figuras 3 a 6).

Ainda em Minas Gerais, um caso curioso é o da vila operária da Fiação e Tecelagem João Lombardi, em São João del Rei ${ }^{31}$, em cujas fachadas se vê, em um primeiro plano, um terraço dotado de vão em arco pleno, com cercadura em reboco imitando pedra, que remete ao estilo missões, enquanto, em um segundo plano, surge uma fachada dotada de um frontão de viés déco (Figura 7).

No estado do Rio de Janeiro, o gosto déco se expressa na Fábrica Nacional de Motores: um empreendimento militar erguido em Duque de Caxias entre 1942 e 1944, que teve como chefe de sua Comissão Construtora o brigadeiro e engenheiro aeronáutico Antônio Guedes Muniz ${ }^{32}$. Entre os primeiros prédios edificados, encontra-se um dotado de formas escalonadas e de grandes

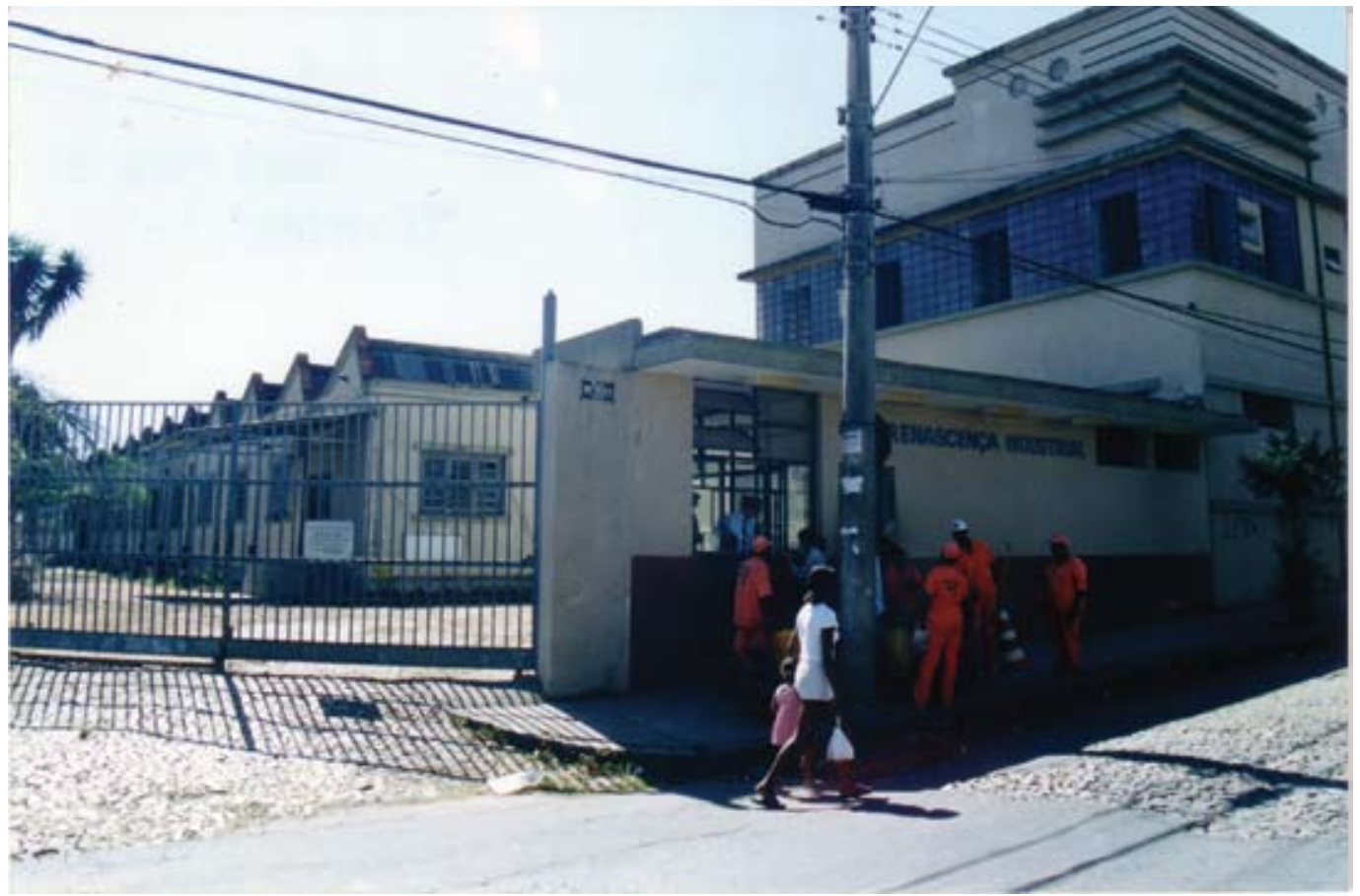

Figura 3 - Prédio de escritórios da Companhia Renascença Industrial, edificado na segunda metade da década de 1930, em Belo Horizonte (MG). Fotografia de Philip Gunn, 1998.
31. Esta fábrica surgiu em 1946, em subúrbio da cidade de São João del Rei, re sultante da fusão de duas outras indústrias pré-existentes. Junto a suas instalações, edificou-se uma vila operária - com cerca de 20 casas - e uma cooperativa de consumo.

32 Fábrica Nacional de Motores S.A. O Observador Econômico e Financeiro, São Paulo, ano 14, n. 160, p. 73-76, maio 1949. 


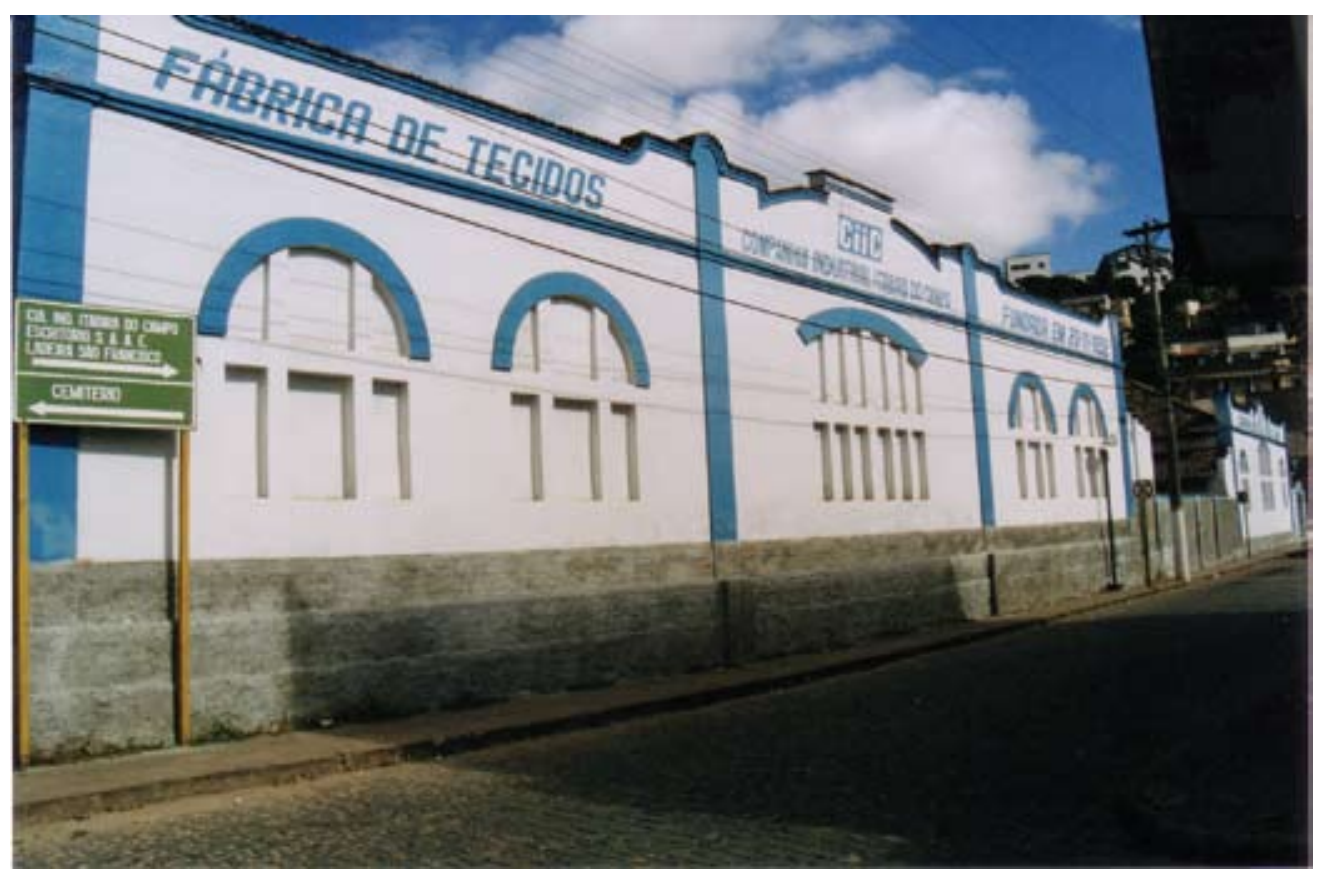

Figura 4 - Fábrica de Tecidos da Companhia Industrial Itabira do Campo, em Itabirito (MG). Fotografia de Philip Gunn, 1998.

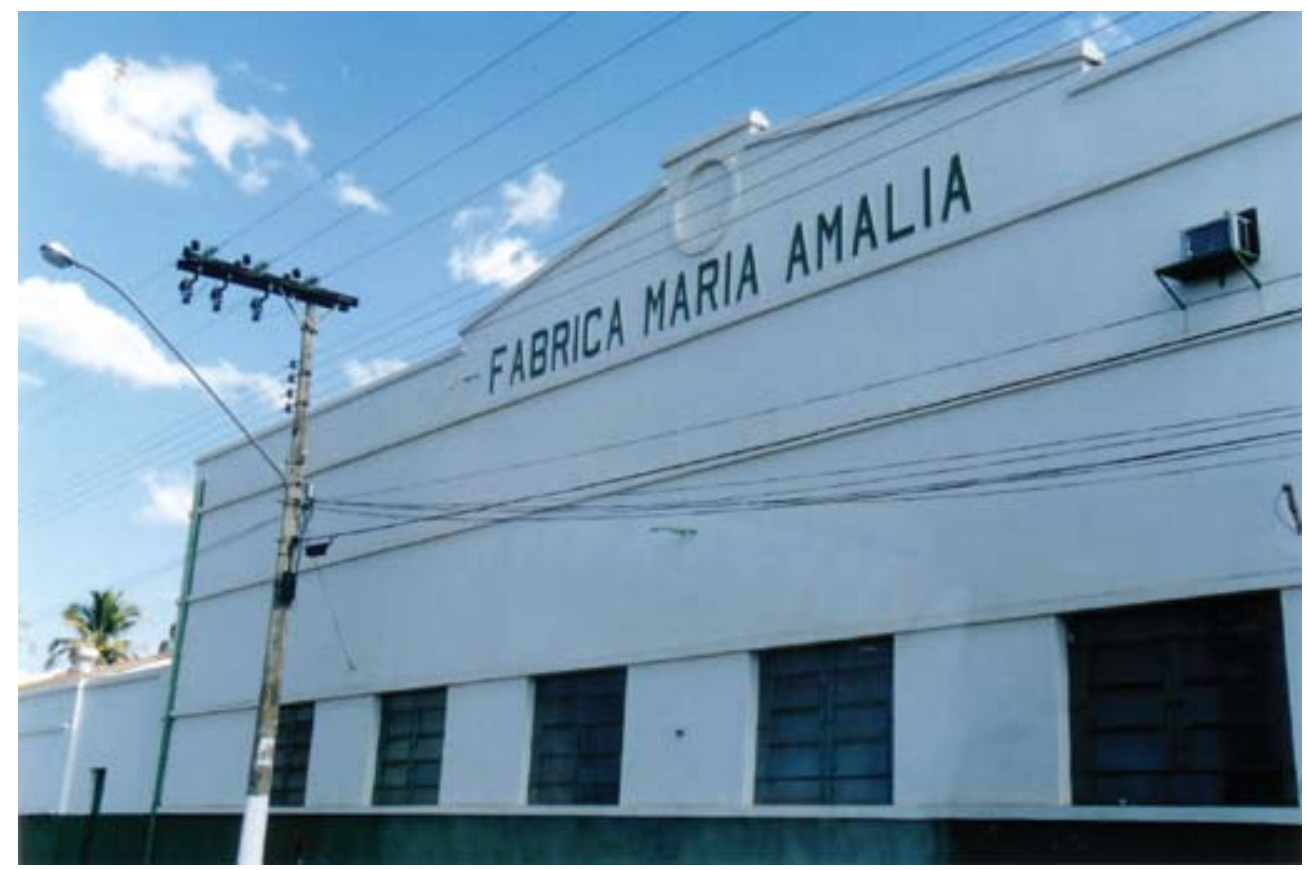

Figura 5 - Fábrica Maria Amália, do Grupo Othon, edificada na década de 1940, em Curvelo (MG). Fotografia de Philip Gunn, 1998. 


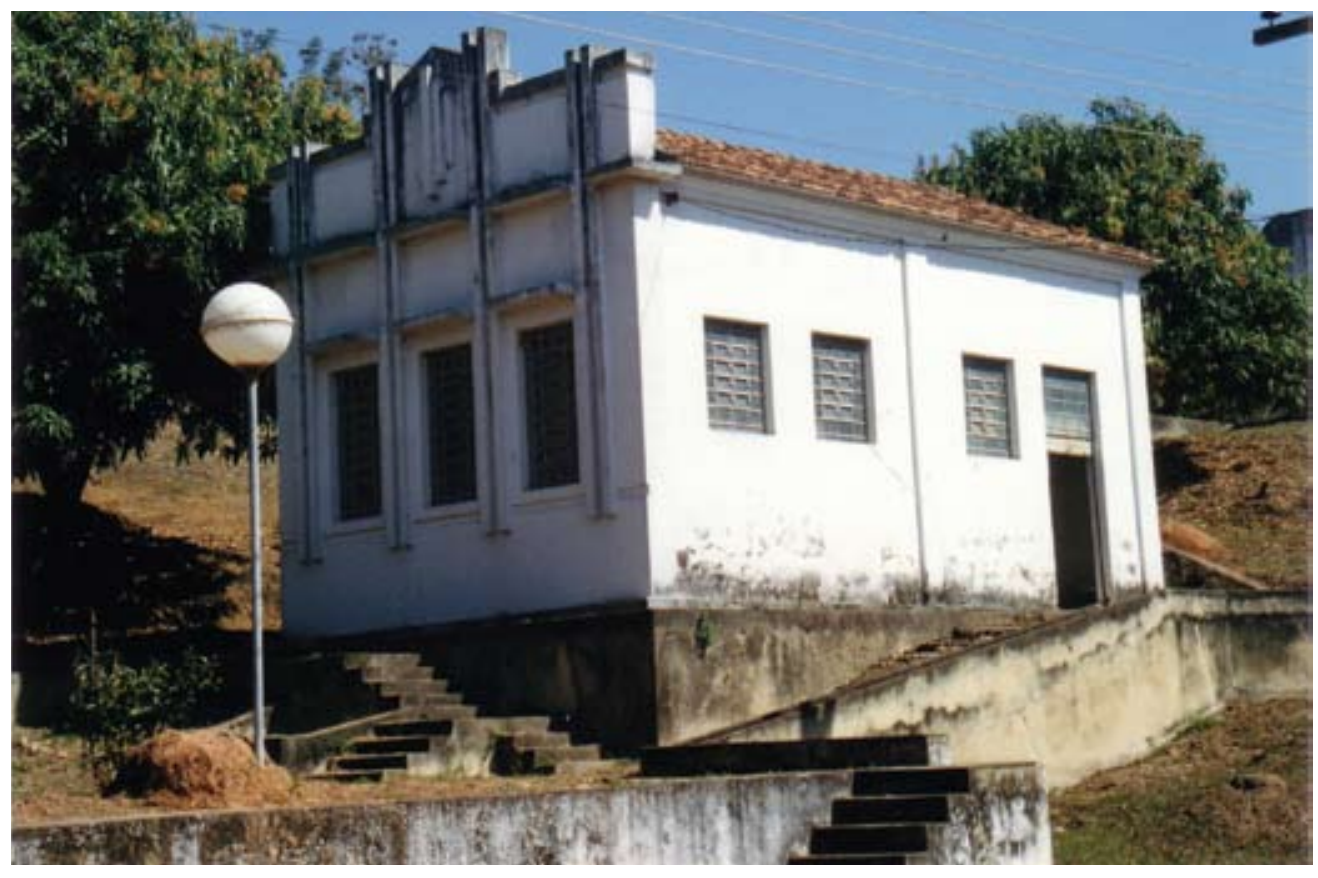

Figura 6 - Prédio da Hidroelétrica do Carioca, da Companhia de Tecidos Santanense, localizado em área rural do município de Pará de Minas (MG). Fotografia de Philip Gunn, 1998.

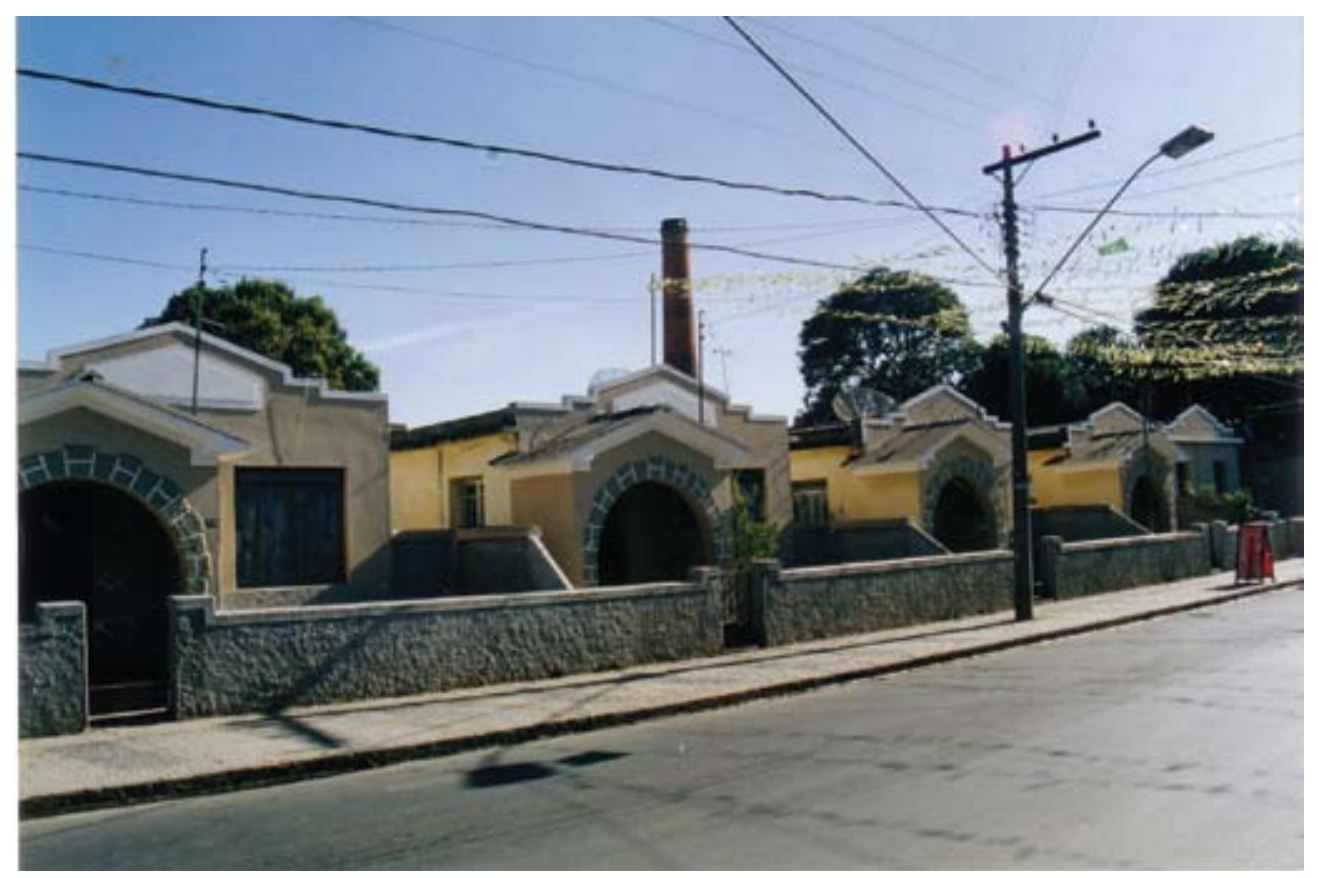

Figura 7 - Vila operária da Fiação e Tecelagem João Lombardi edificada em 1946, em São João del Rei (MG). Fotografia de Philip Gunn, 1998. 
superfícies de vidro e marquises, acompanhando as superfícies curvas da alvenaria das fachadas, assim como duas guaritas de formas streamlined (Figuras 8 e 9).

O prédio da Fábrica Ypu, em Nova Friburgo, segue um vocabulário art déco que se repete em fábricas construídas no estado de São Paulo, tratadas mais adiante. Trata-se de uma composição dominada por uma torre central, cuja verticalidade é reforçada por linhas verticais em relevo, que contrastam com as linhas horizontais dos dois blocos laterais. A torre central demarca o acesso principal - sublinhado por marquise sobre o portão - e ostenta o nome da empresa; e, no alto - dominando a composição -, um grande relógio (Figura 10).
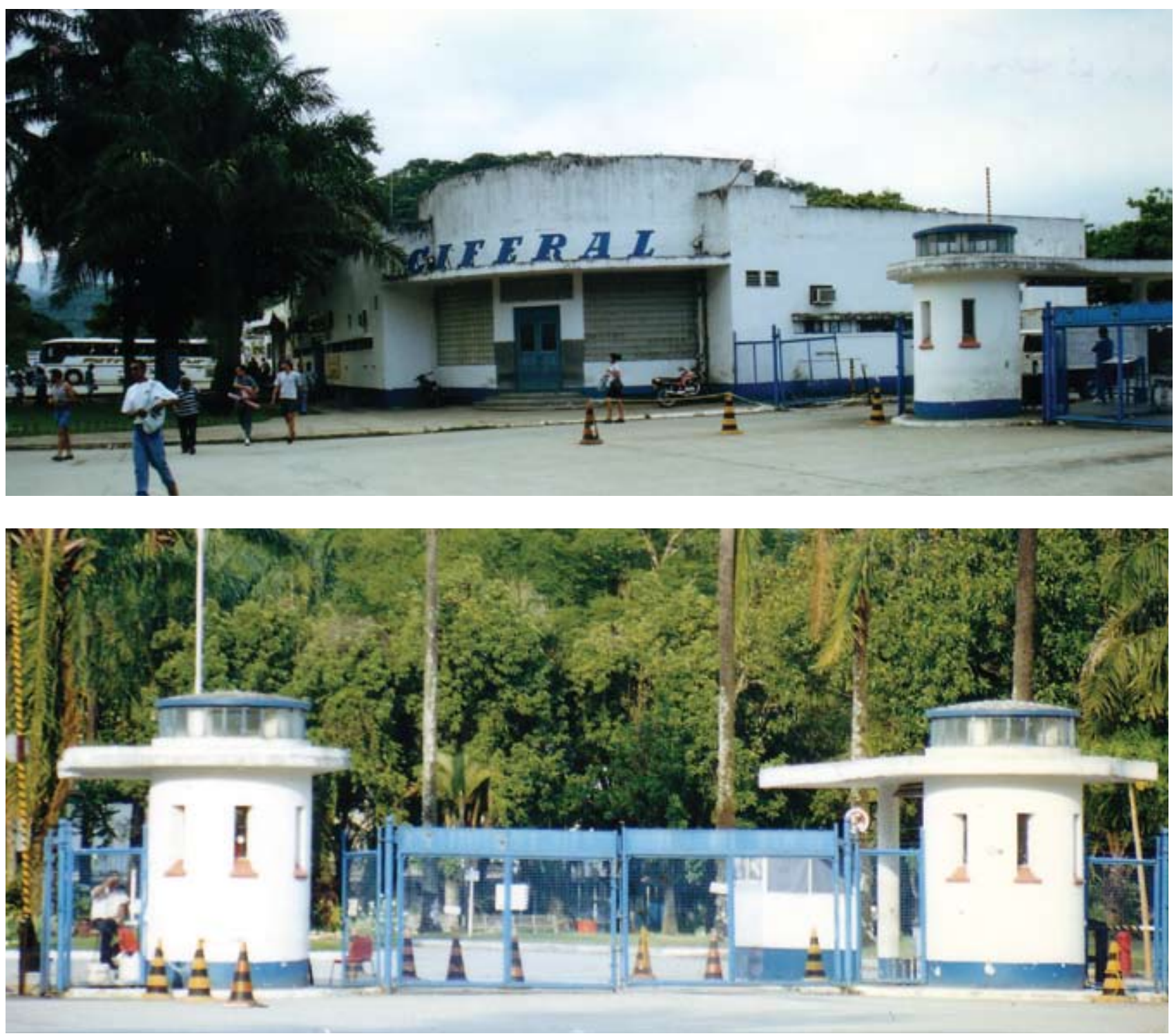

Figuras 8 e 9 - Fábrica Nacional de Motores, erguida na década de 1940, em Duque de Caxias (RJ). Fotografias de Philip Gunn, 1998. 


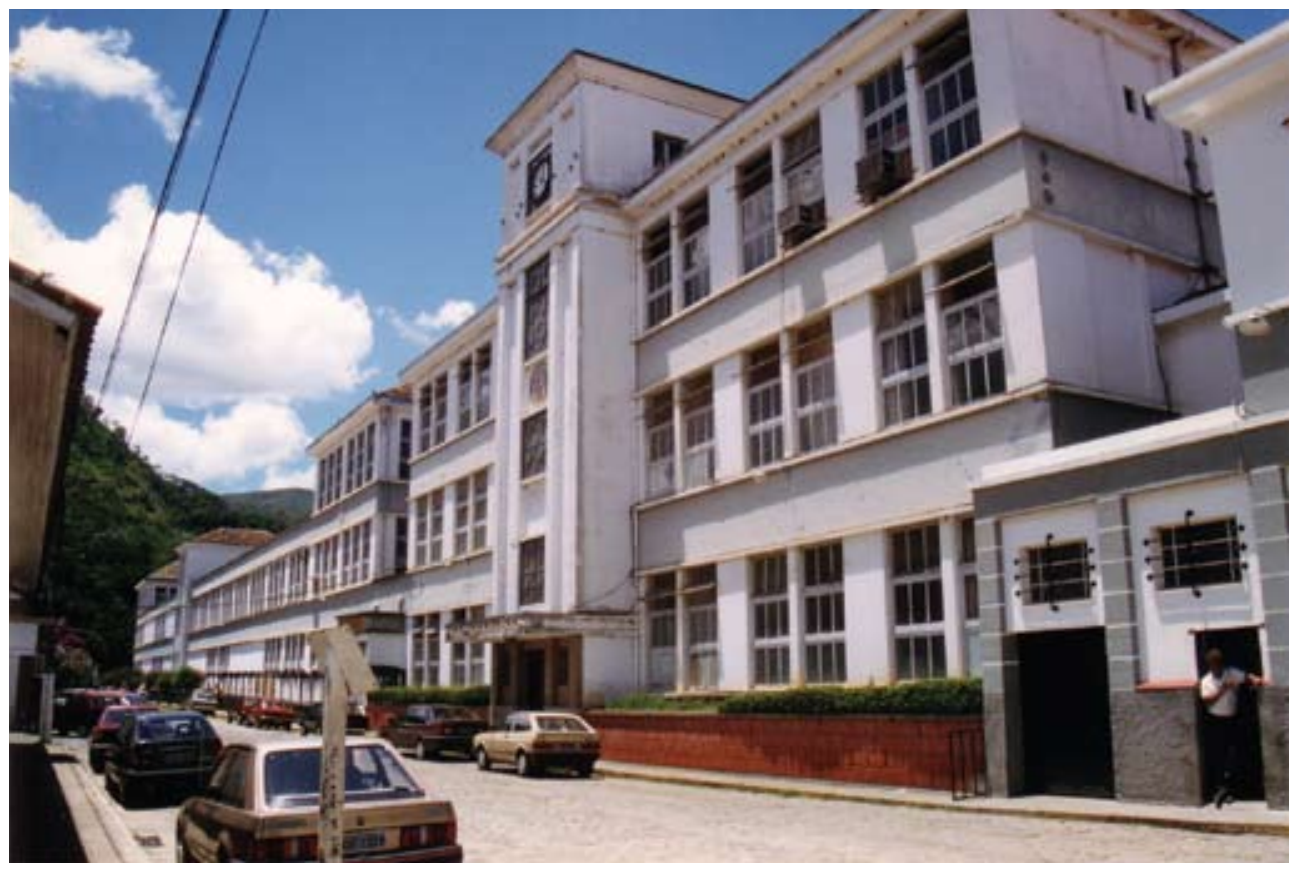

33. A fábrica situava-se em área rural a uma distância de 11 quilômetros da cidade de Caxias do Sul. Junto às suas instalações industriais, criou-se Galópolis, um núcleo fabril, com mais de cem casas, igreja, escola, cooperativa de consumo, farmácia, consultório médico, clube e cinema.

34. Cf. Duminiense Paranhos Antunes (1950, p. 279280).

Figura 10 - Fábrica Ypu, em Nova Friburgo (RJ). Fotografia de Philip Gunn, 1998.

Em Caxias do Sul no estado do Rio Grande do Sul, o edifício da Metalúrgica Eberle incorpora uma torre central cuja composição remete ao gosto déco. No mesmo município, o núcleo fabril erguido pelo Lanifício São Pedro (hoje Cotegal), de Galópolis, reúne vários exemplares arquitetônicos que empregam composição ou detalhes associados à estética art déco, incluindo a igreja (composição volumétrica integrando prismas retangulares escalonados), o cinema (marquise e composição de fachada escalonada), e um conjunto reunindo moradias e espaços para comércio (ornatos escalonados) ${ }^{33}$ (Figuras 11 a 13). A igreja, construída em 1947 segundo projeto dos engenheiros civis Luiz F. de Lesegneur e Sady de Castro, despertou grande entusiasmo em um jornalista de Caxias do Sul, em 1950:

Verdadeiro padrão de arte cristã moderna, a monumental lgreja Matriz, testemunho perene da fé viva e da operosidade de uma população, fulgura por entre vetustas habitações e se arroja para o alto desafiando a beleza panorâmica dos montes de Galópolis. É ela a última palavra da arte cristã moderna levada ao fastígio do gosto pelo belo em terras sulinas do pais $^{34}$

Em Rosário do Sul, também no estado do Rio Grande do Sul, a hospedaria para funcionários solteiros, criada pela Companhia Swift do Brasil, incorporou pequenos detalhes de gosto déco, como a lareira do salão principal e o tratamento do volume que marca a entrada para o salão (Figura 14).

Nas minas de Butiá, nesse mesmo estado, o núcleo residencial criado pelo Consórcio Administrativo de Empresas de Mineração (Cadem), incluiu duas

Annals of Museu Paulista. v. 16. n.2. July - Dec. 2008. 

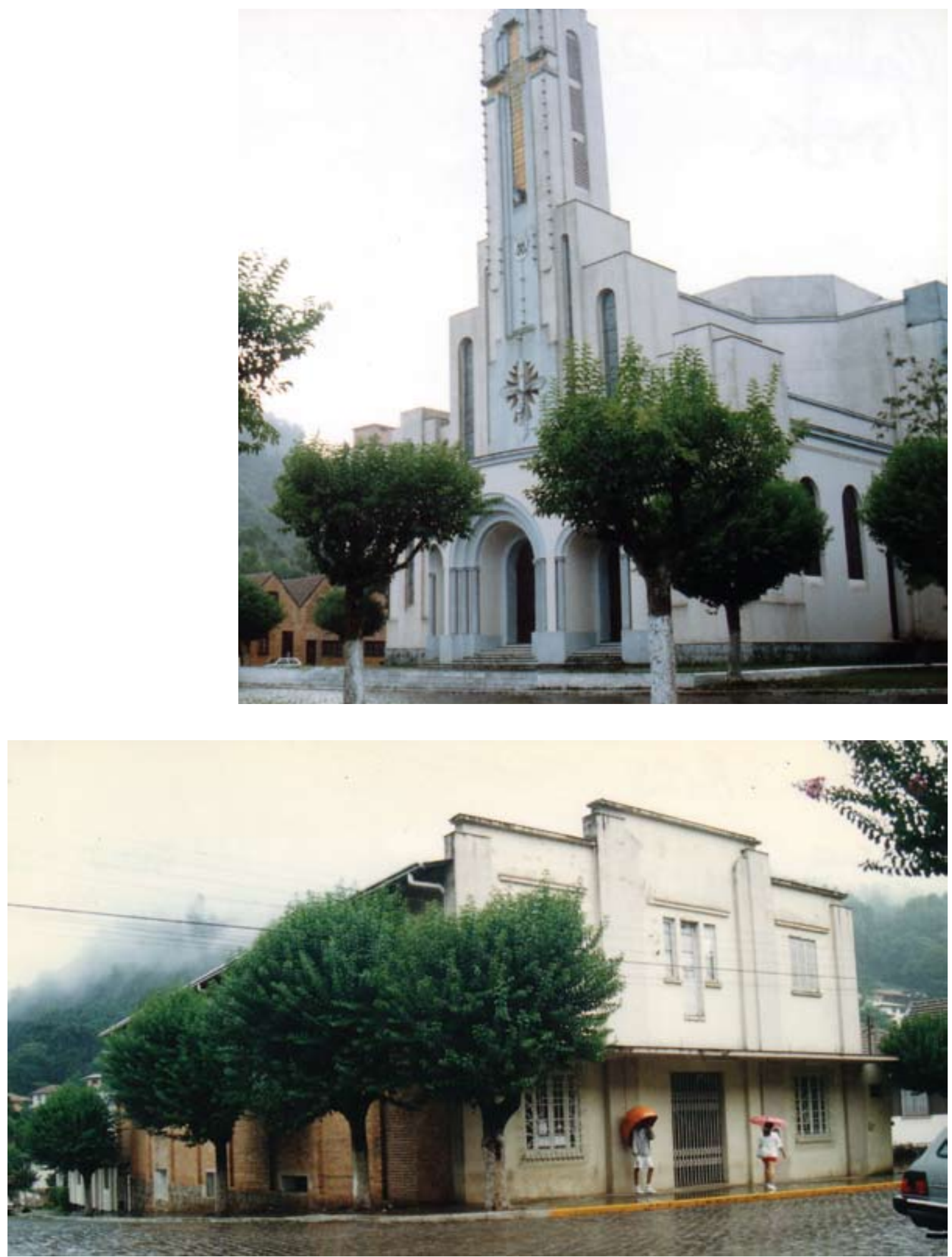

Figuras 11 e 12 - Igreja e cinema no núcleo fabril de Galópolis, em Caxias (RS). Fotografias de Philip Gunn, 1997. 


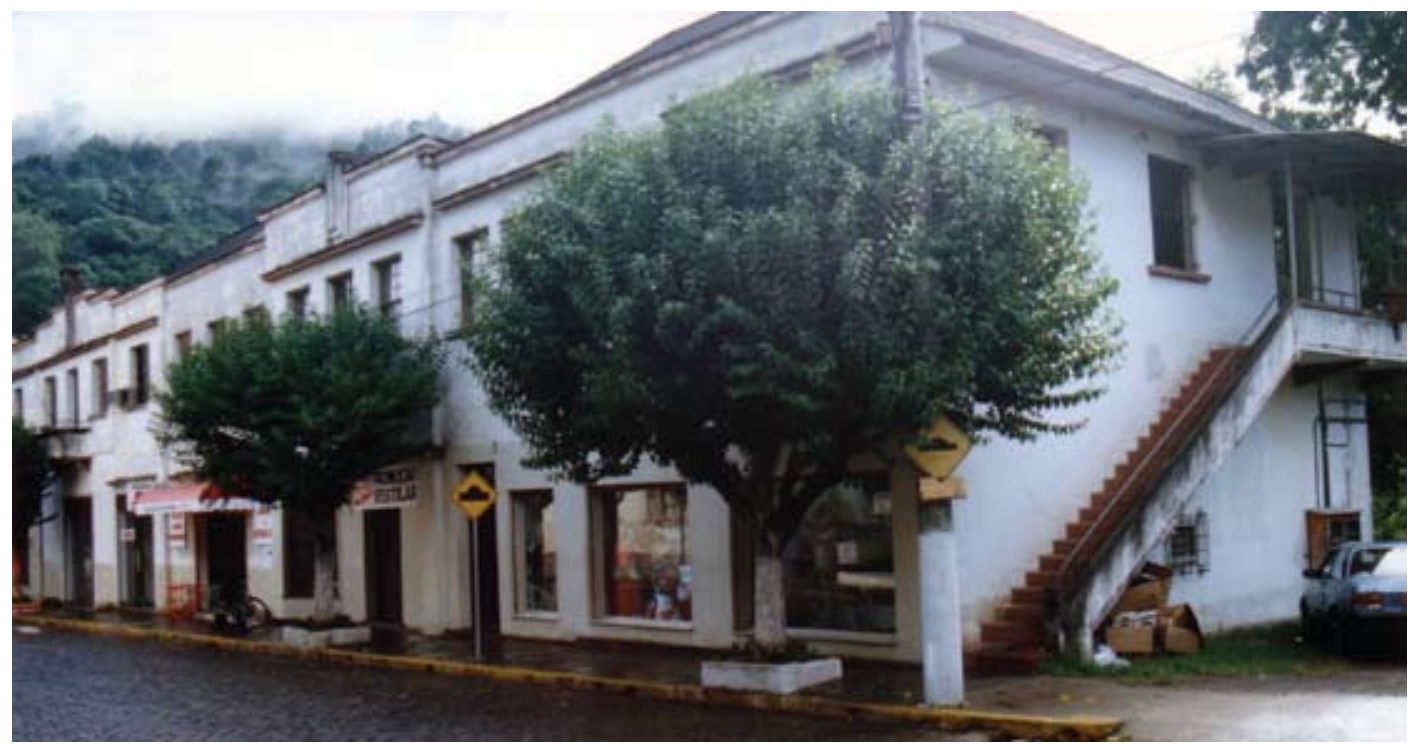

Figura 13 - Conjunto reunindo moradias e espaços para comércio erguidos pelo Lanifício São Pedro de Galópolis, no núcleo fabril de Galópolis, em Caxias (RS). Fotografia de Philip Gunn, 1997.

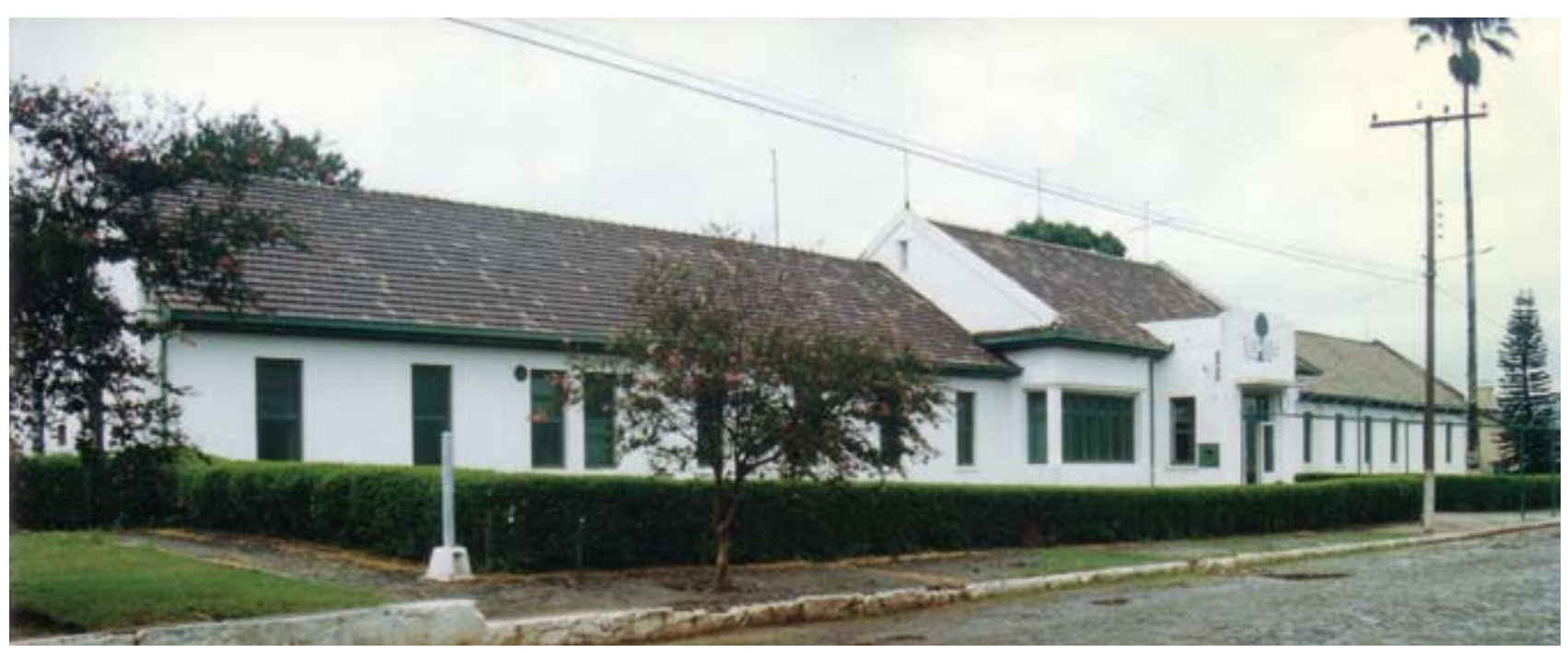

Figura 14 - Hospedaria da Companhia Swift do Brasil, em Rosário do Sul (RS). Fotografia de Philip Gunn, 1997.

construções com vocabulário art déco: o Cine Teatro Butiá (inaugurado em 1943) e o Clube Butiá (inaugurado em 1944). Ambos os prédios incoporam amplamente componentes do repertório formal art déco: aberturas em forma de escotilha nas paredes e portas; marquises; composição de fachada escalonada; vitrais; e frisos verticais e horizontais. Em ambos os casos, a composição enfatiza os acessos principais: no clube, ele é demarcado por marquise, pilastras, escotilha e elevação

Annals of Museu Paulista. v. 16. n.2. July - Dec. 2008. 
da platibanda; no cinema, por toda uma composição simétrica da fachada, centralizada pela porta implantada em plano avançado de alvenaria, sobre a qual sucessivamente foram dispostos marquise, óculo e uma elevação da platibanda (Figuras 15 e 16).
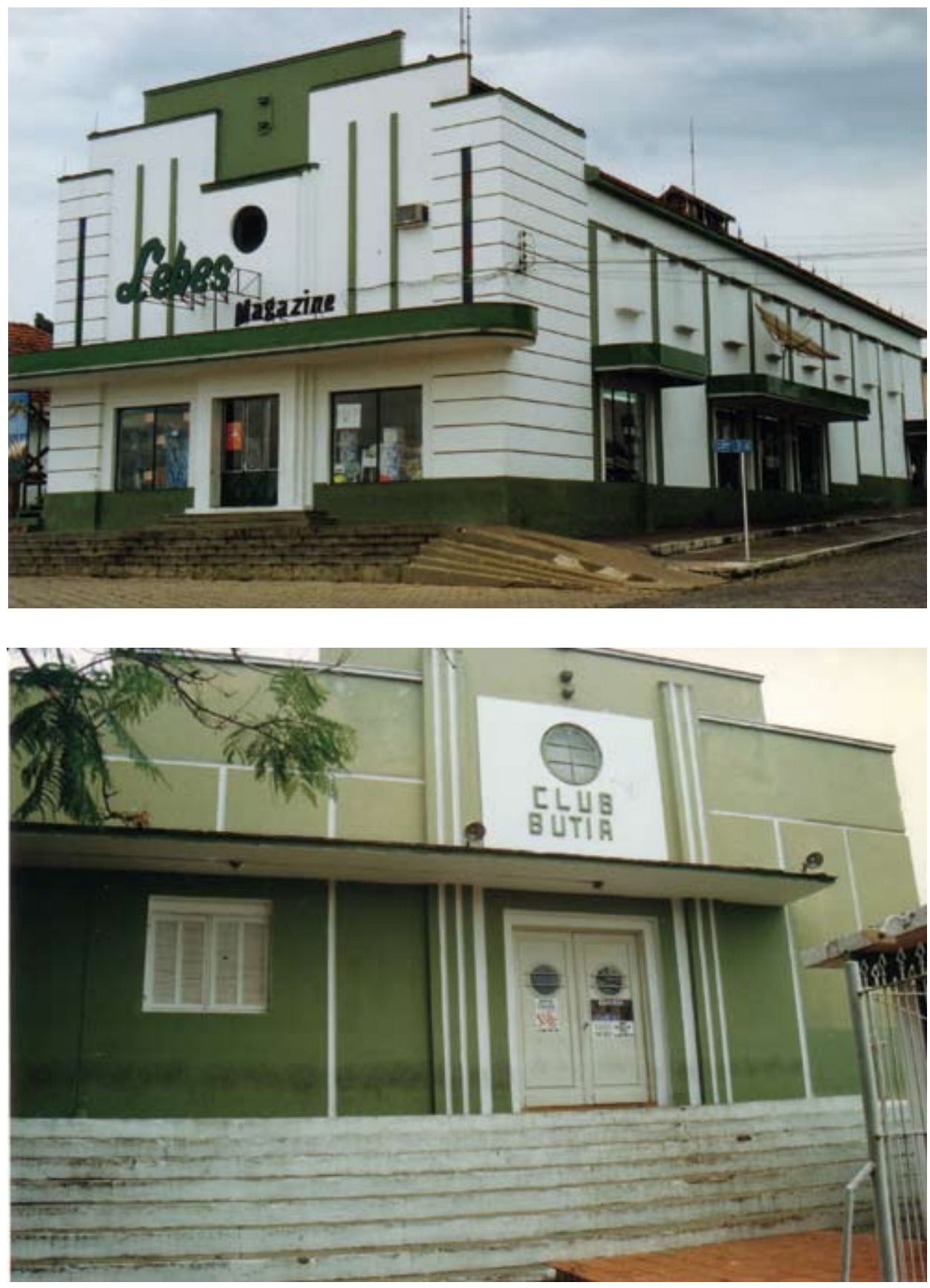

Figuras 15 e 16 - Cinema (inaugurado em 1943) e Clube (inaugurado em 1944), construídos pela CADEM, em Butiá (RS). Fotografias de Philip Gunn, 1997. 
Em Brusque, Santa Catarina, alguns prédios fabris da Fábrica de Tecidos Renaux adotam formas e ornatos típicos do vocabulário de arquitetura do Art déco, tais como marquises, paredes com quinas arredondadas e platibandas com formas escalonadas (Figura 17).

Na Paraíba, remete à estética do Art déco a construção erguida pela Companhia de Tecidos Paraibana, na cidade de Santa Rita, para abrigar a escola de sua vila operária ${ }^{35}$. $\bigcirc$ prédio, composto por um único bloco regular de geometria pura, sobre o qual se eleva outro volume simples em que há um relógio, aproxima-se da linguagem do estilo internacional de arquitetura moderna. Nele o gosto déco é denunciado pelo ornato em relevo com desenho em ziguezague, que compõe uma faixa percorrendo toda a platibanda nos dois volumes. $\bigcirc$ clube construído por esta fábrica em 1925 - com frontão elevado e ornatos circulares - também denuncia um leve viés déco (Figura 18).

No Ceará, as fachadas das casas da vila operária erguida pela Fábrica de Tecidos São José, em Fortaleza, adotam, nos seus frontões, detalhes decorativos simples, de linhagem déco, com formas geométricas escalonadas ${ }^{36}$ (Figura 19).

Em Natal, as fachadas das casas da vila operária da Fábrica de Tecidos Jovino Barreto têm desenhos ornamentais geométricos, de inspiração déco, dispostos de modo a enfatizar o escalonamento, decorrente da implantação em terreno com forte declividade (Figura 20).

A igreja do núcleo fabril criado pela Fábrica da Passagem, em Neópolis (SE), remete ao Art déco, com sua fachada marcada por um delicado
35. Esta fábrica, fundada no fim do século XIX, criou uma vila operária, situada na periferia da cidade de Santa Rita, com 245 casas, praça, escola, posto médico e clube.

36. Criada em 1926, a Fábrica de Tecidos São José ergueu, no bairro de Jacarecanga, uma grande vila operária, reunindo 247 habitações (casas e apartamentos), escola primária, restaurante, praça, escola de ofício, clube e campos de esportes. A vila foi construída em três etapas, no período entre 1928 e 1945 : em 1928 foram edificadas 6 casas para mestres (demolidas posteriormente); em 1933 foram erguidas 80 moradias e em 1945 outras 167 habitações. Ver Margarida J. F. de Salles Andrade(1990).

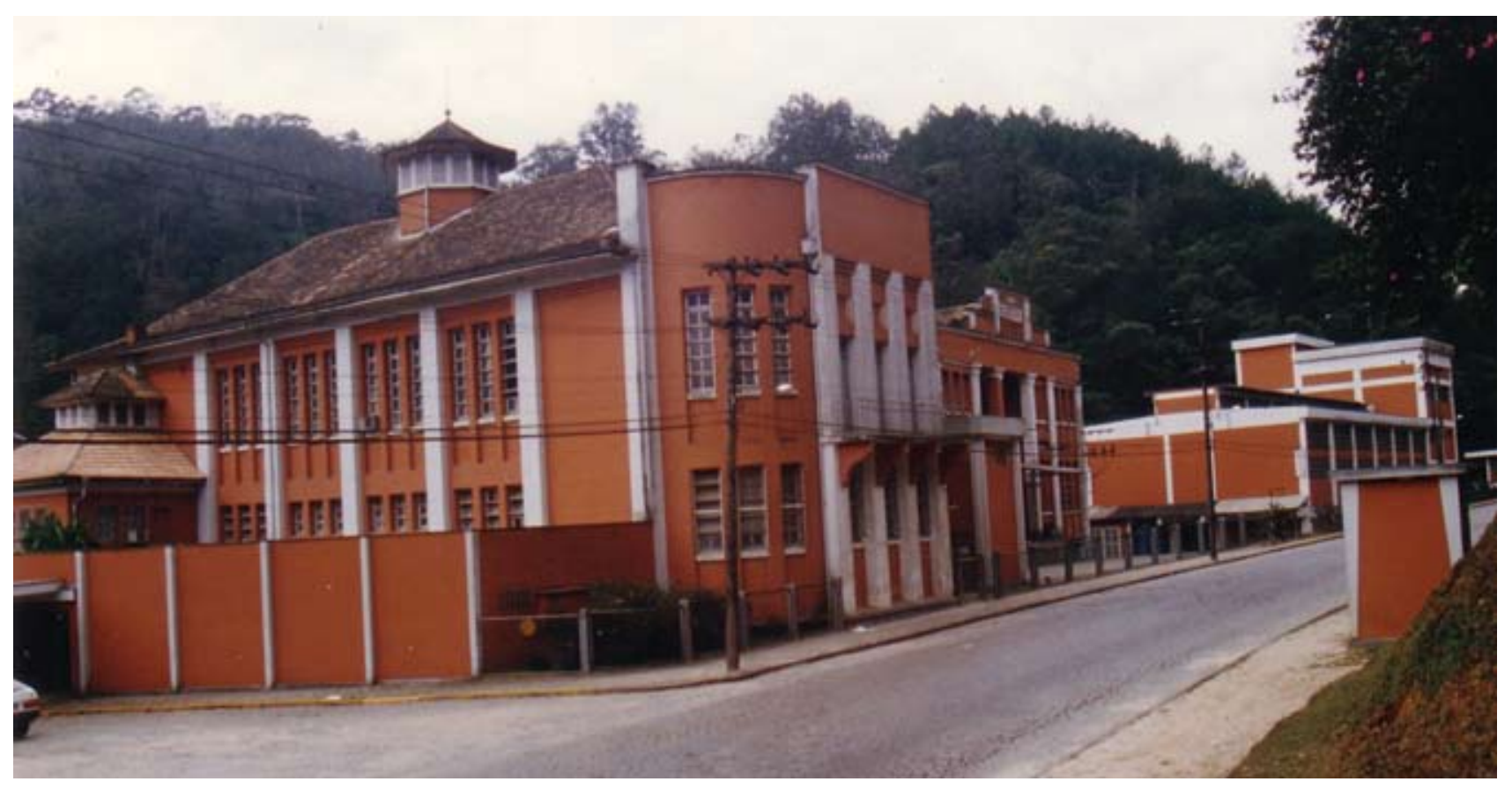

Figura 17 - Prédio da Fábrica de Tecidos Renaux, em Brusque (SC). Fotografia de Philip Gunn, 1997. 


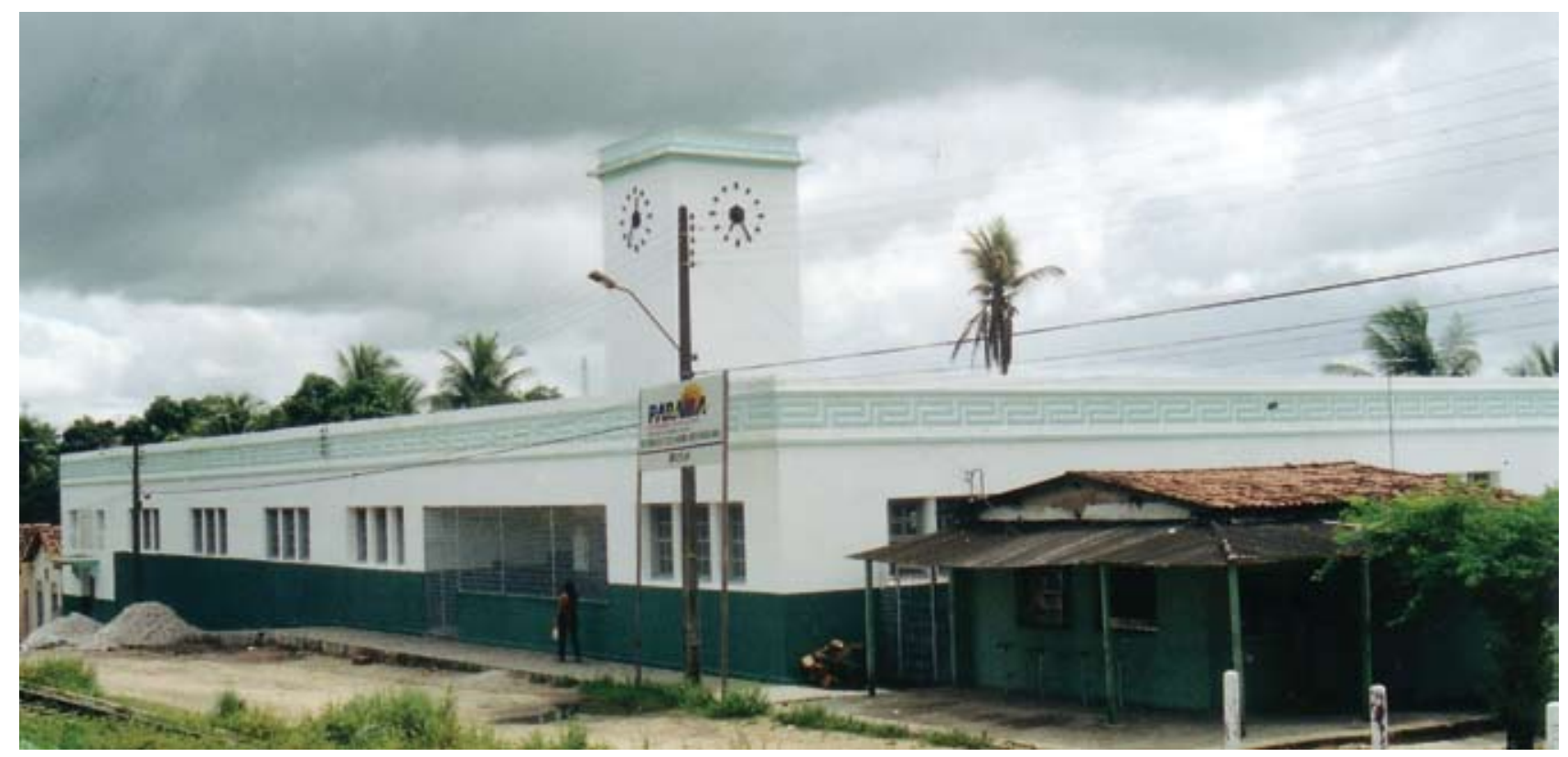

Figura 18 - Escola e clube (construído em 1925) erguidos pela Companhia de Tecidos Paraibana, em Santa Rita (PB). Fotografia de Philip Gunn, 2002.

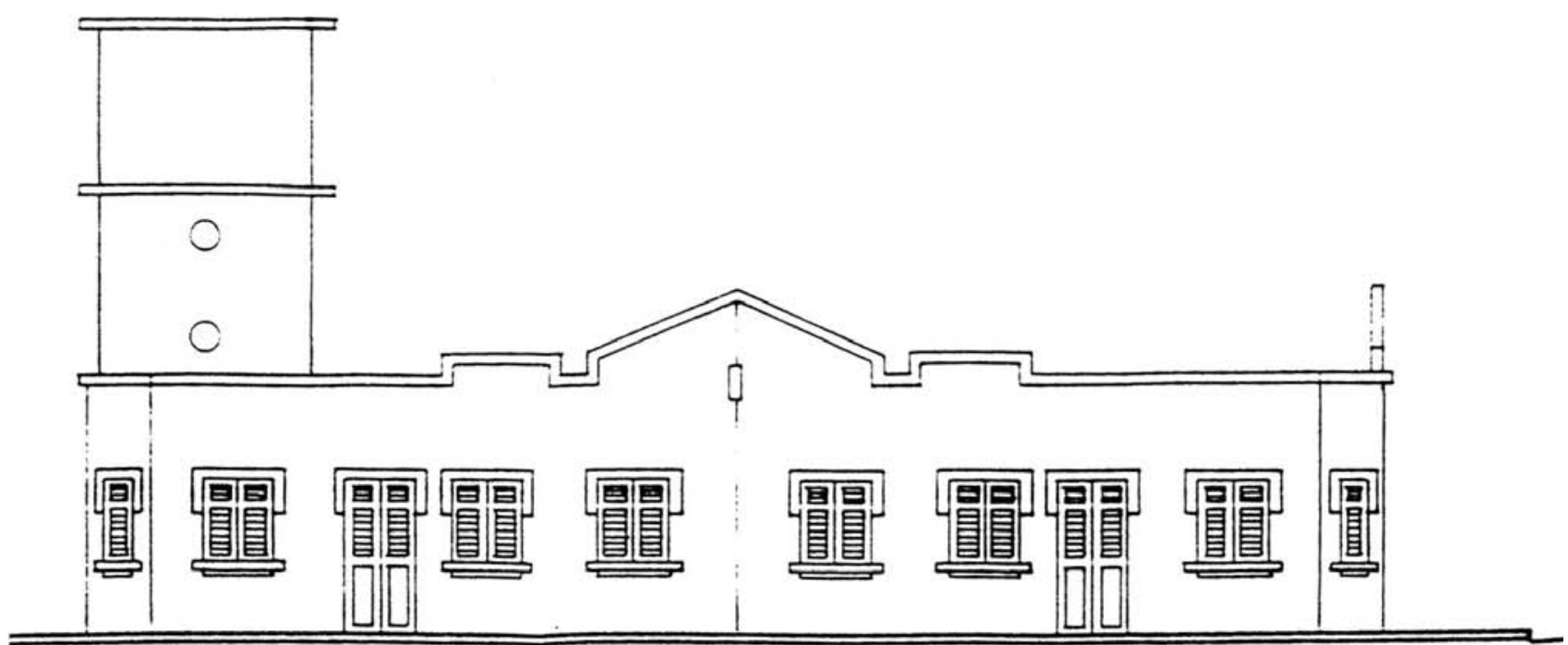

Figura 19 - Fachadas de casas da Vila São José, erguida entre 1933 e 1945, pela Fábrica de Tecidos São José, no bairro de Jacarecanga, em Fortaleza (CE). ANDRADE, 1990, p.192. 


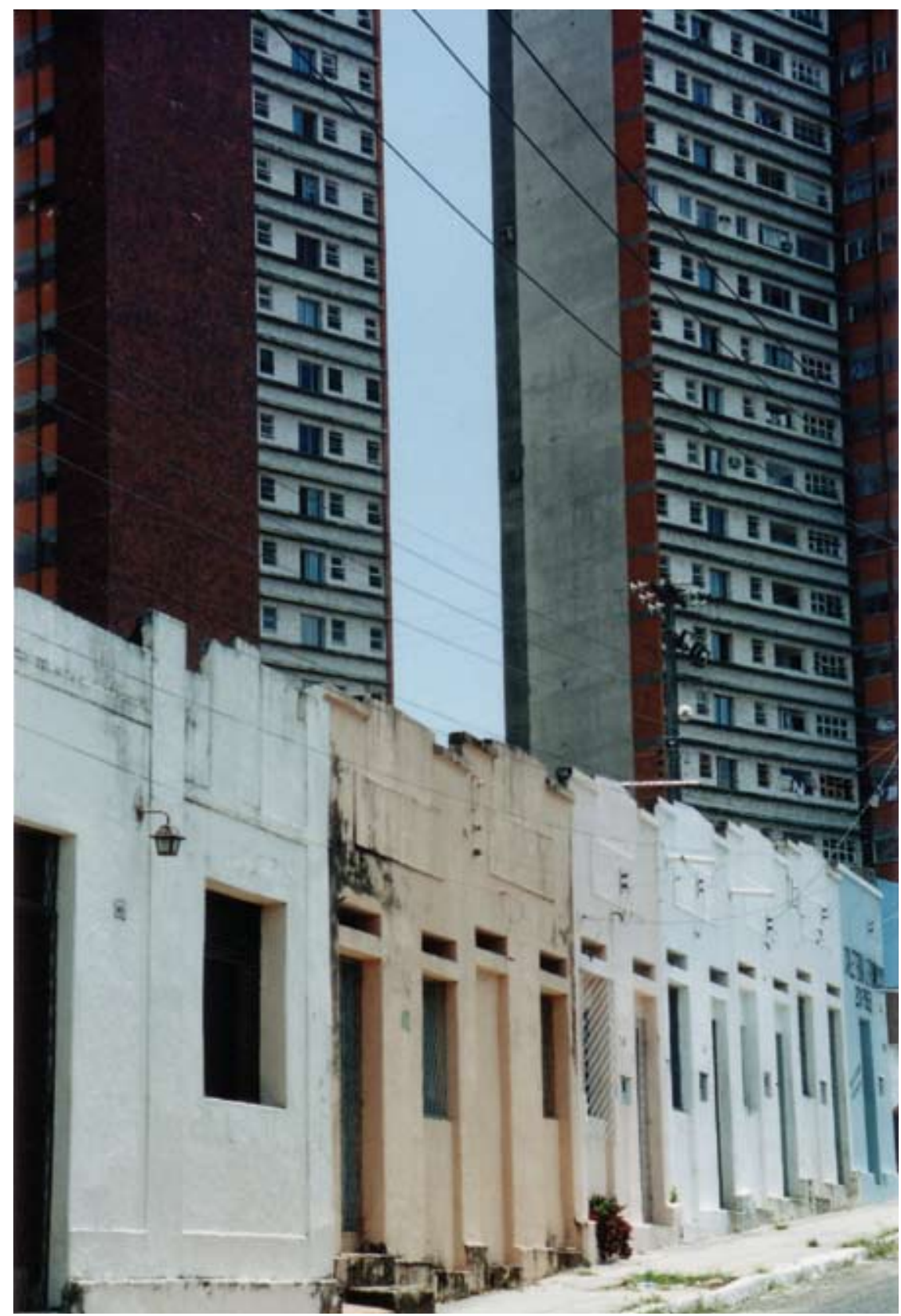

37. Erguido entre 1907 e a década de 1950 , este núcleo fabril, além da fábrica, reuniu 270 moradias, armazém de abastecimento, escola, capela, clube e campo de futebol.

Figura 20 - Casas construídas pela Fábrica de Tecidos Jovino Barreto, em Natal (RN). Fotografia de Philip Gunn, 2000.

escalonamento que culmina numa torre central. A composição das fachadas do cinema incorpora elementos clássicos - platibanda, frontão e pilastras adaptados à linguagem déco. As fachadas de algumas das casas deste núcleo têm elementos ornamentais geométricos em alto relevo, de cunho art déco ${ }^{37}$ (Figuras 21 e 22). 
Já em Salvador, também remetem ao estilo algumas casas da vila operária da Fábrica de Tecidos São Brás, com suas platibandas ornamentadas com motivos geométricos ${ }^{38}$ (Figura 23).

Em Pernambuco, o vocabulário déco surge nas instalações da Fábrica Peixe, em Pesqueira - com sua sucessão de frontões escalonados - e em alguns
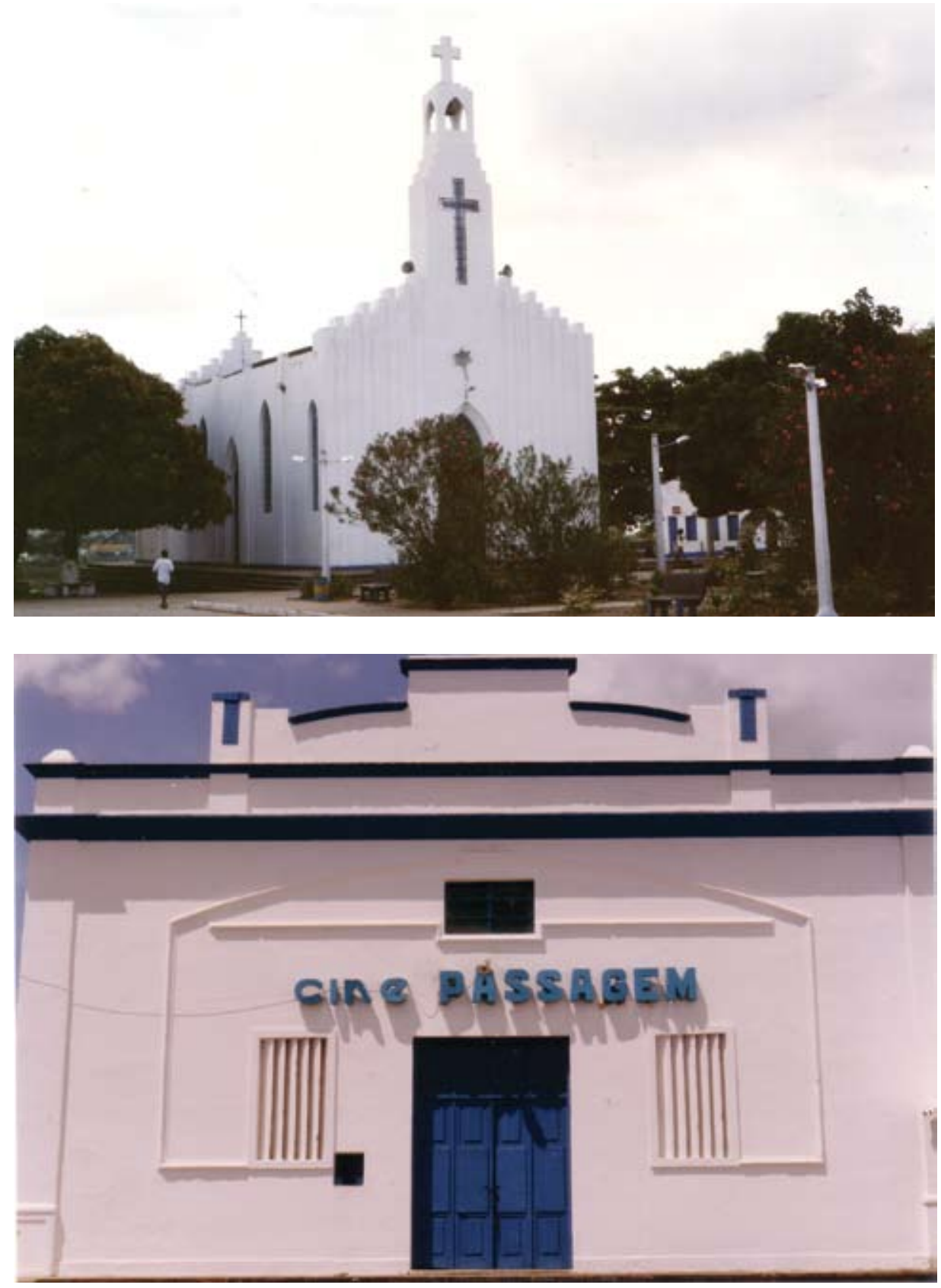

Figuras 21 e 22 - Igreja e cinema construídos pela Fábrica da Passagem, em Neópolis (SE). Fotografias de Philip Gunn, 1995. 
grupos de moradias no núcleo fabril de Paulista ${ }^{39}$ - com fachadas dotadas de ornatos de forma geométrica e tendo seus limites assinalados por pilastras de forma escalonada (Figuras 24 e 25).

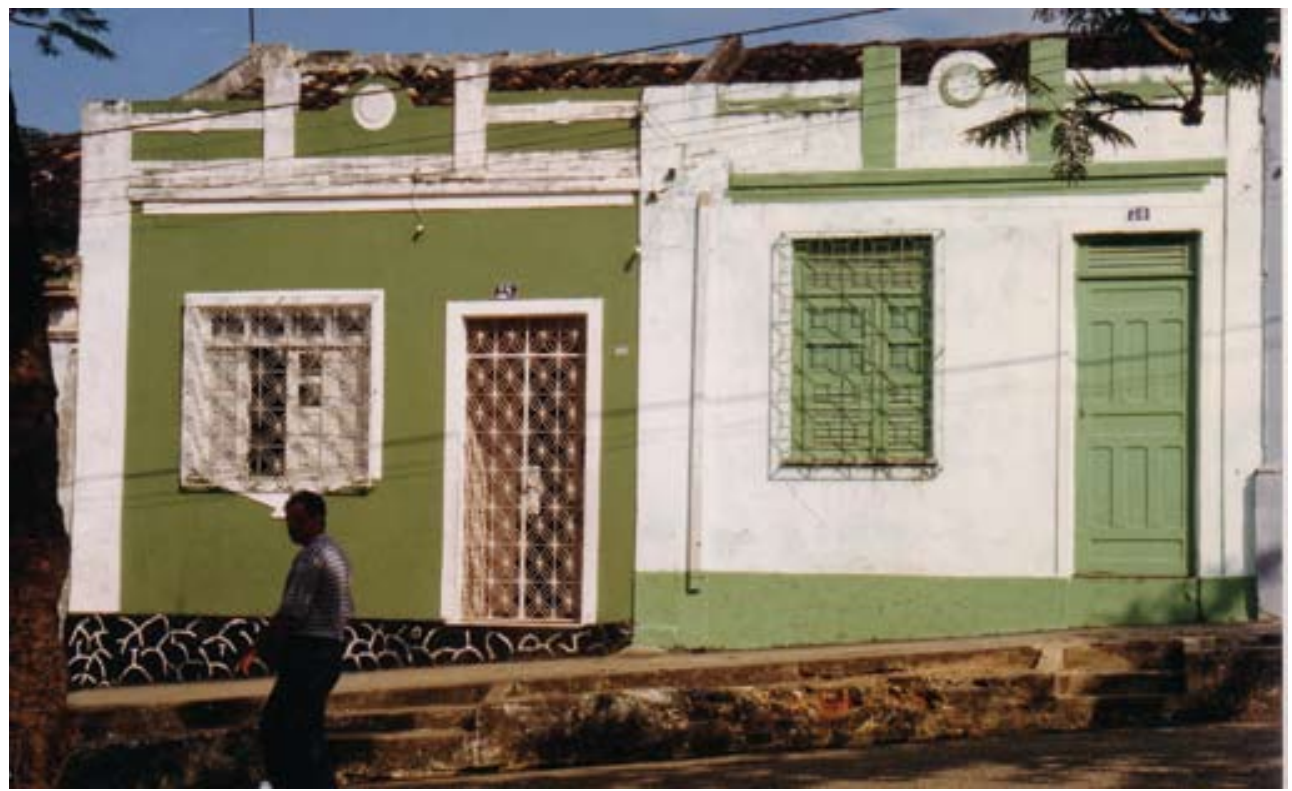

Figura 23 - Casas da vila operária da Fábrica de Tecidos São Brás, em Salvador (BA). Fotografia de Philip Gunn, 1998.

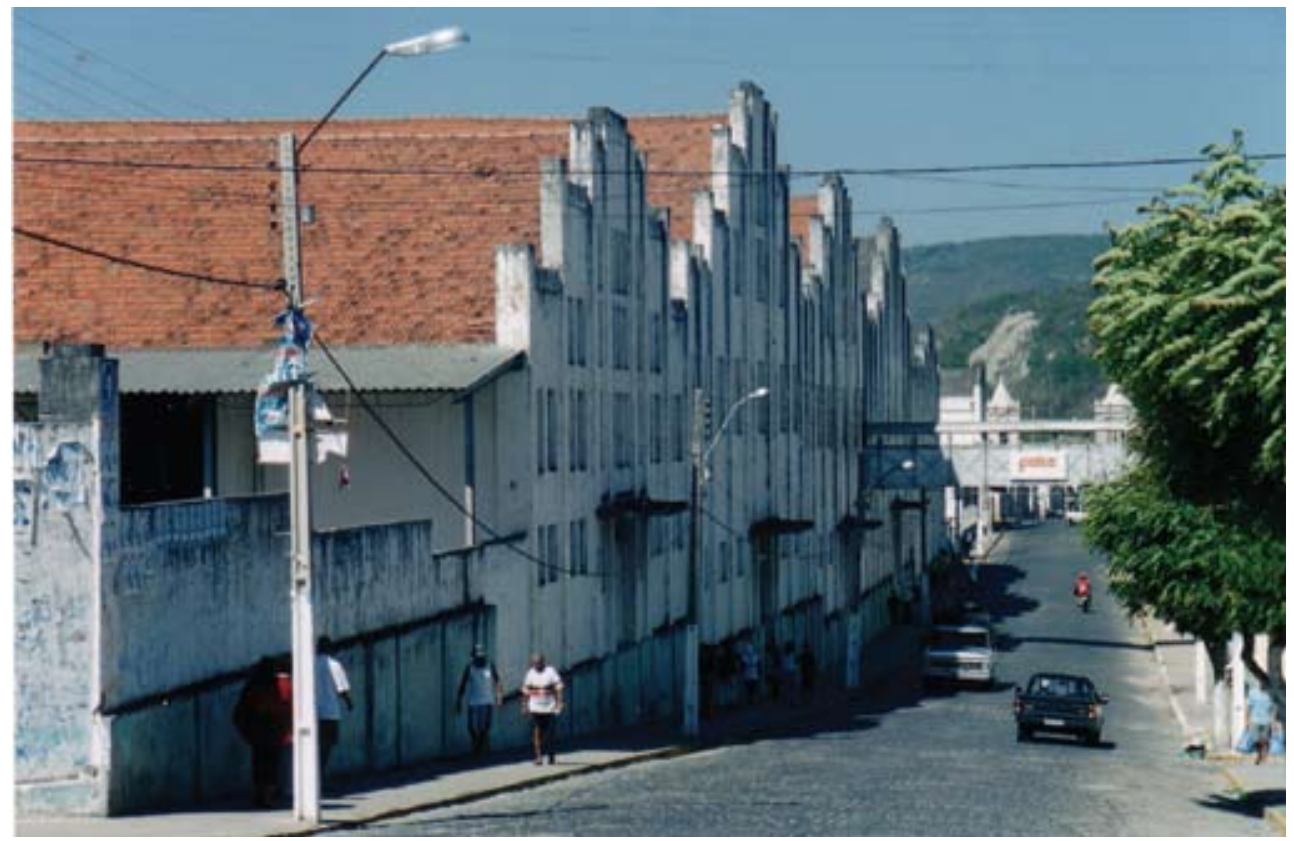

Figura 24 - Fábrica Peixe em Pesqueira (PE). Fotografia de Philip Gunn, 2003.
38. Além de casas, esta vila operária tinha escola, creche e posto de saúde.

39 Grande núcleo fabril que abrigou duas fábricas têxteis da família Lundgren - proprietária das Casas Pernambucanas -, Paulista contou com cerca de seis mil casas, porto e ferrovia particulares, cerâmica, atividades agrícolas, serviço próprio de abastecimento d'água $\mathrm{e}$ energia elétrica, igreja, feira, parque, cinema, hospital, teatro, escola, clube e campos de futebol. 
40. Fundada em 1895 no bairro de Apipucos, no Recife, a fábrica de tecidos da Macaxeira, foi adquirida em 1925 pela Othon Bezerra de Mello S. A., que empreendeu a construção de uma vila operária durante as décadas de 1930 e 1940. Em 1951, publicação do Serviço Social Contra o Mocambo indicava um total de 666 moradias construídas nesta vila. O empreendimento reuniu ainda escola, igreja clube, cinema, e posto médico e dentário.
Outra expressão da estética déco em Pernanbuco é o clube construído na vila operária do Cotonifício Othon Bezerra de Mello, no Recife, com fachada dotada de frontão cujo escalonamento é assinalado pela altura das pilastras, pela forma da platibanda, pelo desenho do letreiro em alto relevo e por vãos em forma hexagonal, com grades cujo desenho se compõe de formas geométricas vazadas ou fechadas ${ }^{40}$ (Figura 26).

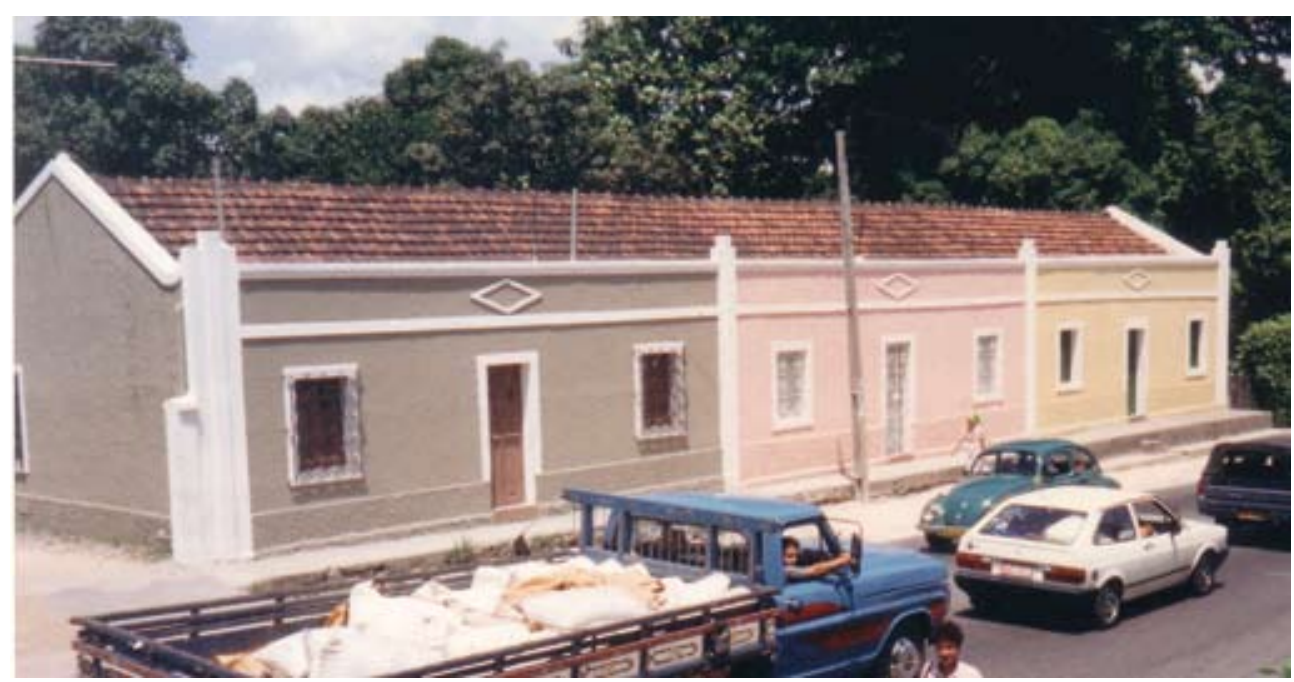

Figura 25 - Casas em Paulista (PE). Fotografia de Philip Gunn, 1995.

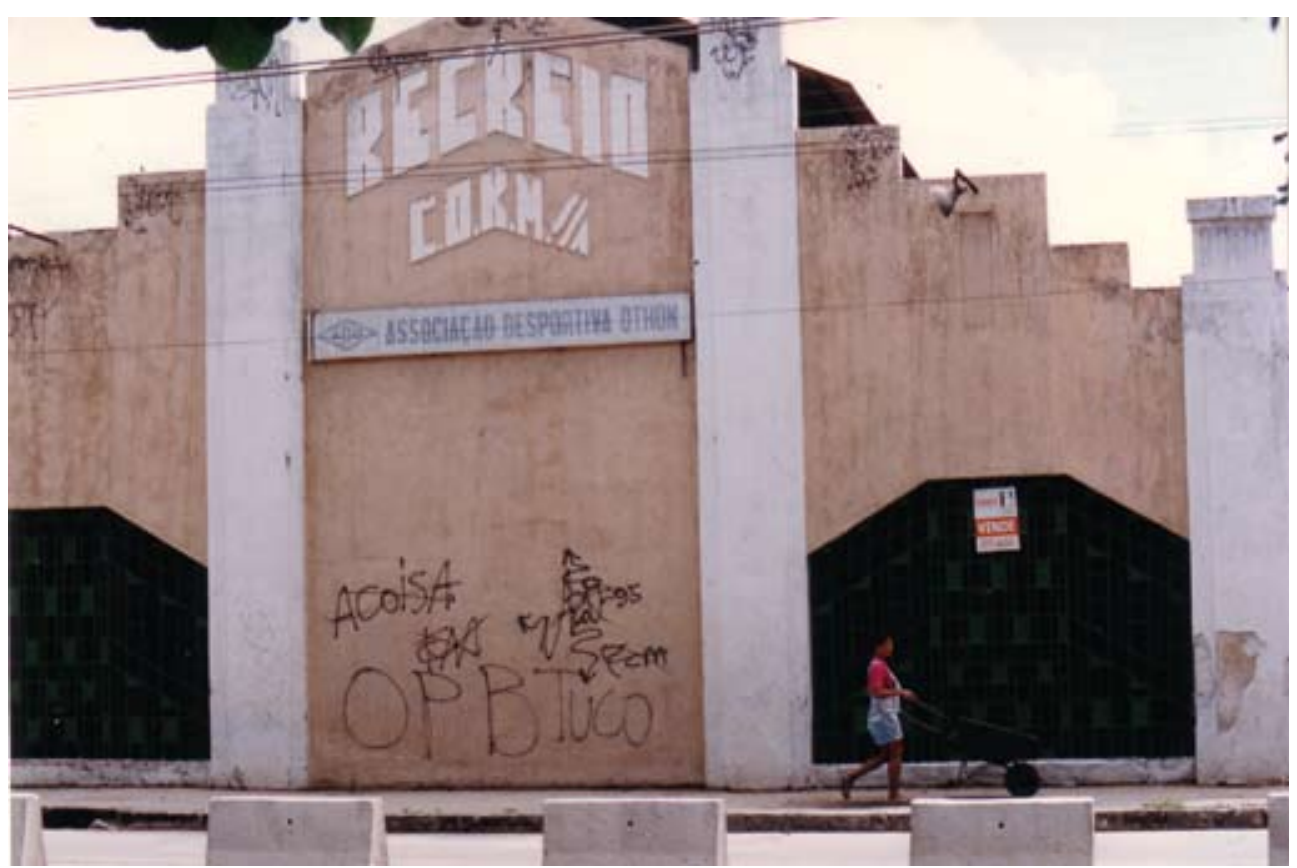

Figura 26 - Clube construído pelo Cotonifício Othon Bezerra de Mello, do Grupo Othon, no bairro da Apipucos, Recife (PE). Fotografia de Philip Gunn, 2003. 
Grande parte das edificações ligadas a indústrias assim como alguns dos mais expressivos prédios fabris que adotam vocabulário art déco, identificadas durante pesquisa de campo, concentra-se no estado de São Paulo. Aí, elementos do repertório formal art déco assinalam as fachadas das casas da Vila Boyes, em Piracicaba - delimitadas por duas pilastras arrematadas por ornatos escalonados e dotadas de platibanda também escalonada ${ }^{41}$ (Figuras 27 e 28).
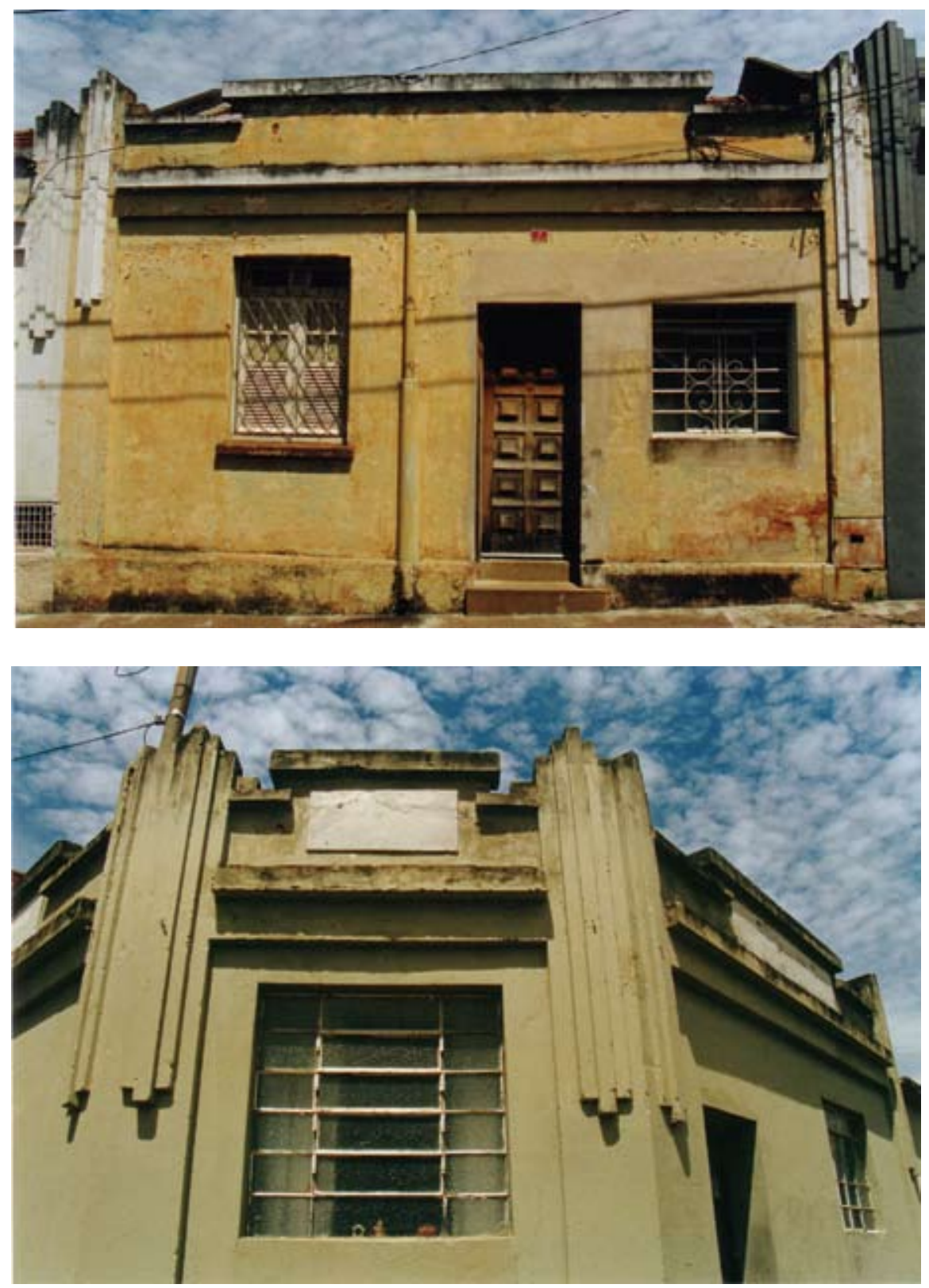

Figuras 27 e 28 - Casas da Vila Boyes, construída em 1938 pela Indústria Boyes, em Piracicaba (SP). Fotografias de Philip Gunn, 2002.
41. A Vila Boyes, situada no bairro Vila Progresso, contava com 104 casas, construídas em quatro ruas paralelas e uma pequena escola. São casas semelhantes, dispostas em blocos de 13 residências. As moradias tinham 60 metros quadrados, com sala, dois quartos, cozinha e sanitário, além de quintal. 
42. O núcleo fabril de Votorantim - que antes de converter-se em cidade, era distrito de Sorocaba - chegou a reunir cerca de 600 casas creche, escolas, clubes, igreja, cine-teatro, armazém de consumo, hospital e matadouro, além de serviços de abastecimento de água, esgotos e energia elétrica.

43. Em 1945, em área então pertencente ao município de São Roque, o Grupo Votorantim inaugurou a Companhia Brasileira de Alumínio, primeira empresa a fabricar esse produto no País. Junto à fábrica, criou o núcleo fabril da agora cidade de Alumínio, que reuniu cerca de 500 casas, escola, igreja, clube, hotel para engenheiros, hotel para técnicos, posto de saúde, cooperativa de consumo e escola Sesi.

44. A chamada Vila Argos Velha - primeira vila operária construída pela Argos em Jundiaí - reuniu 43 casas, situadas em três ruas paralelas, nas imediações da fábrica.

A linguagem art déco também está presente em alguns conjuntos de moradias erguidas nos anos 1930 e 1940 pela Fábrica de Estamparia e Alvejaria Votorantim, em Votorantim (dotadas de frontões escalonados e de ornatos estilizados em alto relevo), assim como no prédio do Hospital Santo Antônio (inaugurado em 1949), e na construção que concentra os escritórios da fábrica e o acesso para a área de produção ${ }^{42}$. $\bigcirc$ prédio dos escritórios tem uma composição volumétrica baseada em três prismas ortogonais, constituída por dois blocos horizontais, no centro do qual sobressai um volume que se eleva. A simetria orienta a volumetria e a composição da fachada. $\bigcirc$ volume central traz, no alto, o nome da empresa e um relógio; e, no térreo, o acesso aos escritórios. Grandes janelas de vidro integram a fachada, enfatizando a verticalidade do bloco central e a horizontalidade dos blocos laterais, estabelecendo contrastes com as superfícies de alvenaria e com as três portas sublinhadas por marquises. Esse prédio - com seus volumes cúbicos, seus amplos vãos envidraçados e suas paredes brancas - destaca-se dos galpões mais antigos, erguidos em tijolo aparente ainda no século XIX. São duas expressões marcantes de arquitetura industrial que, ao compor o mesmo conjunto, atestam a renovação da linguagem arquitetônica e da noção de modernidade construtiva no mundo fabril (Figuras 29 a 311 .

No núcleo fabril que deu origem à atual cidade de Alumínio, erguido pela Companhia Brasileira de Alumínio, também do Grupo Votorantim, algumas casas contam com fachadas dotadas de elementos decorativos associados à estética déco ${ }^{43}$ (Figura 32).

Já a vila operária erguida pela Companhia de Fiação e Tecelagem São Pedro, em Itu, foi acrescida, no período em estudo, de um clube e de uma escola dotados de marquises, pilastras de seção quadrada ou circular, basculantes, platibanda escalonada, mastros e paredes com quinas arredondadas - elementos do vocabulário art déco (Figura 33).

Em Jundiaí, alguns dos prédios fabris da Argos Industrial, e uma de suas vilas operárias, remetem à estética art déco, que se expressa não só na portaria da fábrica - com grandes vãos envidraçados em superfícies curvas -, como, também, em galpão dotado de detalhes ornamentais verticais que avançam sobre a platibanda, em formas escalonadas; e, ainda, em edifício com fachada dotada de grandes painéis de vidro intercalados com pilastras. Erguida pela fábrica junto a este último prédio, uma das vilas operárias adota uma composição semelhante, com pilastras definindo os limites da fachada de cada moradia $^{44}$ (Figuras 34 e 35).

Em fábricas construídas anteriormente, esforços de modernização das fachadas expressam-se, em alguns casos, pela incorporação de portarias de gosto déco. Este foi o caso das portarias da Fiação, Tecelagem e Estamparia Ypiranga Jafet (São Paulo, SP, fundada em 1893) e da Companhia de Fiação e Tecidos Santa Maria (Sorocaba, 1896) (Figuras 36 e 37). 


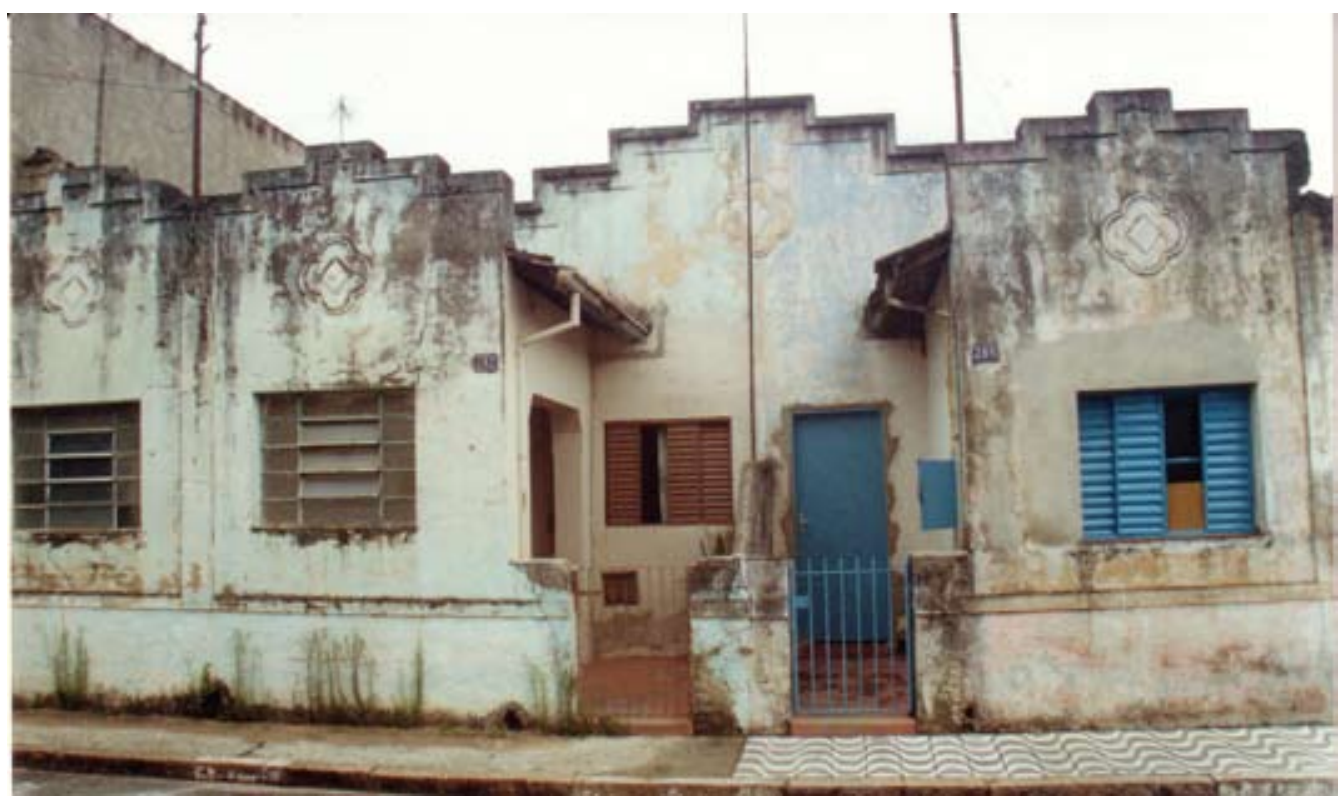

Figura 29 - Casas operárias erguidas pela Fábrica de Estamparia e Alvejaria Votorantim, do Grupo Votorantim, em Votorantim (SP). Fotografia de Philip Gunn, 2001.

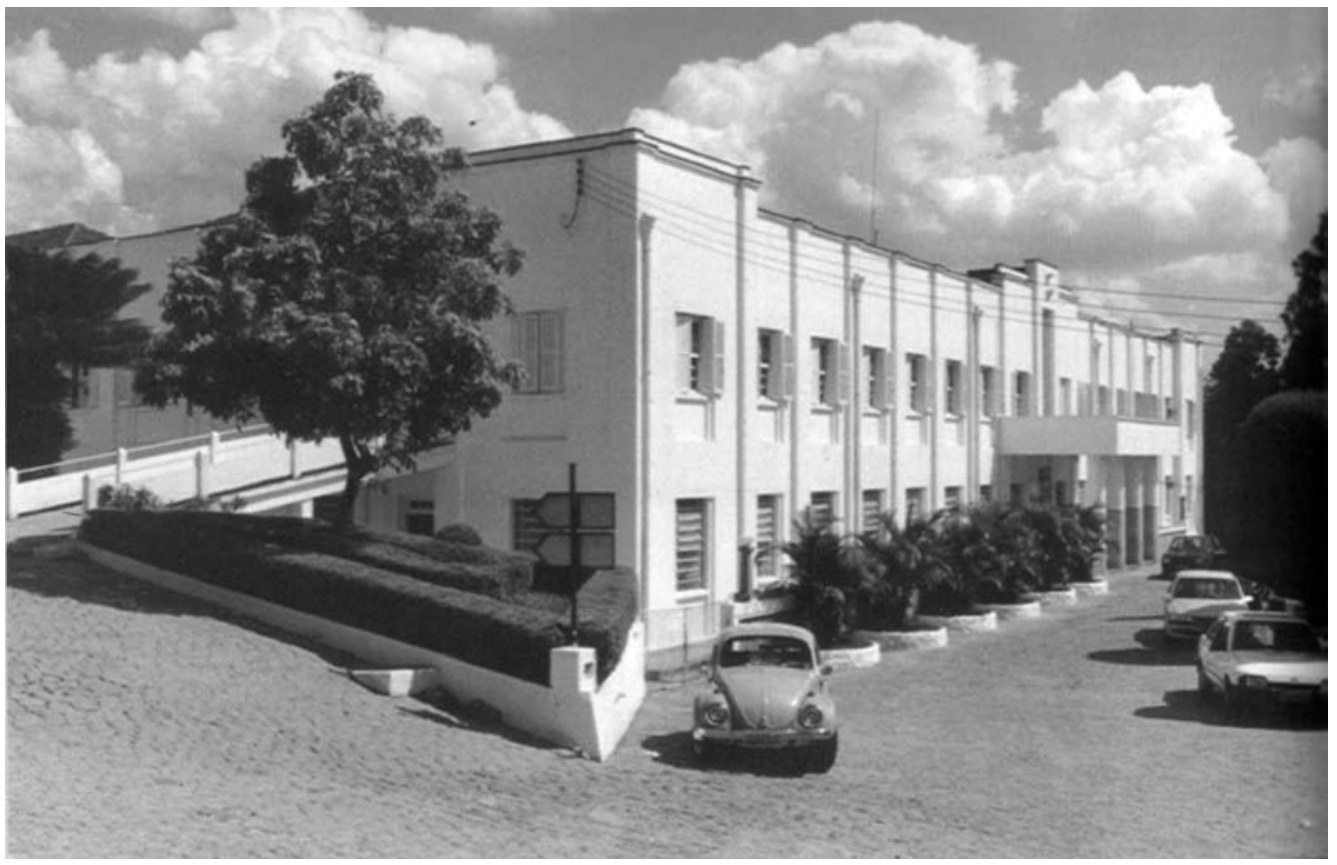

Figura 30 - Hospital, inaugurado em 1949 na Fábrica de Estamparia e Alvejaria Votorantim, do Grupo Votorantim, em Votorantim (SP). MARTINS, 2000, 88. 


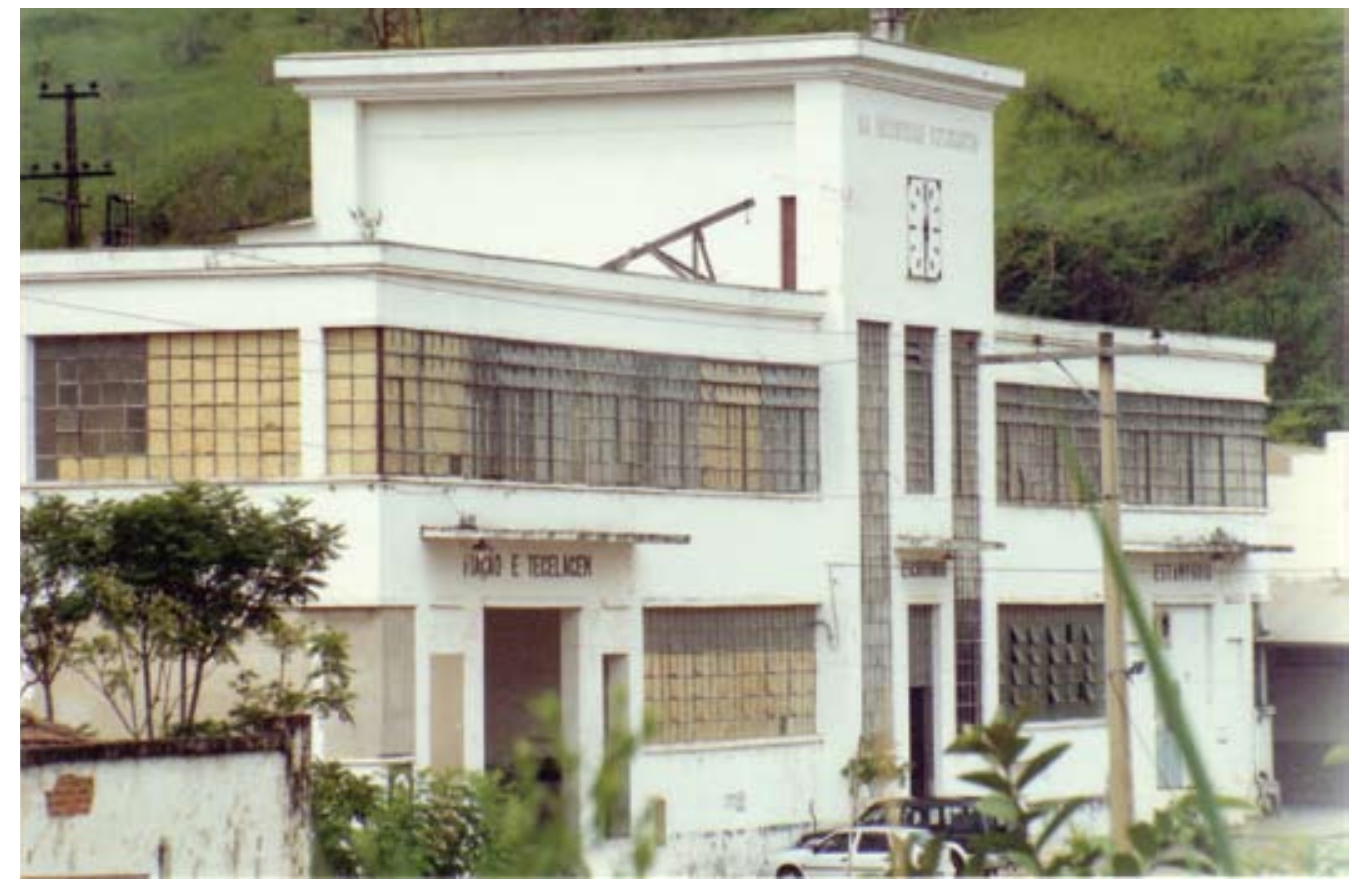

Figura 31 - Prédio da Fábrica de Estamparia e Alvejaria Votorantim, do Grupo Votorantim, em Votorantim (SP). Fotografia de Philip Gunn, 2001.

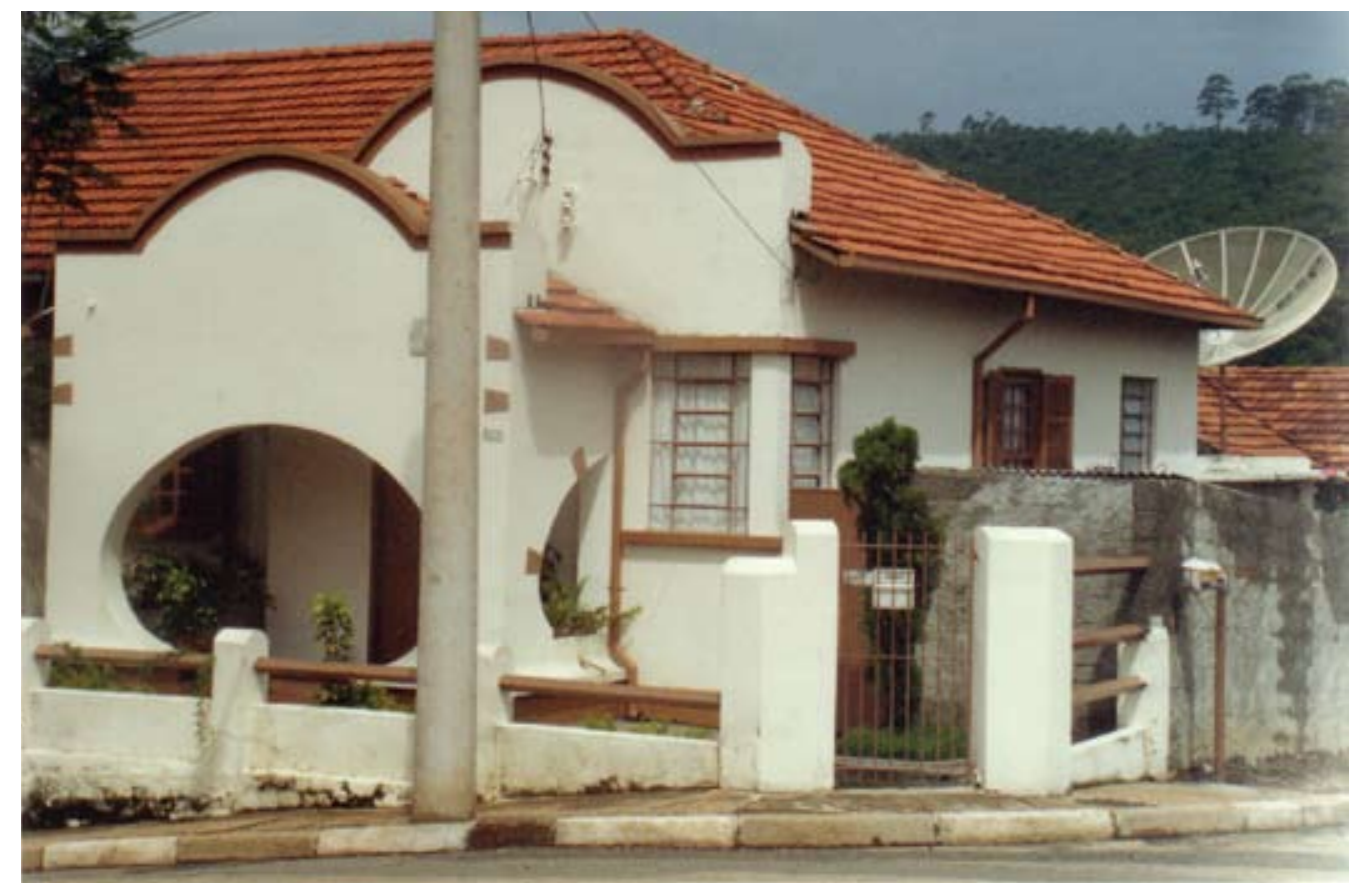

Figura 32 - Casa erguida na década de 1940 pela Companhia Brasileira de Alumínio, do Grupo Votorantim, em Alumínio (SP). Fotografia de Philip Gunn, 2001. 


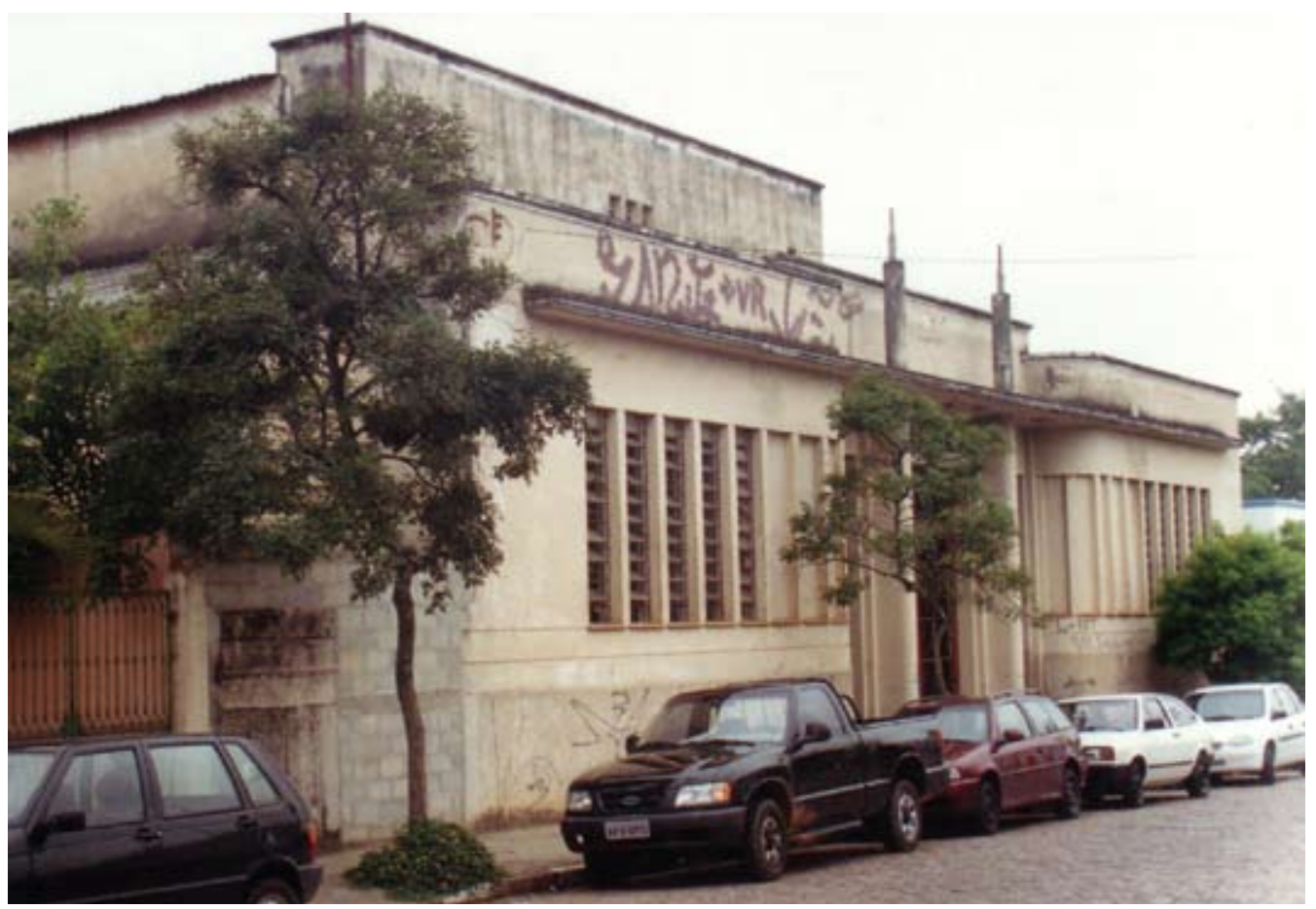

Figura 33 - Clube construído pela Companhia de Fiação e Tecelagem São Pedro, em Itu (SP). Fotografia de Philip Gunn, 2001.

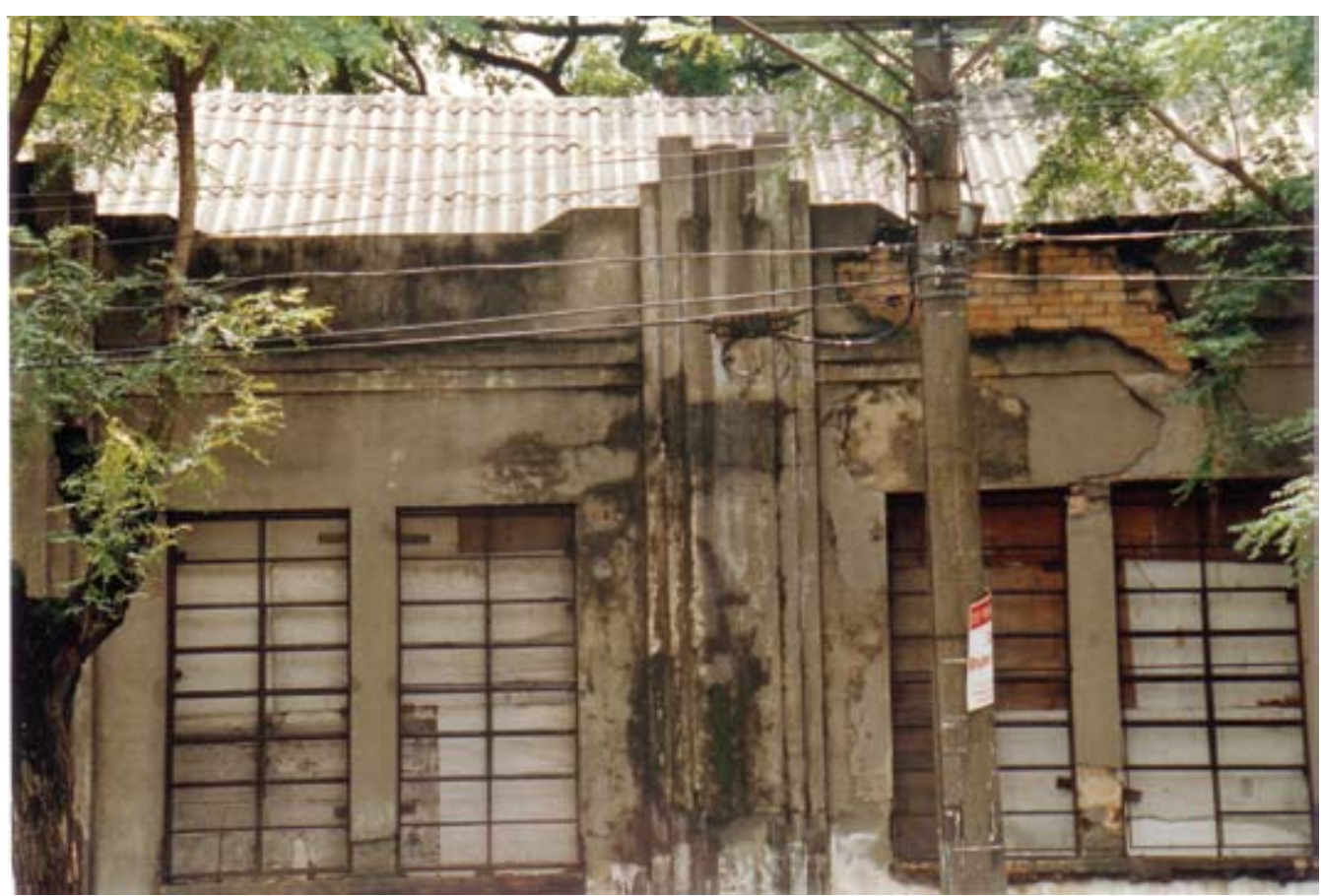

Figura 34 - Prédios da Argos Industrial, em Jundiaí (SP). Fotografia de Philip Gunn, 2002. 


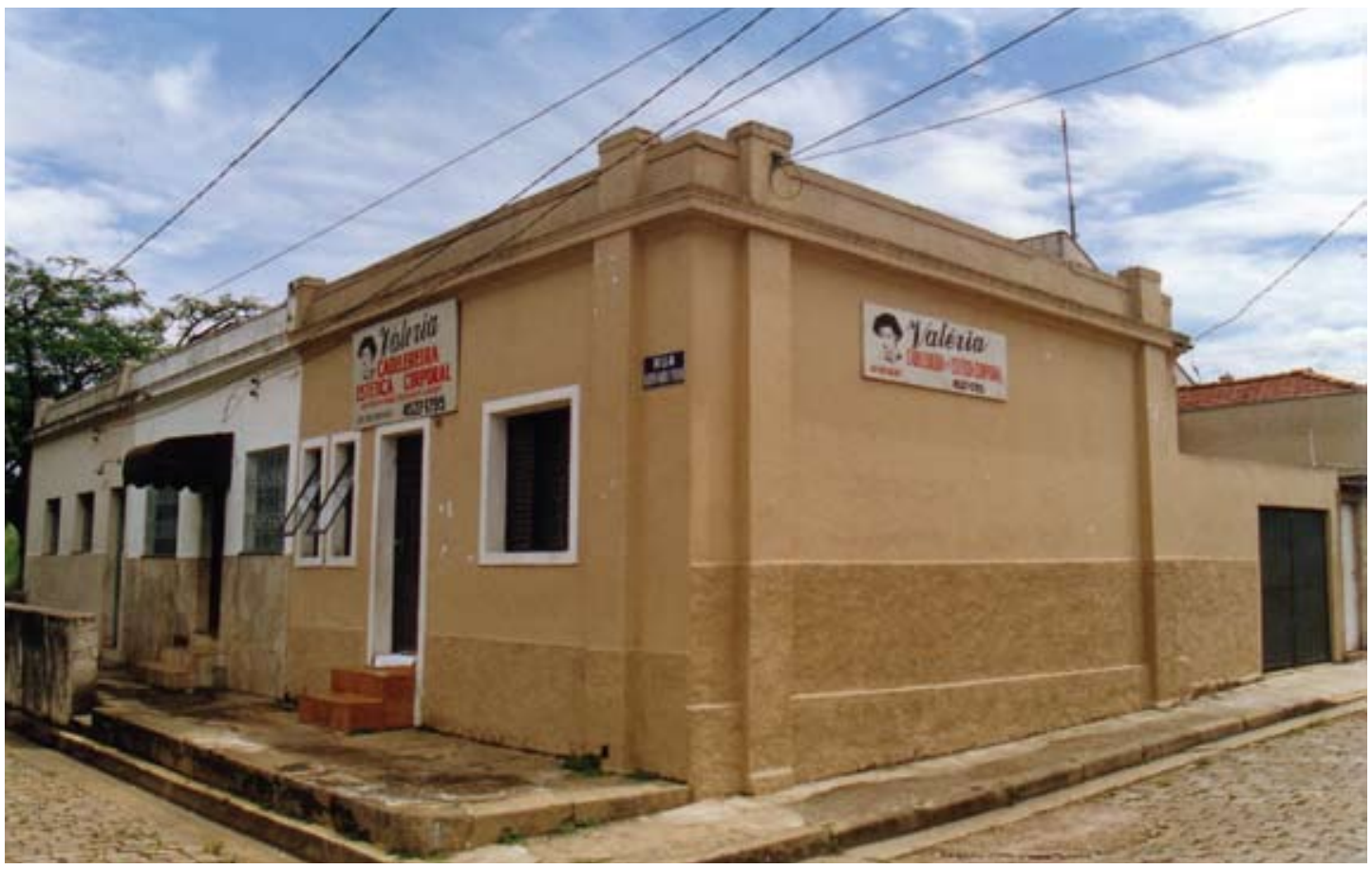

Figura 35 - Vila Operária da Argos Industrial (conhecida como Vila Argos Velha), em Jundiaí (SP). Fotografia de Philip Gunn, 2002.

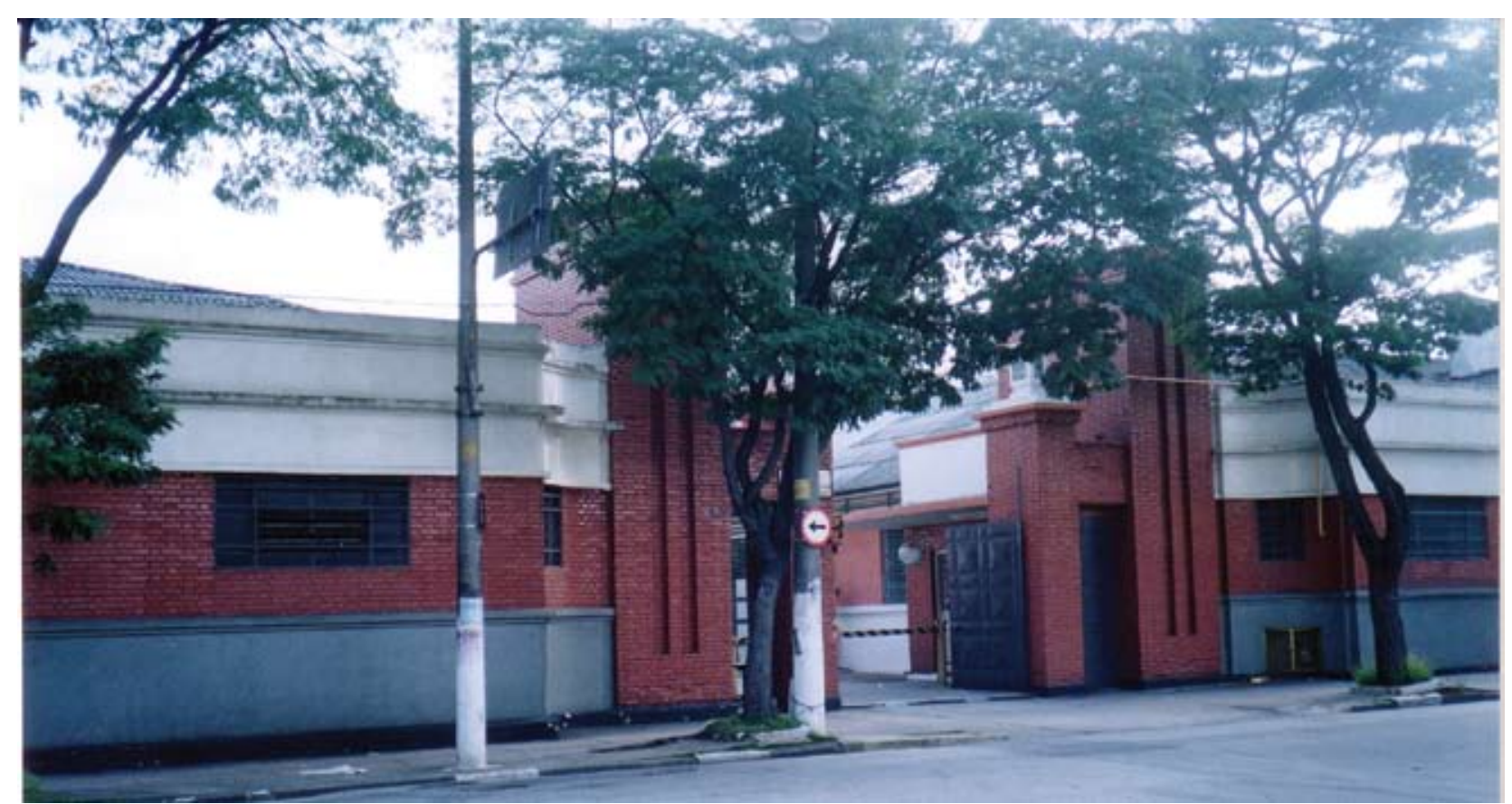

Figura 36 - Portaria da Fiação, Tecelagem e Estamparia Ypiranga Jafet, no bairro do Ipiranga, em São Paulo (SP). Fotografia de Telma de Barros Correia, 2005. 


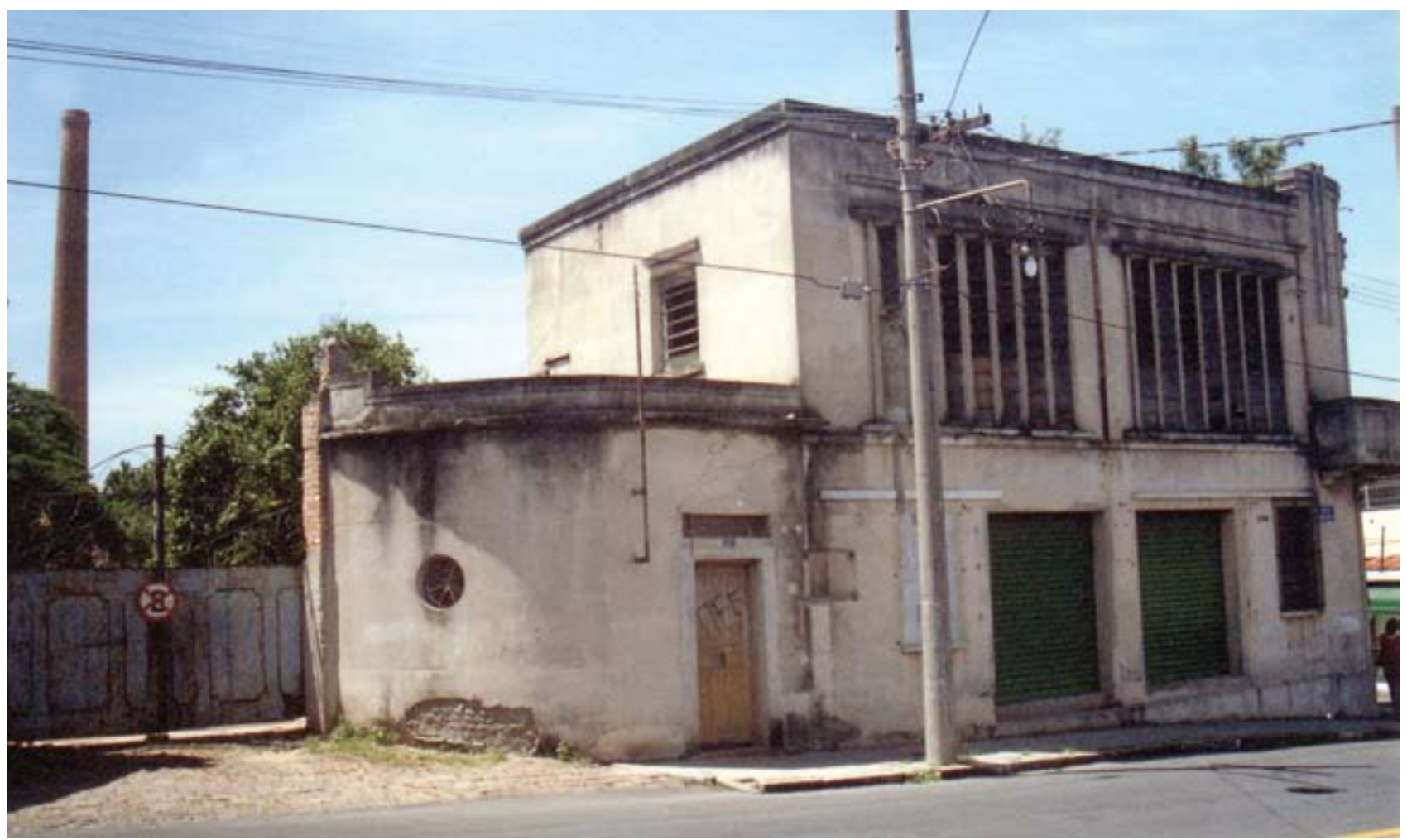

Figura 37 - Portaria da Companhia de Fiação e Tecidos Santa Maria, em Sorocaba (SP). Fotografia de Philip Gunn, 2001.

Um exemplo expressivo de arquitetura de tendência art déco de inspiração náutica é o prédio da Creche Condessa Marina Crespi, construído na Mooca pelo Cotonifício Rodolfo Crespi. Projetado pelo arquiteto italiano Giovanni Battista Bianchi, em 1936, o prédio incorpora referências a passadiços e escotilhas, além mastros e formas curvas que também remetem a navios (Figura 38).

Construído entre 1938 e 1945, o prédio central de escritórios da Companhia Taubaté Industrial é, talvez, a construção mais expressiva vinculada ao Art déco erguida por indústria no estado. É obra da Companhia Predial Taubaté, administrada, na época, pela principal acionista da fábrica, a família Guisard, da qual fazia parte seu diretor gerente Félix Guisard ${ }^{45}$. A composição volumétrica do edifício é escalonada, integrada por prismas ortogonais, um dos quais se eleva, incorporando grandes janelas, subdivididas em vãos menores que enfatizam sua altura. No alto, ostenta um grande relógio circular, que ganha expressividade por integrar-se às formas escalonadas. Os volumes são dotados de pilastras com arremates escalonados e utilizam o recurso da sobreposição de planos de fachadas. No bloco inferior, os cheios se sobrepõem aos vazios e a ênfase é colocada na entrada, com seu amplo portão sob marquise. Outros
45. Em torno de 1944, os engenheiros Urbano Pereira e Iório Ciciota participaram do projeto e construção da vila operária da Companhia Taubaté Industrial, realizado pela Companhia Predial Taubaté. Não foi possível, entretanto, obter informações sobre a autoria do projeto do prédio de escritórios da fábrica. Ver Maria Cristina Martinez Soto (1996); e Renato Penna et al. (1992). 


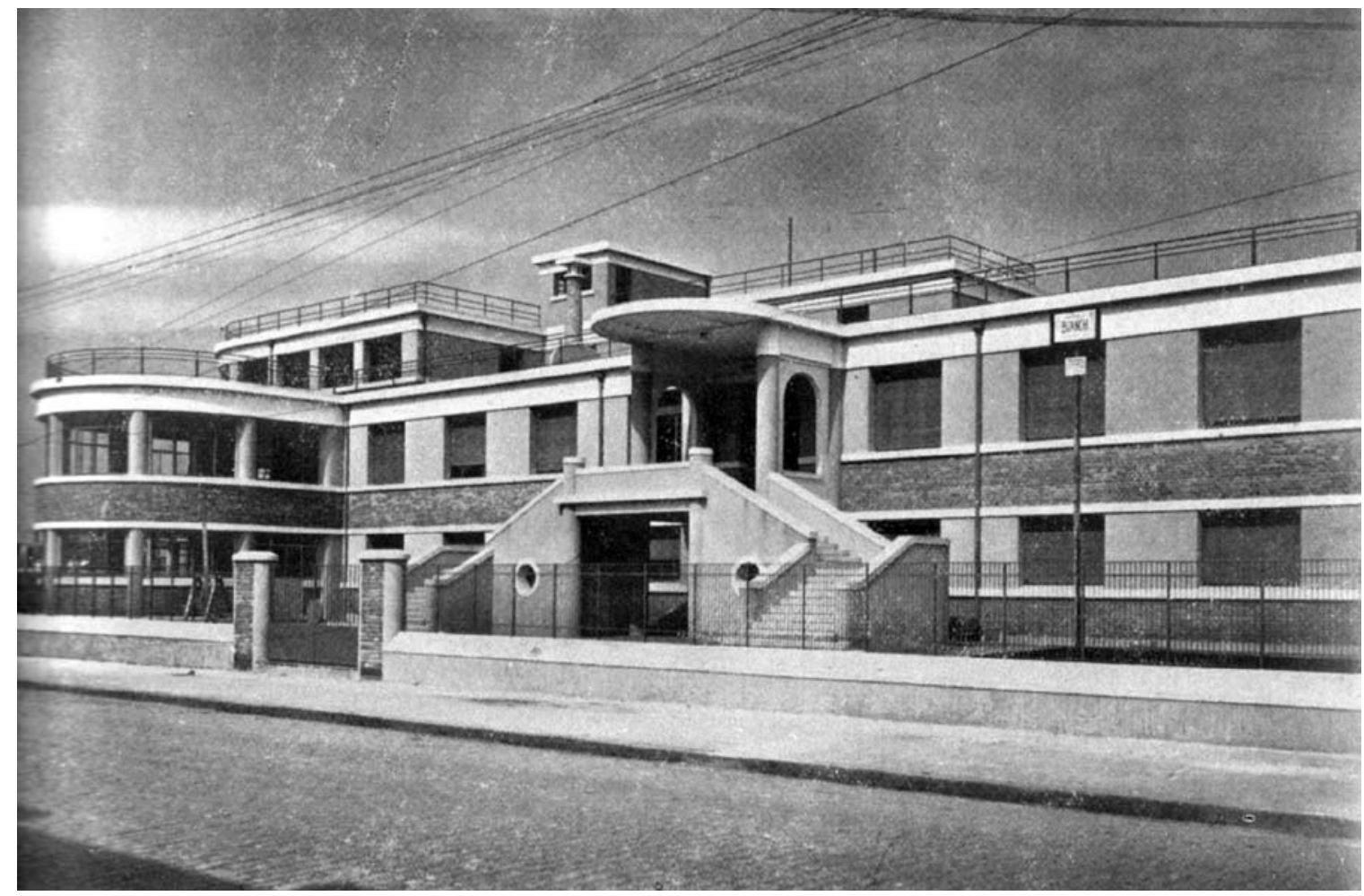

Figura 38 - Prédio da Creche Condessa Marina Crespi, construído na década de 1930 pelo Cotonifício Rodolfo Crespi, no bairro da Mooca, São Paulo (SP). BARDI, 1981, p. 63.

prédios desta fábrica, dispostos em torno desta edificação central, adotam características semelhantes entre si. Neles, reaparecem as pilastras com arremates escalonados. Nestes casos, contrastando com o tijolo aparente das paredes, as pilastras recebem um revestimento em argamassa de pó de pedra e mica, muito utilizada no Brasil nas décadas de 1930 e 1940, sob o nome de cirex ou "granito" (Fuguras 39 e 40).

Outro prédio industrial de arquitetura com tendência art déco é o da Fábrica de Meias Luppo, em Araraquara. Sua composição volumétrica consiste em jogo de prismas ortogonais, dois dos quais compõem uma torre central que domina o conjunto. A torre tem elementos escalonados e é dotada de uma sobreposição de planos de fachadas e de rasgos com vãos estreitos, que acentuam sua verticalidade. Um relógio disposto no alto converte-se em elemento de destaque da composição. $\bigcirc$ tratamento da esquina, com quina arredondada, e os desenhos geométricos em metal das esquadrias e dos elementos de proteção dos aparelhos de ar condicionado são outros aspectos expressivos na construção (Figura 41 ).

A descrição dos exemplares ao longo deste item indica claramente a recorrência ao uso de algumas soluções, tais como a composição volumétrica 


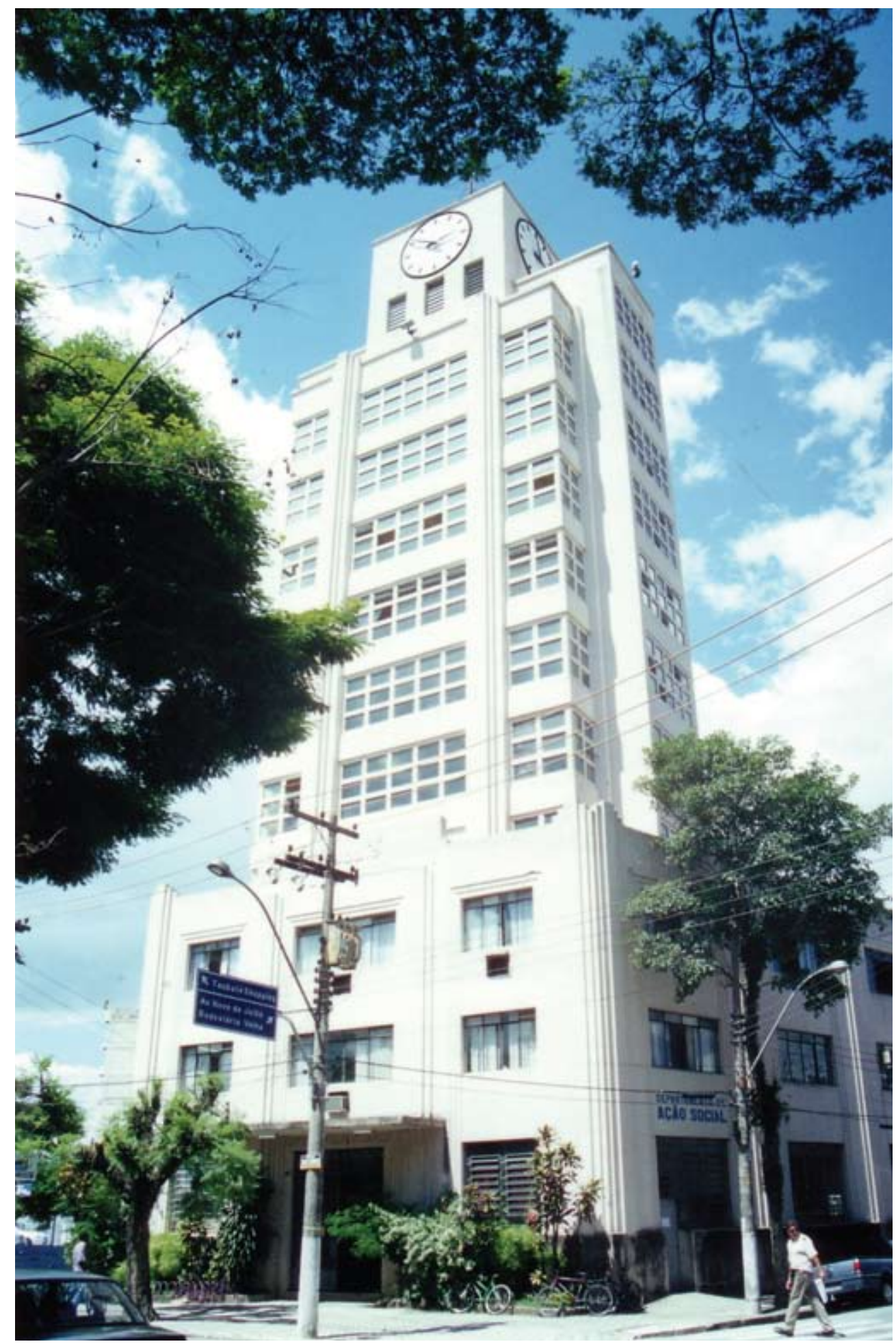

Figura 39 - Prédio de escritórios da Companhia Taubaté Industrial, inaugurado em 1945, em Taubaté (SP). Fotografia de Philip Gunn, 2001 


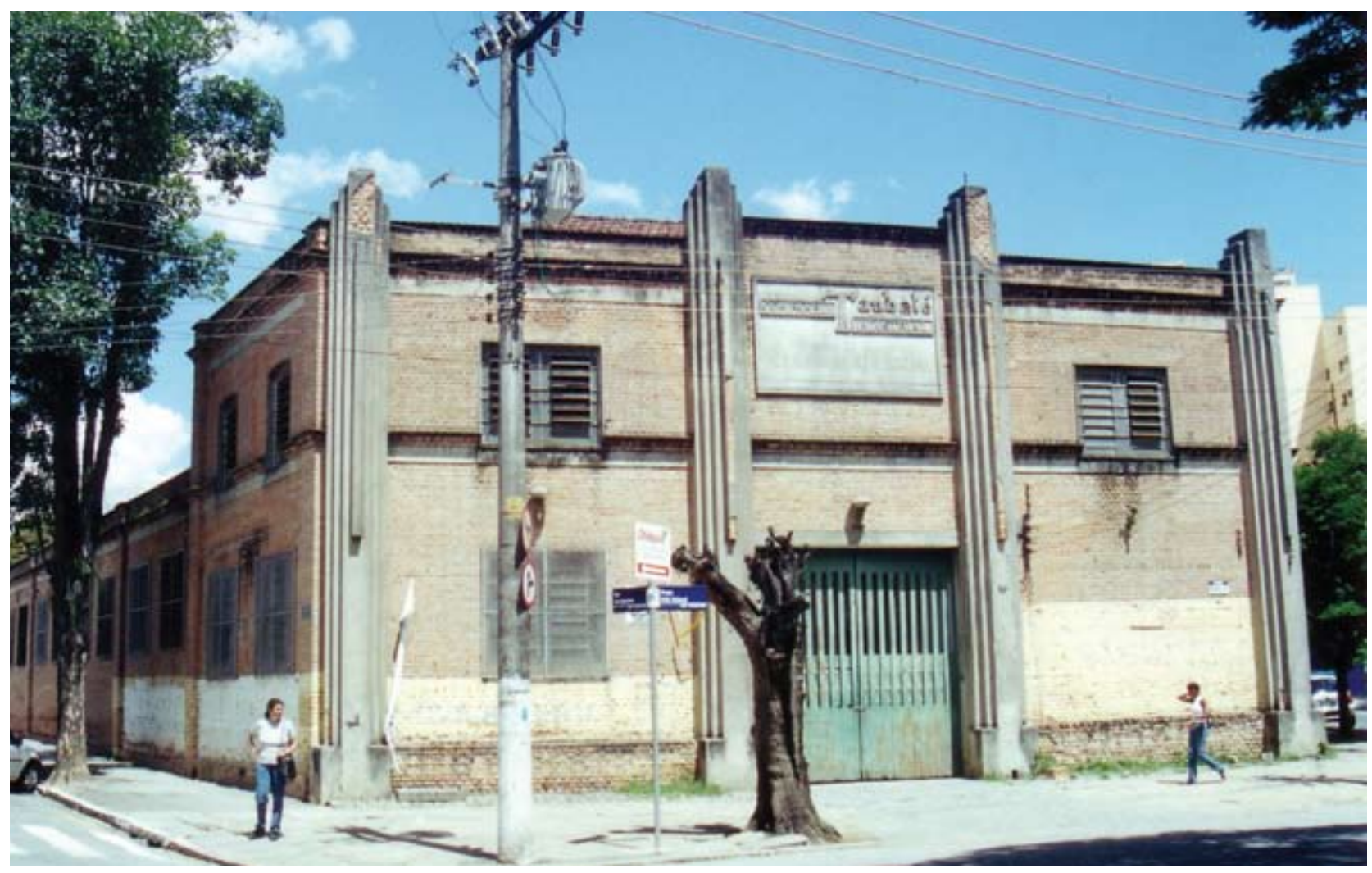

Figura 40 - Prédios da Companhia Taubaté Industrial, em Taubaté (SP). Fotografia de Philip Gunn, 2001.

escalonada, dominada por torre central, em fachadas de fábricas e de igrejas; e as platibandas e/ou pilastras escalonadas, dispostas de modo a demarcar cada moradia integrante de um conjunto de casas operárias. No caso do conjunto em Goiana, tratado a seguir, tais características persistem nas casas operárias; entretanto, na casa do industrial, o estilo assume características ímpares, contrastando com o limitado vocabulário arquitetônico observado no Art déco fabril brasileiro.

Companhia Industrial Fiação e Tecidos Goyanna: fábrica e vila operária

As construções que compõem a fábrica e a vila operária criada pela Companhia Industrial Fiação e Tecidos Goyanna, situadas em Goiana, Pernambuco, compuseram o que foi, provavelmente, um dos mais notáveis conjuntos de gosto déco erguido por fábrica no Brasil. Construído durante a segunda metade dos anos 1930 e a década de 1940, este conjunto chama a atenção por sua unidade estilística e por algumas raras soluções arquitetônicas. 


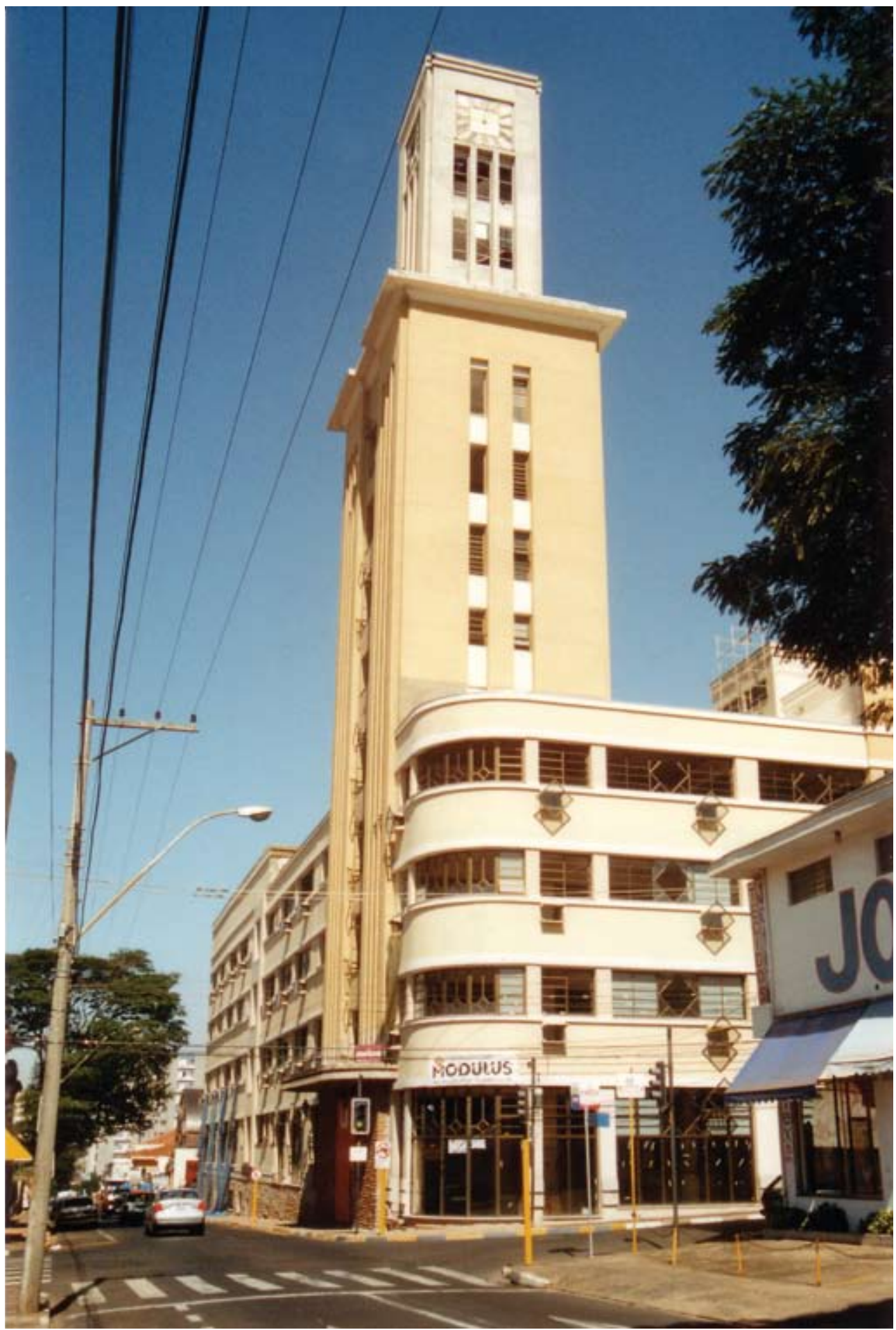

Figura 41 - Fábrica de Meias Luppo, em Araraquara (SP). Fotografia de Philip Gunn, 2002. 
46. Em março de 1936, o jornal $O$ Goianense anunciava a intenção de José Albino de construir uma vila operária junto à fábrica de tecidos (O Goianense, 2103-1936, p.4). Em outubro do mesmo ano, o jornal referia-se às grandes obras que estavam sendo realizadas pela fábrica, e em abril do ano seguinte anunciava a inauguração de casas de propriedade da empresa $(O$ Goianense, 25-10-1936, p.4; e 18-04-1937, p 4). Em matéria publicada 1939, a revista Cidade Mauricéa retrata a empresa em meio a este esforço de modificação. Contando na ocasião com 88 casas construídas e outras em projeto, a vila operária da fábrica foi um dos aspectos sublinhados pela revista. Outros aspectos assinalados foram iniciativas de criar gabinete médico e dentário, escola, seções semanais gratuitas de cinema e refeições diárias gratuitas para operários e seus familiares (Cidade Mauricéa, 1939).

47. Antes de adquirir a fábrica de Goiana e estabelecerse na cidade, José Albino Pimentel foi sucessivamente proprietário de lojas de tecidos em várias cidades do estado de Pernambuco. Em uma delas - Belo Jardim na década de 1910, construiu uma casa para residir: construção ampla, onde o gosto clássico se expressa na fachada (exceto pela forma em ogiva dos vãos e pela assimetria da localização da porta) e na simetria da disposição em planta (rompida apenas na parte que concentra os serviços).
Fundada em 1893 e iniciando sua produção em 1895, a Companhia Industrial Fiação e Tecidos Goyanna integrou o pólo industrial têxtil que se constituiu em torno do Recife a partir do final do século XIX. A fábrica viveu seu momento de maior vigor durante um período que se inicia na segunda metade dos anos 1930 e se estende pela década seguinte. O momento coincide com a gerência de José Albino Pimentel, iniciada em 1935, que introduziu na empresa amplas mudanças, incluindo renovação de maquinário e reforma das instalações. Sob o último aspecto, antigos galpões foram ampliados e modificados, e foi erguido um conjunto de novas edificações ${ }^{46}$.

Reunindo instalações fabris, uma extensa vila operária (472 moradias), casas para funcionários especializados, equipamentos comunitários e a casa do proprietário, o conjunto erguido pela fábrica apresenta amplas dimensões e forte unidade formal. Seguindo uma tendência comum em fábricas e vilas operárias criadas no Brasil na época, o conjunto de Goiana adota um vocabulário art déco, estabelecendo fortes contrastes com as igrejas, mosteiros e casas antigas em cuja vizinhança se instalou.

Não há, nos arquivos da família Pimentel, plantas originais dessas construções e, segundo informação prestada pelo filho de José Albino Pimentel, que o sucedeu na gerência da fábrica, estas plantas nunca existiram, pois teria sido o próprio industrial que, de maneira empírica, teria comandado as obras, mesmo não tendo formação profissional ligada a construção ${ }^{47}$. Falecido em 1954, ele não deixou escritos que possam fornecer pistas sobre as referências de suas originais realizações no campo da arquitetura. Para ampliar o conjunto fabril de Goiana - cidade dotada de um conjunto notável de arquitetura colonial - demoliu algumas casas antigas, das quais aproveitou os azulejos portugueses das fachadas para revestir as paredes dos salões da residência que ergueu para morar no local.

No conjunto fabril de Goiana, a linguagem art déco surge simplificada, solidarizando-se com o utilitarismo fabril e com a busca de um efeito de unidade no conjunto. Seus temas se expressam em formas geometrizantes, no uso de colunas cilíndricas, de detalhes decorativos geométricos nas fachadas (frisos e marquises), de formas escalonadas (frontões e detalhes nas platibandas), de paredes com superfícies curvas e de vãos (portas, janelas, rasgos e vitrais) com desenhos quadrangulares ou circulares (Figura 42).

Ao longo de uma rua, prolongam-se as fachadas regulares das moradias dos operários, repetindo uma mesma composição de fachadas. $\bigcirc$ ritmo das fachadas mantém-se com poucas alterações, mesmo em construções de escala superior, como as instalações fabris, a casa do proprietário e os equipamentos de uso coletivo, estes também dispostos ao longo da mesma via, como ocorre inclusive com as casas destinadas aos técnicos especializados, 


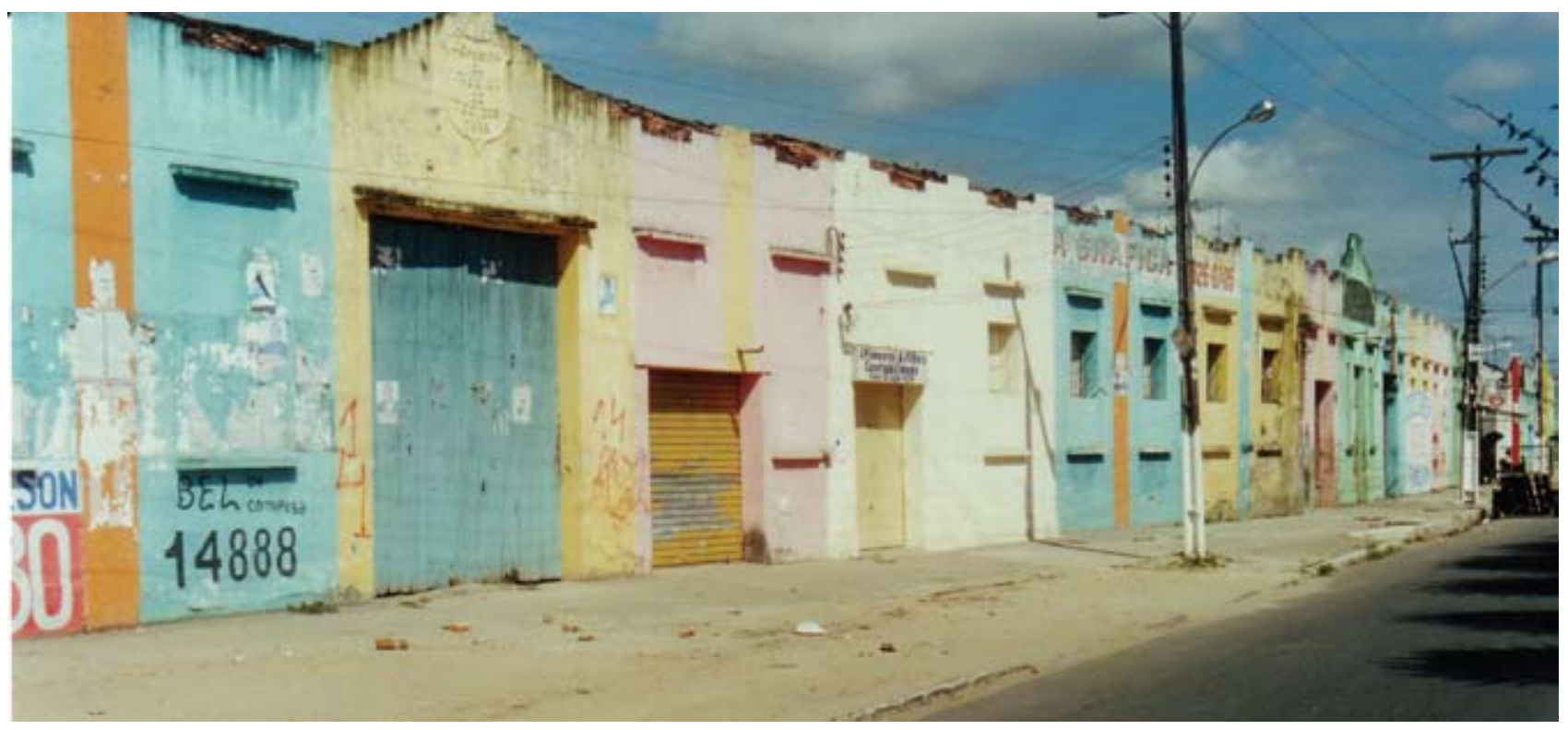

Figura 42 - Prédios da Companhia Industrial Fiação e Tecidos Goyanna, em Goiana (PE). Fotografia de Philip Gunn, 2000.

integrando-se formalmente no conjunto. A vila espalha-se por ruas contíguas, mantendo sempre suas características arquitetônicas básicas.

As moradias para operários estavam dispostas em longos blocos de casas geminadas. Seguiam dois modelos. $\bigcirc$ menor era dotado de uma janela e uma porta na fachada. Tinha 57,2 metros quadrados de área construída e 28 metros quadrados de área não construída, constando de sala, três quartos, corredor, cozinha e quintal com sanitário externo. Para os operários mais qualificados e para os chefes de seção, destinavam-se casas um pouco maiores, cujas fachadas contavam com porta e duas janelas e com programa que incluía três salas, cozinha, quatro quartos e quintal com sanitário externo. Tinham 102.7 metros quadrados de área construída e 50 metros quadrados de área não construída. Em ambos os casos, a implantação seguia o padrão urbano colonial: lotes estreitos e compridos e ausência de recuos na frente e nas laterais das construções.

Tais casas, embora tivessem dimensões reduzidas, conferiram ao conjunto um efeito monumental, pela repetição ritmada de portas e janelas intercaladas por faixas verticais em alto relevo. Estas faixas, avançando na platibanda em arremates escalonados, pontuavam a imensa fachada regular constituída pelo conjunto das casas. Algumas casas eram dotadas de elemento vazado, disposto acima das portas e janelas, denotando preocupação com a ventilação permanente dos espaços internos.

Na vila, as casas destinadas aos técnicos especializados concentravamse na extremidade mais próxima ao centro da cidade. Havia um bloco de três 
casas, com entrada pela lateral do terreno ou através de um pequeno terraço. Contavam com duas salas, dois quartos, corredor, cozinha e quintal com sanitário externo. Tinham 90 metros quadrados de área construída e 87 metros quadrados de área não construída. Sua implantação também seguia os modelos urbanos tradicionais: estavam construídas em lotes estreitos e compridos, não tinham recuos frontais (com exceção de uma) nem laterais. A composição de suas fachadas, dotadas de elementos ornamentais geométricos, também remetia ao vocabulário art déco (Figuras 43 a 45).
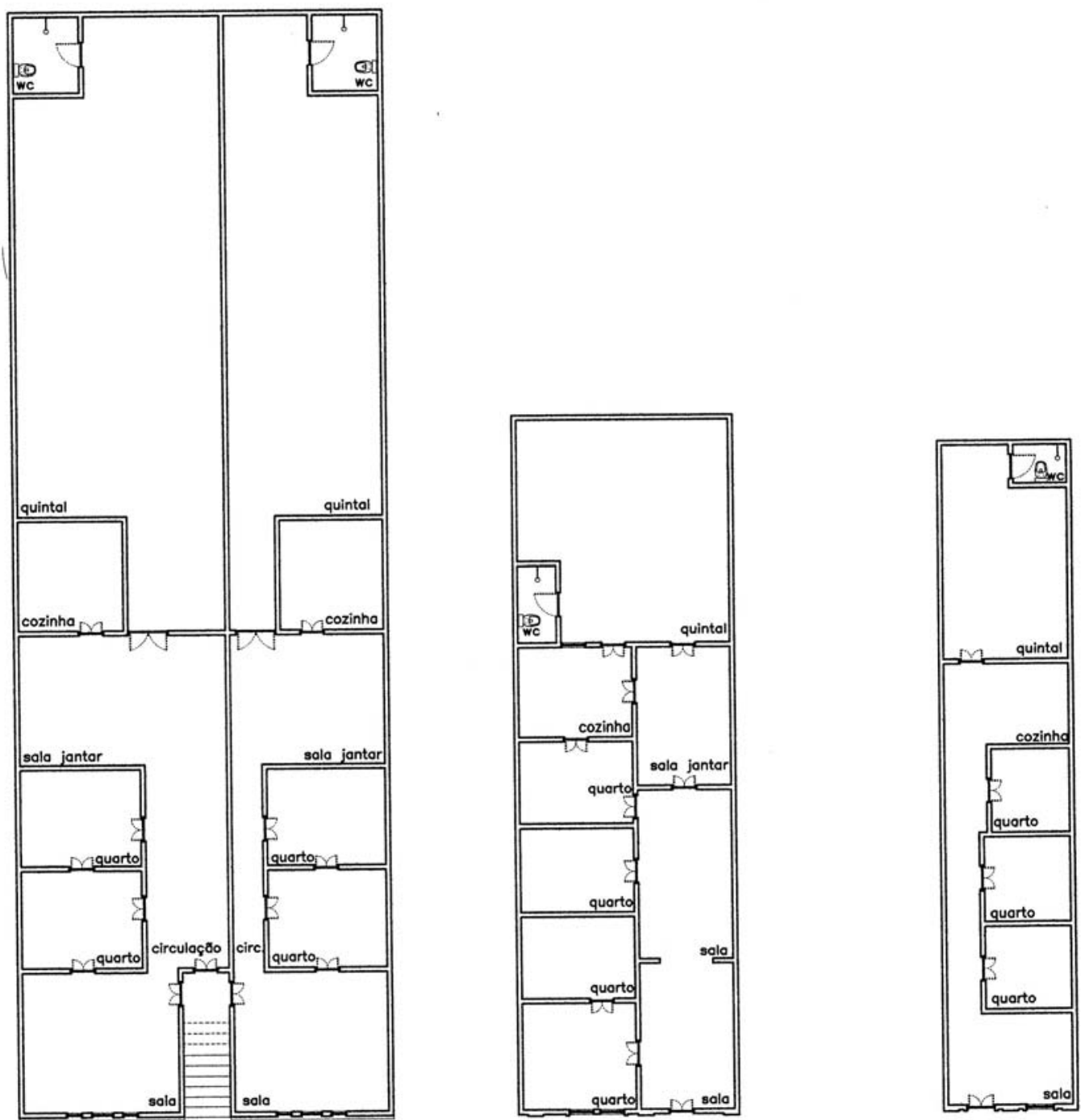

Figura 43 - Plantas de casas para operários e técnicos da Companhia Industrial Fiação e Tecidos Goyanna, em Goiana (PE). Acervo de Telma de Barros Correia, 2003. 


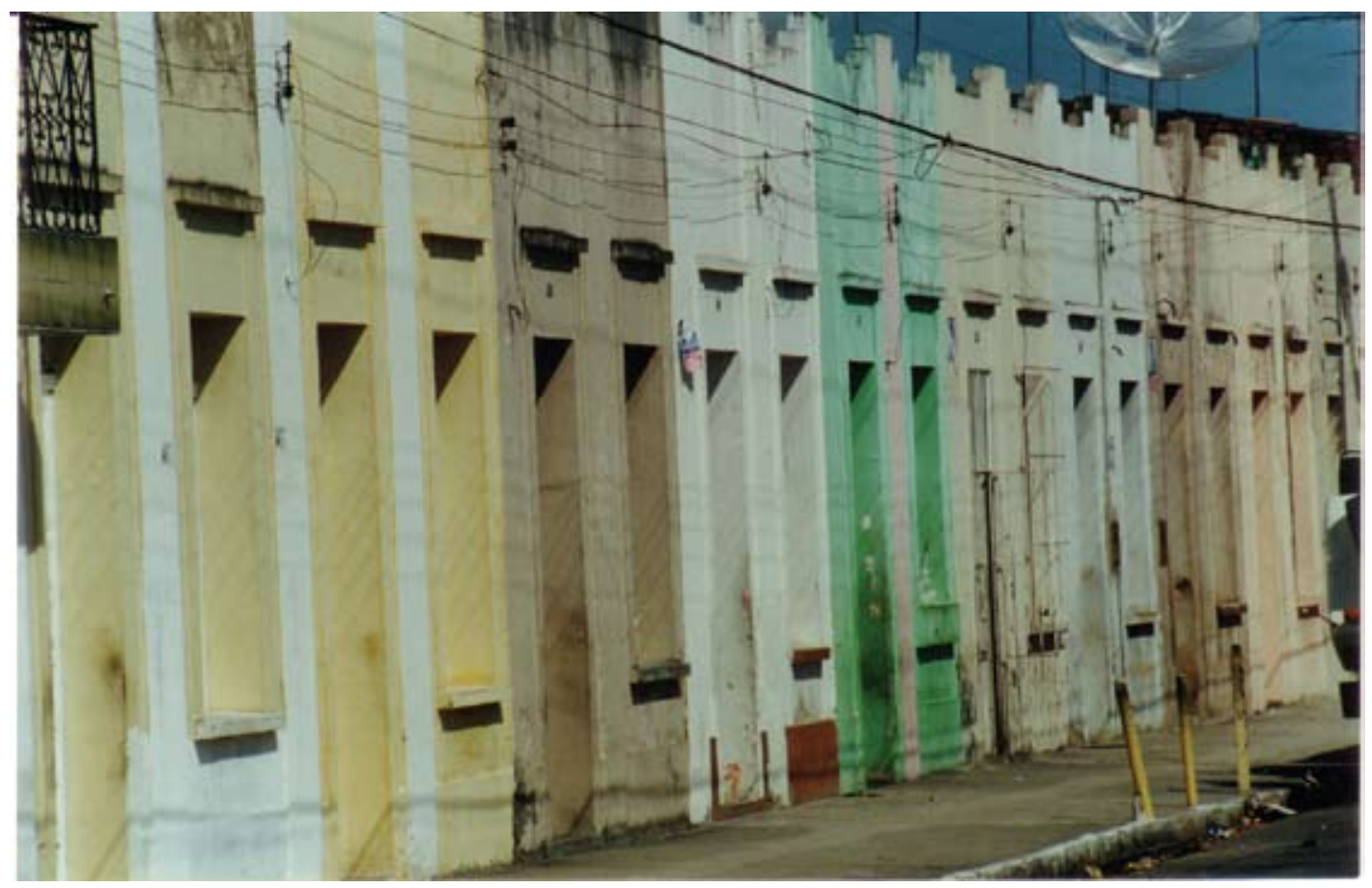

Figura 44 - Casas para operários da Companhia Industrial Fiação e Tecidos Goyanna, em Goiana (PE). Fotografia de Philip Gunn, 2000.

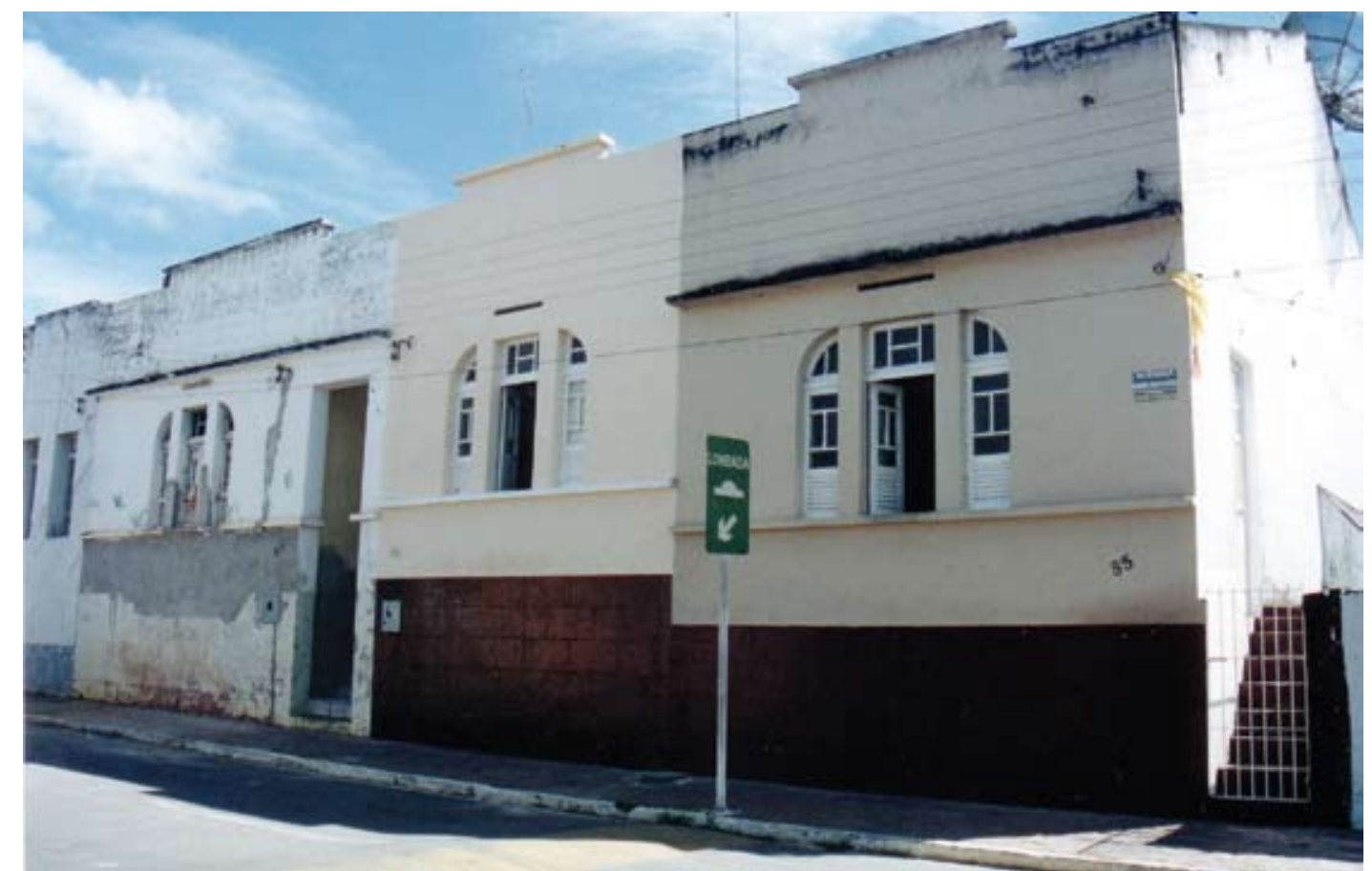

Figura 45 - Casas para técnicos da Companhia Industrial Fiação e Tecidos Goyanna, em Goiana (PE). Fotografia de Philip Gunn, 2000. 
Havia ainda um grupo de doze casas - destinadas a gerentes e conhecidas como "bangalôs" - que eram geminadas duas a duas, dispondo de terraço e recuo com jardim lateral. Eram casas amplas, cujos interiores reuniam duas salas, cozinha, quatro quartos, sanitário, dois terraços, lavanderia, garagem e dependências para empregados. Tinham 170 metros quadrados de área construída e 170 metros quadrados de área ocupada por jardim e quintal. As fachadas das casas geminadas eram tratadas como uma construção única, simétrica, ampliando o efeito plástico resultante, acentuado pela sucessão de construções semelhantes ao longo do quarteirão. Também nestas casas foram introduzidos elementos destinados a compatibilizar a construção com o clima quente, como é o caso do amplo terraço em $L$ e do rasgo na alvenaria sobre a janela, dotada de venezianas, da fachada (Figuras 46 e 47).

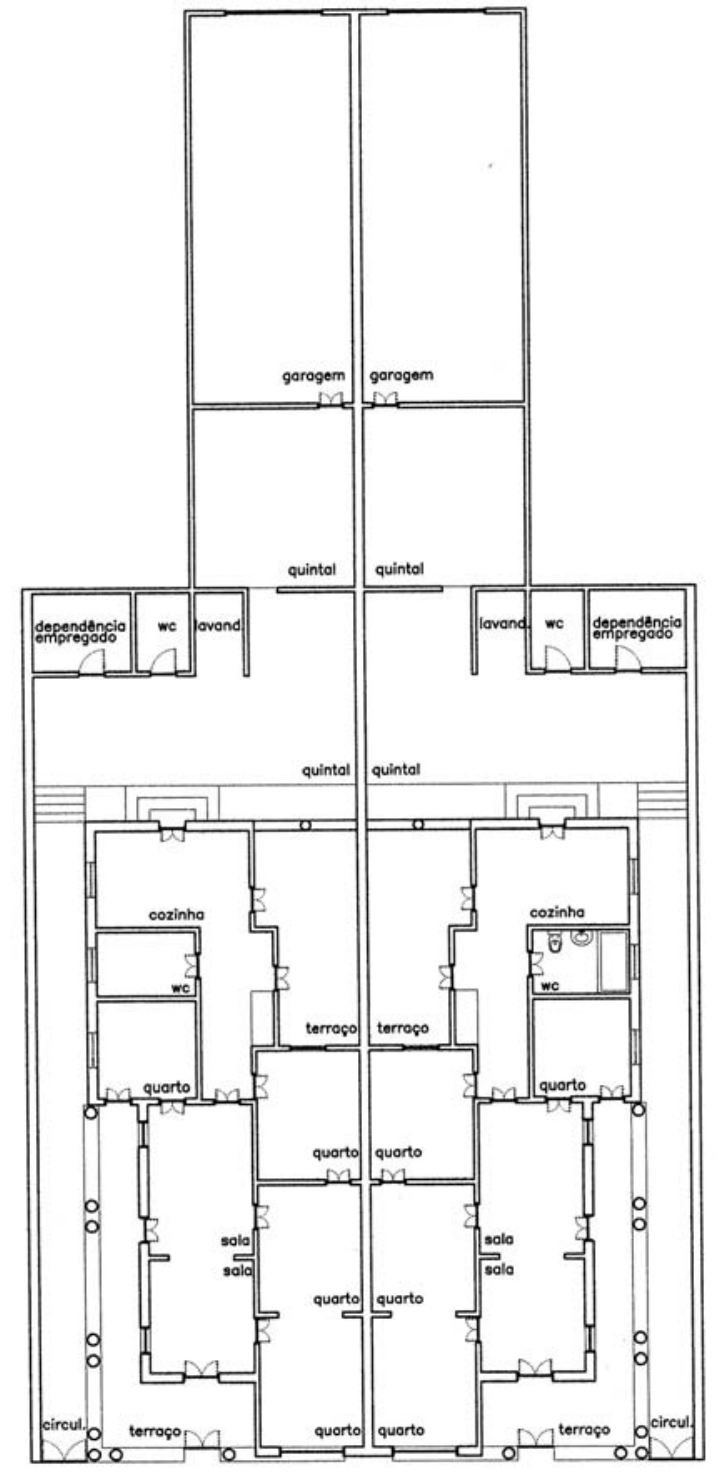

Figura 46 - Planta de casas para gerentes da Companhia Industrial Fiação e Tecidos Goyanna, em Goiana (PE). Acervo de Telma de Barros Correia, 2003. 


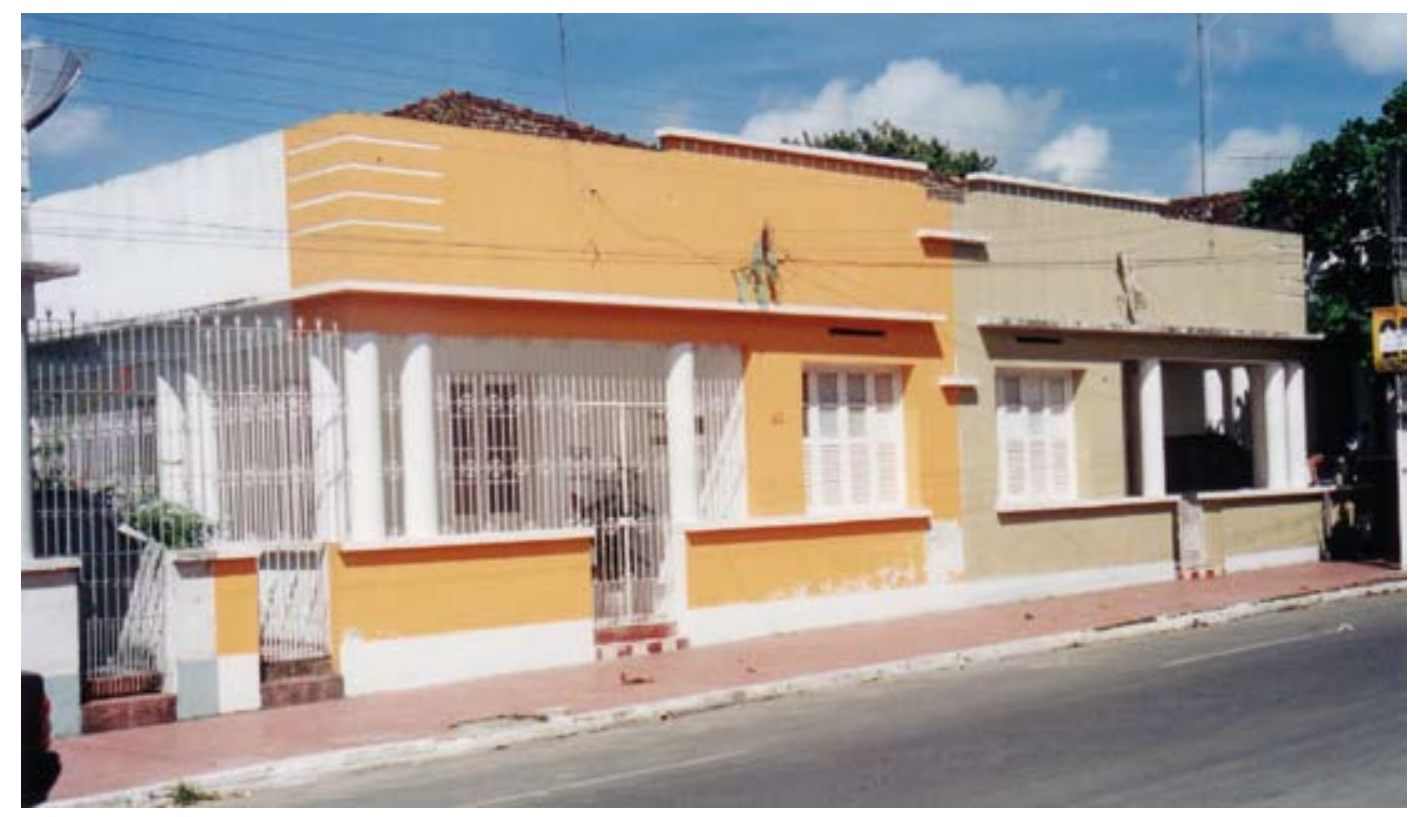

Figura 47 - Casas para gerentes da Companhia Industrial Fiação e Tecidos Goyanna, em Goiana (PE). Fotografia de Philip Gunn, 2000.

A hierarquia existente no interior da fábrica se refletia no tipo e na forma das moradias. As casas destinadas aos operários eram menores e, como único recurso decorativo de fachada, contavam com as pilastras verticais dispostas entre os vãos. Nas casas dos gerentes, os elementos decorativos de fachada se multiplicam em frisos, detalhes em baixo relevo, marquise e nas colunas cilíndricas dos terraços.

Junto a estas casas foi construído, provavelmente na mesma época, um prédio destinado à sorveteria. Sua composição de fachada recupera elementos presentes nestas últimas moradias: colunas cilíndricas, detalhes em baixo relevo e marquise. Aqui, a disposição das colunas - duas a duas - remete à casa do industrial, mas os ornatos são reduzidos a linhas tênues, em baixo relevo. Implantado no centro de um pequeno quarteirão, o prédio diferencia-se dos demais, por ter as quatro quinas arredondadas, recuperando um recurso comumente usado em edifícios de tendências art déco (Figura 48). No mesmo quarteirão foi construído um pequeno quiosque, empregando formas escalonadas.

As colunas em formato cilíndrico são uma marca de prestígio que assinala algumas construções do conjunto, surgindo apenas em prédios diferenciados, como os "bangalôs" e a sorveteria. As faixas verticais em alto relevo, entre os vãos, por sua vez, surgem apenas nos prédios fabris e nas casas dos operários. Sob este aspecto, a moradia do patrão estabelece uma síntese: é a única construção da vila que reúne os dois elementos, colunas cilíndricas e faixas em alto relevo verticais. Parte de sua fachada repete a estrutura básica das moradias mais simples, sugerindo uma reunião de várias pequenas casas. Em

Annals of Museu Paulista. v. 16. n.2. July - Dec. 2008. 


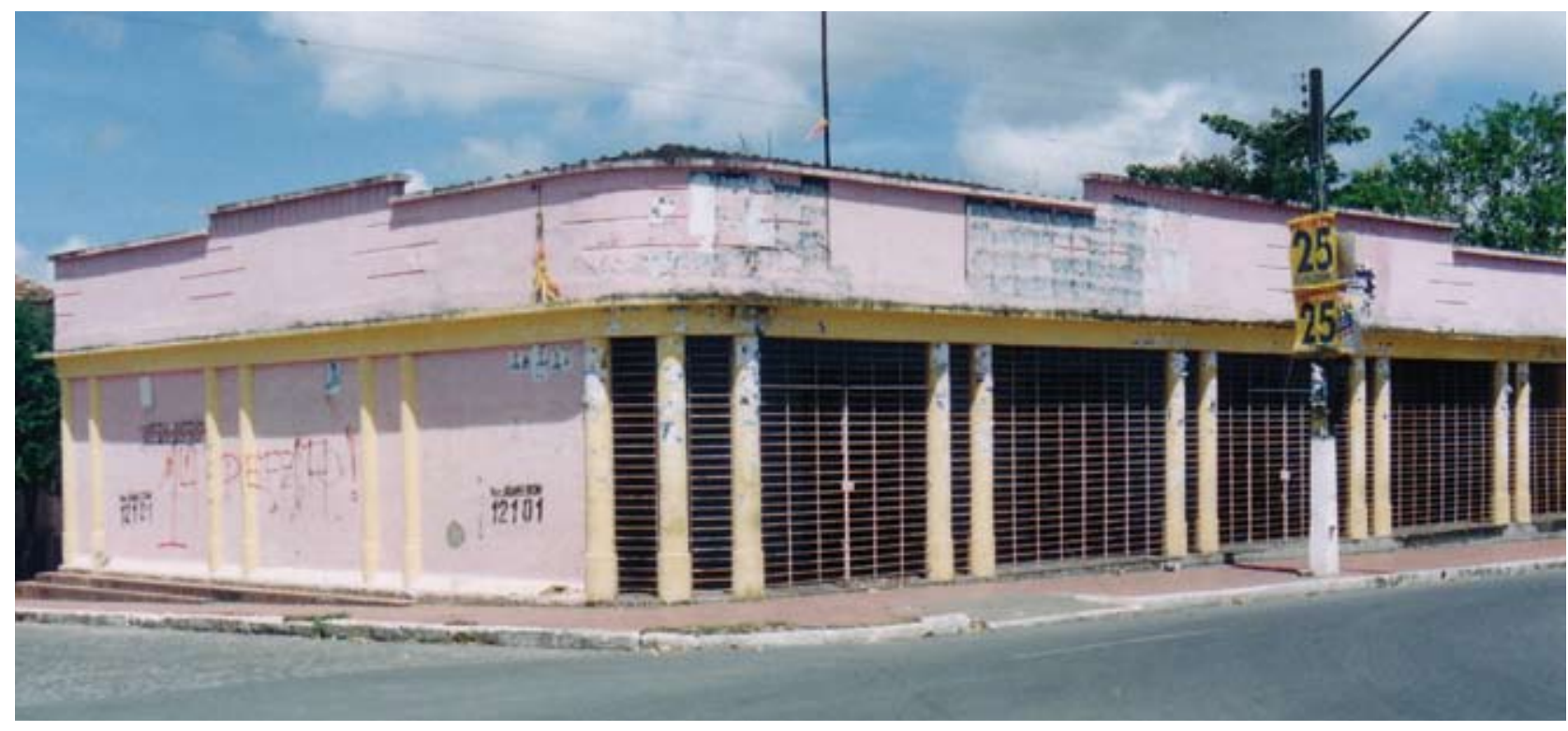

Figura 48 - Prédio da sorveteria da Companhia Industrial Fiação e Tecidos Goyanna, em Goiana (PE). Fotografia de Philip Gunn, 2000.

outro segmento da fachada, entretanto, as faixas verticais distanciam-se e surgem acima de colunas dispostas duas a duas, enquanto portas e janelas cedem lugar a vãos que se abrem para uma extensa galeria. A síntese formal estabelecida nesta casa pode ser objeto de várias especulações. Entre outras coisas, pode indicar o uso peculiar deste prédio, ao mesmo tempo moradia privada e sede social da vila operária.

Companhia Industrial Fiação e Tecidos Goyanna: a casa do industrial

No conjunto fabril de Goiana, a residência do industrial é, sem dúvida, o aspecto mais surpreendente e inusitado do lugar. Sua forma e seu programa incorporam características inovadoras. Trata-se de uma edificação que subverte as relações entre público e privado, entre exterior e interior, além de avançar para uma arquitetura solidária com o clima tropical.

A edificação tem cerca de quatro mil metros quadrados de área não construída e 1650 metros quadrados de área construída. Situa-se em frente aos escritórios da fábrica e reúne, em um único espaço, a moradia do industrial, um amplo cinema, um salão de jogos e um parque dotado de jardins e de uma plataforma com arquibancadas para festas e jogos. Uma superfície - ora fechada, ora vazada - circunscreve os contornos do lote, configurando um retângulo dentro do qual se distribuem casa, cinema e jardins. A fluidez dos espaços internos contrasta fortemente com a regularidade do aspecto externo da 
construção, com sua parede de altura constante, pontuada por faixas verticais em alto relevo e vãos regularmente dispostos. A regularidade dessa parede não é interrompida nem mesmo quando delimita o jardim interno na divisa lateral do lote; mas, neste ponto, os vãos verdadeiros são substituídos por falsos.

Nela o repertório formal art déco é amplamente mobilizado. Há vasto emprego de colunas cilíndricas (na galeria frontal, nos salões internos, no cinema, na sala de jogos e na suíte do industrial); uso de marquise e de vãos em forma de escotilha (na suíte do industrial); e a fachada está ornamentada com faixas verticais em alto relevo que, na platibanda, avançam em arremates escalonados (Figuras 49 e 50).

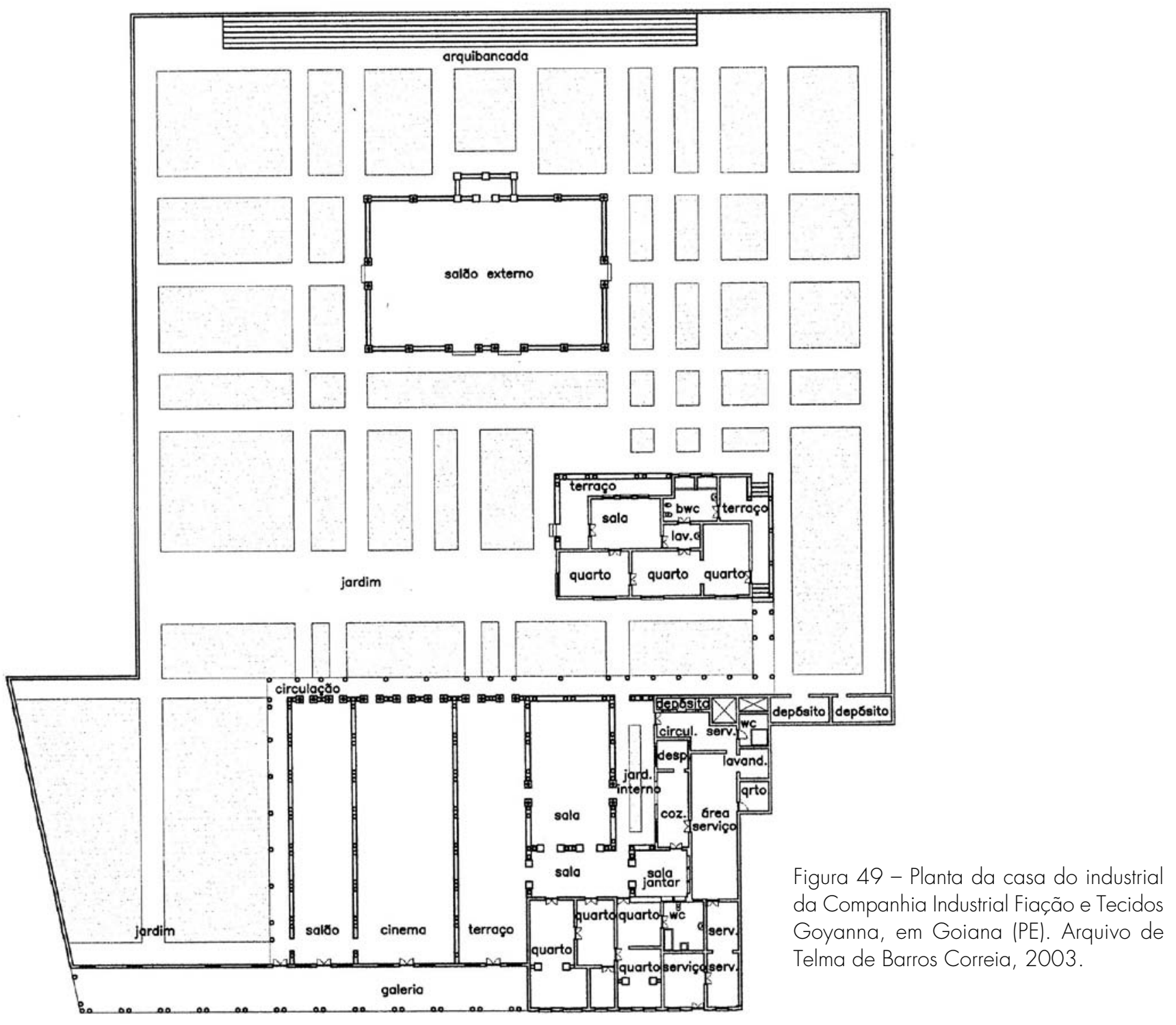




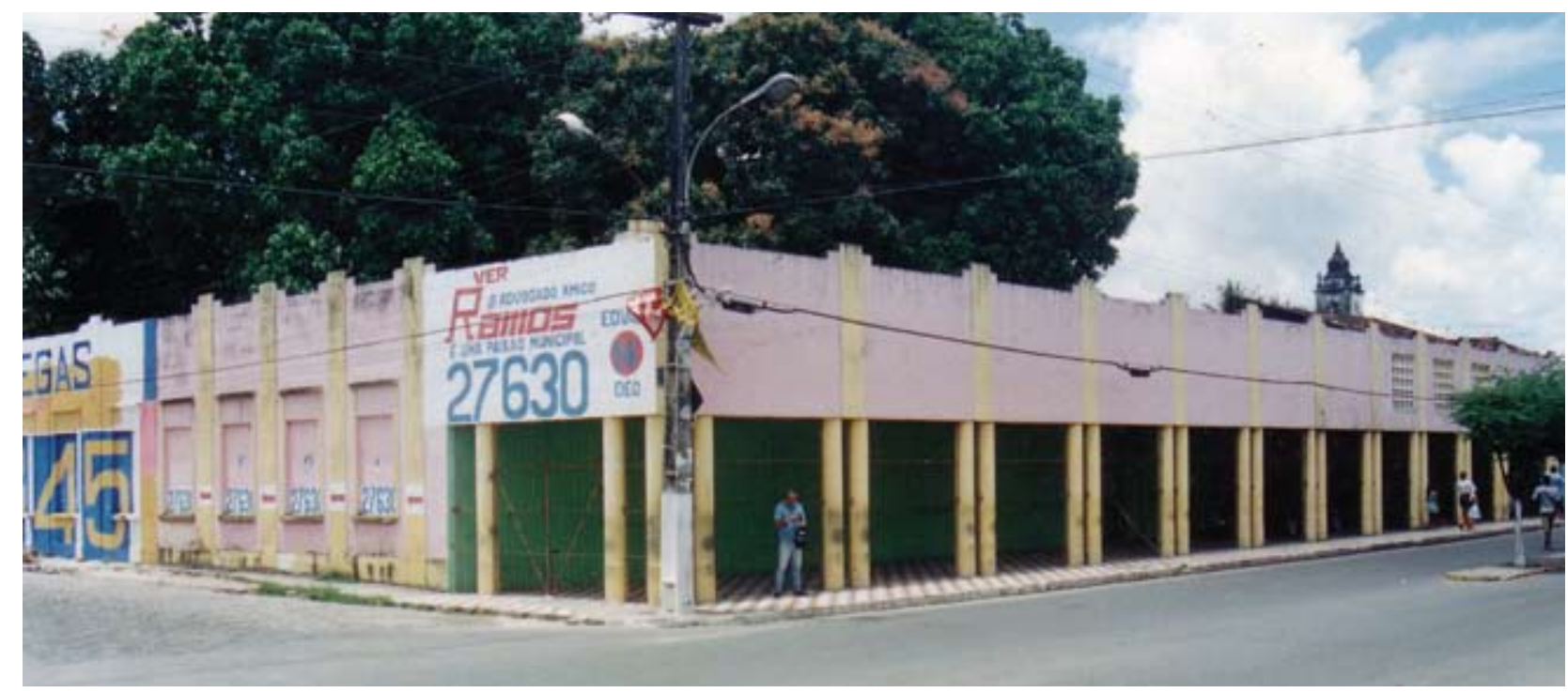

Figura 50 - Casa do industrial da Companhia Industrial Fiação e Tecidos Goyanna, em Goiana (PE). Fotografia de Philip Gunn, 2000.

Novas fronteiras: entre público e privado, entre interior e exterior

programa da construção reúne uma moradia privada e espaços de uso coletivo, contrapondo-se às usuais barreiras que se estabelecem entre essas duas esferas. $\bigcirc$ prédio é, antes de tudo, uma moradia privada, contida no interior das altas paredes que a cercam. Em determinados momentos, entretanto, abria-se para a comunidade, que utilizava o cinema e, menos freqüentemente, participava de grandes festas realizadas na plataforma disposta em meio aos jardins existentes nos fundos do lote. Essa ambigüidade entre o espaço de uso privado e o de uso coletivo se rebate numa certa transparência entre interior e exterior. A permeabilidade entre eles é assinalada tanto pelo uso do prédio quanto pela existência de uma galeria (percorrendo parte da fachada) e de painéis dotados de elementos vazados dispostos em algumas das paredes que separam galeria e o interior da casa.

A galeria remete às loggias, enquanto os jardins da casa - não pela forma, mas pela posição e uso - não deixam de lembrar os pátios, ambos elementos da arquitetura clássica, importantes em moradias luxuosas erguidas na cidade e no campo, especialmente durante o Renascimento. No Brasil, eles surgem no período colonial, nas moradias de índios e padres, nas missões criadas por jesuítas e em conventos; e, no século XIX, em núcleos fabris e em engenhos de açúcar. No século XX, as loggias reaparecem em moradias para operários de núcleos fabris do Nordeste.

Na casa do industrial, em Goiana, o pátio e as loggias surgem novamente e, somados aos grandes salões, diferenciam a casa do patrão das demais. Tal procedimento recupera uma antiga atribuição da loggia, associada 
à moradia de homens ricos e poderosos. No século XVI, Palladio defendia a necessidade de tornar a casa "conveniente à qualidade de quem terá que habitála" e argumentava que

para grandes homens e, especialmente, em uma República são requeridas casas com loggias e salas espaçosas e ornamentadas, para que em tais lugares se possam entreter com prazer aqueles que esperarem o patrão para saudá-lo ou pedir-the algum favor ${ }^{48}$.

Coerente com uma tendência vinculada ao Art déco, de reelaborar elementos da arquitetura do passado, nesta casa as loggias da fachada frontal e da suíte são dotadas de colunas, que também surgem nos salões, ao mesmo tempo em que, na composição de suas fachadas, incorporam-se platibanda, pilastras e óculos (Figuras 51 e 52).

Ao contrário do que se pode supor, o projeto da casa atenta para a busca de privacidade dos moradores, garantida pela setorização e por um agenciamento singular dos espaços internos. Sua ordem interna delimita claramente as diferentes áreas e a modalidade de acesso a elas. Assim, a galeria frontal é um espaço aberto, cujo piso se prolonga pela calçada. Revela-se como elemento
48. Cf. Andrea Palladio (1965, p. 37); tradução livre, da autora.

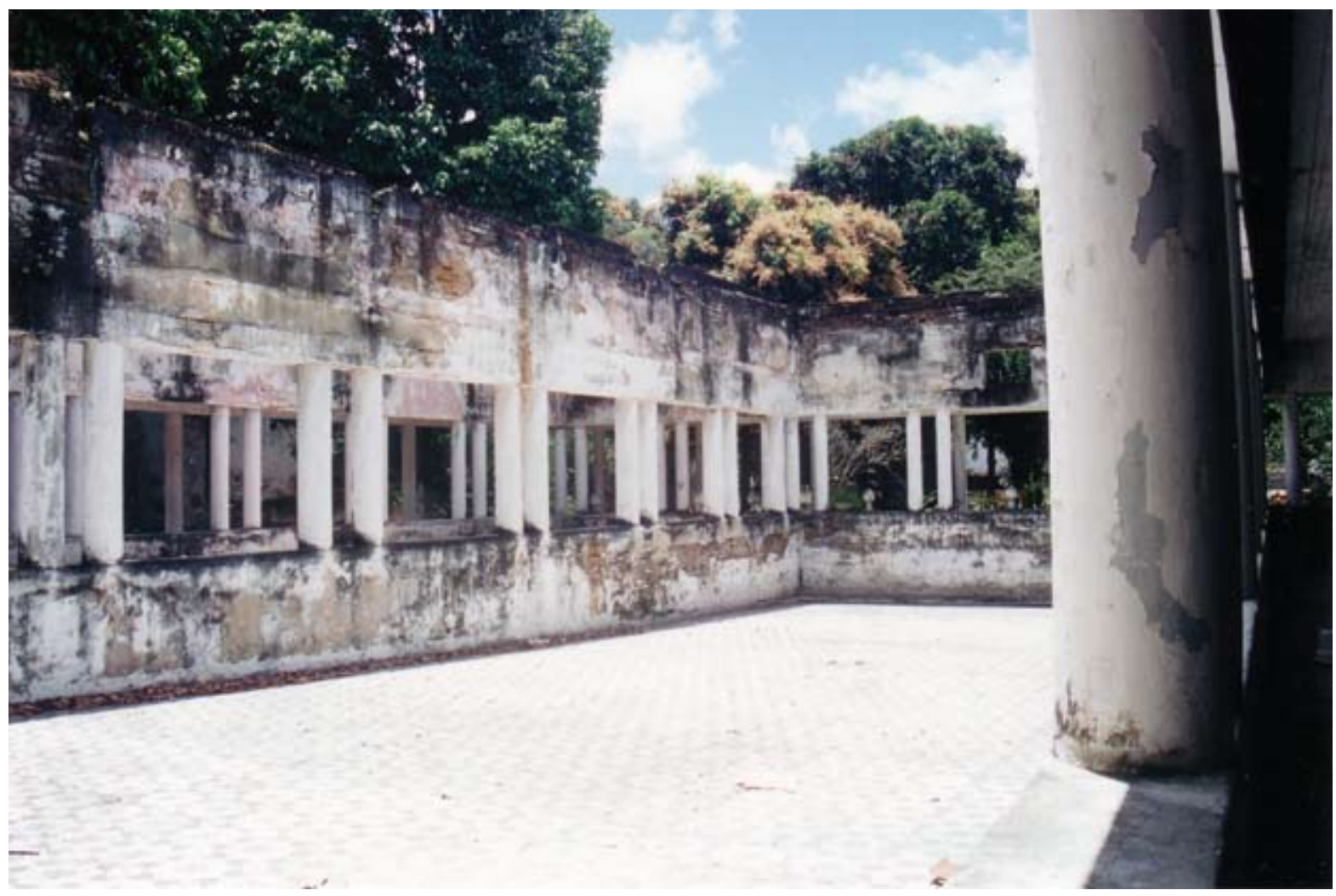

Figura 51 - Cinema da casa do industrial da Companhia Industrial Fiação e Tecidos Goyanna, em Goiana (PE). Fotografia de Philip Gunn, 2000. 


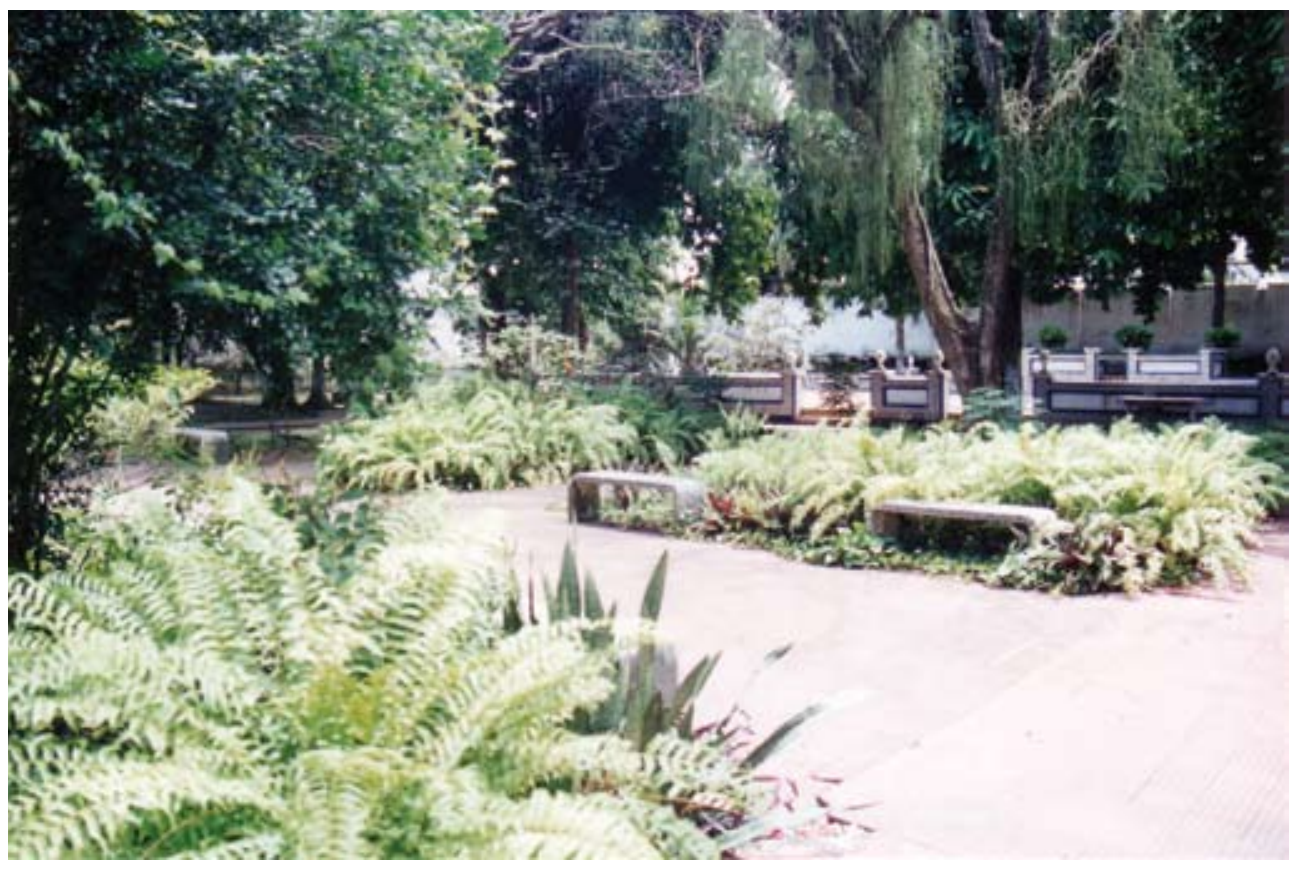

Figura 52 - Jardim com espaço para festas da casa do industrial da Companhia Industrial Fiação e Tecidos Goyanna, em Goiana (PE). Fotografia de Philip Gunn, 2000.

tanto de transição como de junção entre a casa e a rua. $\bigcirc$ cinema, o salão de jogos e o parque são espaços de acesso mais restrito, são privados e cercados, mas eventualmente se abriam à comunidade, que assistia a sessões gratuitas de cinema, usava o salão de jogos e participava de festas - de Natal e de Carnaval, por exemplo - que tinham lugar no parque. Uma sucessão de salões abertos para os jardins internos abrigava as áreas sociais da residência. Meias paredes, dotadas de eventuais cortinas, eram os únicos elementos que separavam tais espaços dos jardins e do cinema. As dimensões amplas dessas salas, isoladas entre si e dos jardins por colunas e meias paredes, evidenciam a ênfase conferida pelo programa da casa aos espaços de convivência, em detrimento das áreas íntimas e de serviços. Os salões tinham grande parte das paredes revestidas com azulejos portugueses retirados de casas demolidas quando da ampliação da fábrica e construção de sua vila operária. (Figuras 53 e 54).

Os demais espaços organizam-se em torno destes salões. A copa, um salão menor, situa-se em canto mais reservado. Dela se tem acesso a um bloco, que reúne cozinha, depósitos, despensa, lavanderia, pátio de serviços e dependências de empregados. Os salões dão acesso a um bloco, reunindo cinco quartos e um sanitário, destinados aos filhos maiores do industrial e aos hóspedes. Os aposentos privados do patrão e de seus filhos menores foram dispostos em um bloco situado no meio do jardim. Esta suíte - uma casa dentro da casa - conta com dois terraços, pequena sala íntima, sala de banhos e três quartos interligados. Trata-se de um espaço totalmente isolado do movimento de criados e visitantes, onde silêncio e privacidade estão assegurados (Figuras 55 e 56). 

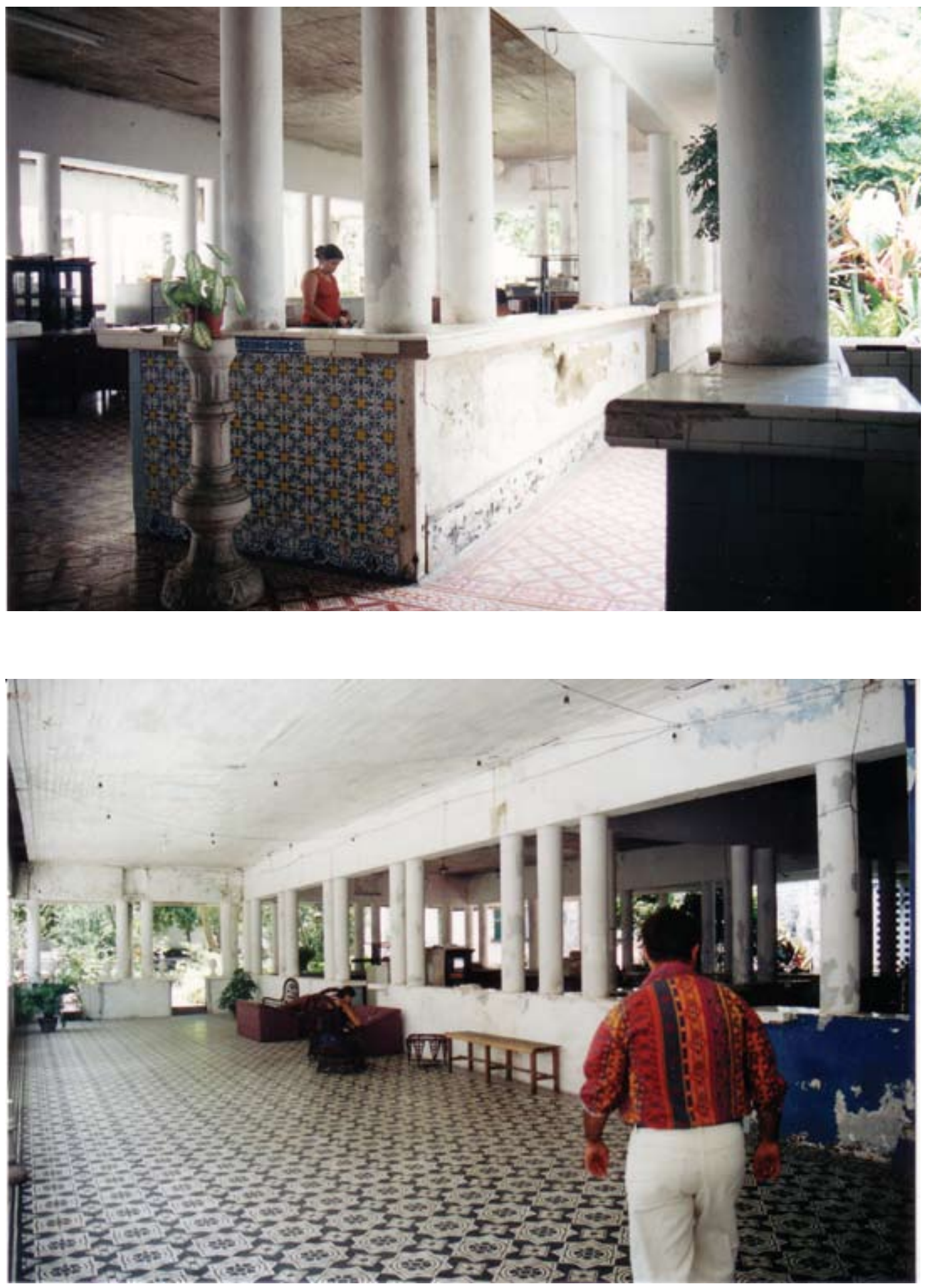

Figuras 53 e 54 - Salas da casa do industrial da Companhia Industrial Fiação e Tecidos Goyanna, em Goiana (PE). Fotografias de Philip Gunn, 2000. 


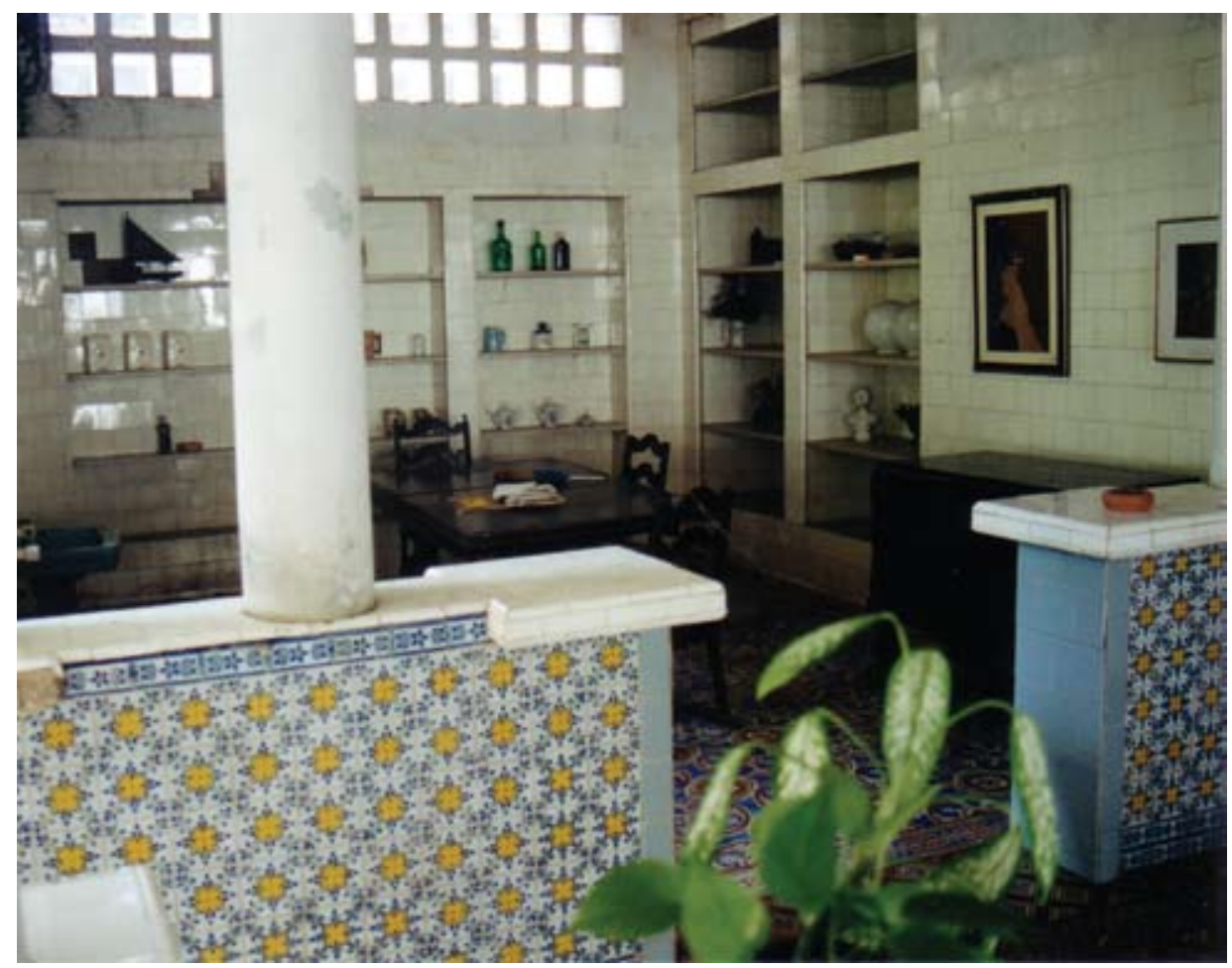

Figura 55 - Copa da casa do industrial da Companhia Industrial Fiação e Tecidos Goyanna, em Goiana (PE). Fotografia de Philip Gunn, 2000.

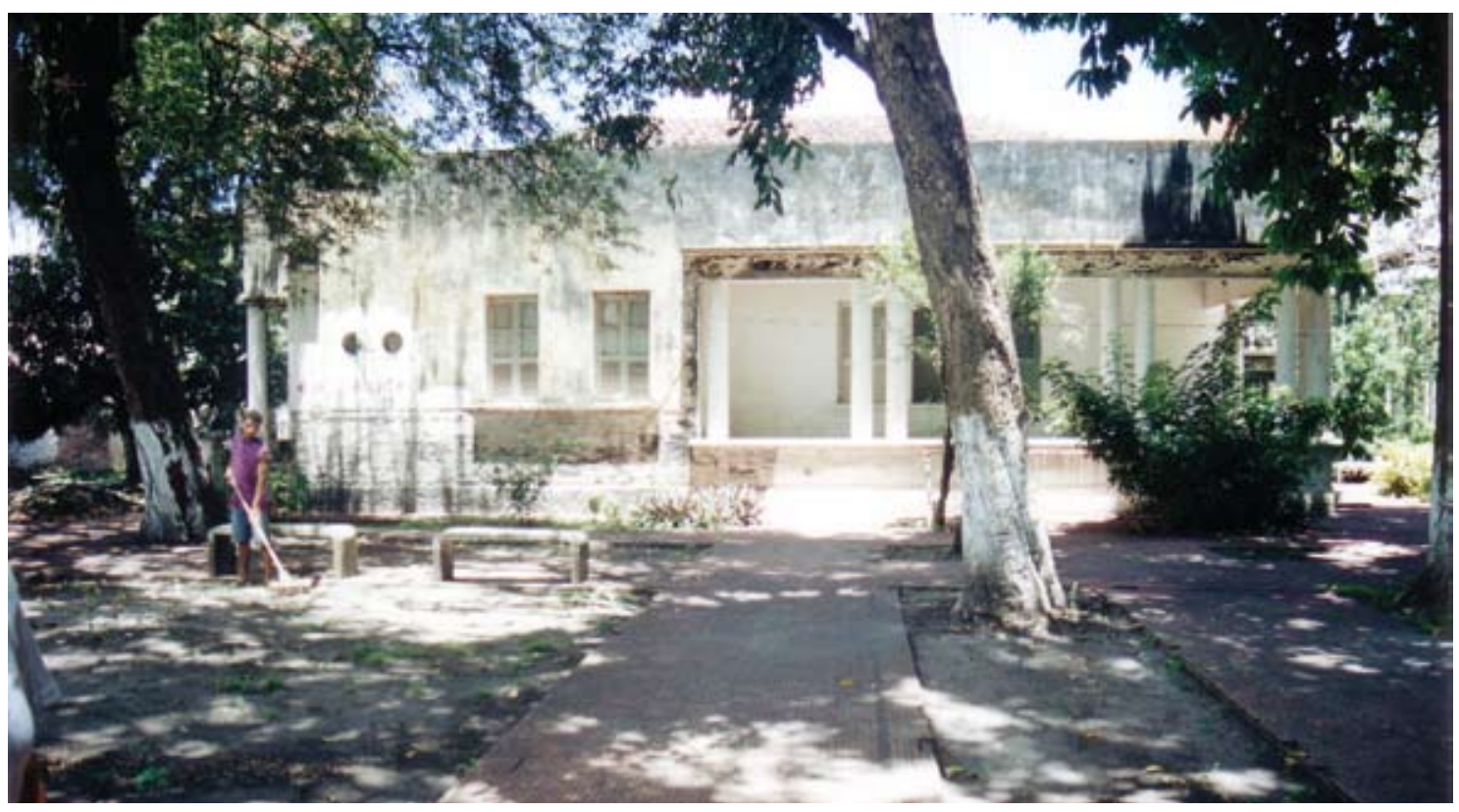

Figura 56 - Suíte da casa do industrial da Companhia Industrial Fiação e Tecidos Goyanna, em Goiana (PE). Fotografia de Philip Gunn, 2000. 
Além de solidário com o clima tropical, o uso de meias paredes entre os salões - e de painéis de elementos vazados em algumas paredes - propicia uma grande permeabilidade entre os espaços. Da rua, penetrava-se na galeria frontal aberta e, desta, vislumbravam-se os salões e os jardins através dos painéis vazados. A casa se deixa ver da rua, ao mesmo tempo em que se volta para seu jardim interno.

A disposição do jardim no fundo do lote e o deslocamento das áreas de serviço para a área mais próxima à rua são outros aspectos surpreendentes da casa, especialmente considerando a época em que foi construída e o fato de ter sido idealizada pelo próprio industrial. Na casa do industrial em Goiana, o jardim ganha a privacidade e a tranqüilidade dos antigos quintais. Sua forma e seu uso - voltado ao lazer e à contemplação -, entretanto, remetem ao jardim burguês do século XIX. As áreas de estar fazem a transição entre a rua e este jardim protegido, no centro do qual foram dispostos os aposentos privados do proprietário. Cozinha, pátio de serviço e dependências para empregados foram deslocados para uma extremidade lateral do lote, com acesso para a rua através de entrada disposta na fachada frontal. Um conjunto de quartos - destinados a hóspedes e filhos maiores - está implantado na parte frontal do lote.

A disposição do jardim nos fundos do lote e a implantação das áreas de estar entre ele e a rua remetem a uma prática que seria amplamente adotada em projetos de arquitetos brasileiros a partir de meados do século XX, quando surge como uma importante inovação projetual. Em Goiana, os salões já se configuram como interiores permeáveis, interligados aos jardins do ponto de vista físico e visual.

A ampliação e valorização dos ambientes de estar - em detrimento dos espaços íntimos e de serviços - é outra característica marcante da casa. Sua sucessão de salas interligadas e abertas para os jardins demarca um ambiente propício a uma vida familiar e social ativa. Esses espaços amplos e fluidos favorecem o convívio entre os moradores, ao mesmo tempo em que potencializam os contatos entre estes e os visitantes.

A fluidez entre salões e jardins encontra correspondência naquela entre galeria e rua, promovida pela continuidade da paginação de piso na calçada e na habitação. Trata-se de recurso solidário com uma maior permeabilidade entre lote e calçada, entre casa e rua, entre interior e exterior. Em Goiana, o mosaico em xadrez da galeria se prolonga - sem ser interrompido por qualquer tipo de desnível ou de barreira - na calçada frontal, interligando os dois espaços e convidando o transeunte a circular na galeria.

\section{Uma moradia para os trópicos}

Outros aspectos notáveis desta casa são os múltiplos recursos que a ela se incorporam, no sentido de adequá-la ao clima tropical: grandes painéis de elementos vazados, dispostos na copa e entre a galeria e os salões; galeria 
49. Cf. Alde Sampaio (1927, p. 31-43).

50. Ver Aluízio Bezerra Coutinho (1930).

51. Ver José Marianno Filho (1931, p. 317) protegendo a fachada frontal; salões permanentemente abertos para jardins internos; bandeiras dotadas de grades sobre portas; azulejos revestindo parte das paredes das áreas sociais (assim como as de banheiros, copa e cozinha); piso de mosaico; janelas com venezianas; pé direito alto e forro de madeira. Enfim, toda sua concepção conspira para tornar o interior ventilado, confortável, alegre e inusitado.

No Brasil, a adaptação da arquitetura ao clima tropical preocupou médicos, engenheiros e arquitetos desde o século XIX. Em Pernambuco, nas décadas de 1920 e de 1930, alguns profissionais se detiveram na apreciação da questão. O engenheiro Alde Sampaio sublinhava a necessidade de adaptação da habitação ao nosso clima e - como princípios básicos que, no seu entender, deveriam orientar nossas construções neste sentido -, propugnava a proteção contra o sol e a garantia de ventilação49. Em 1930, o médico pernambucano Aluízio Bezerra Coutinho, em tese apresentada na Faculdade de Medicina do Rio de Janeiro, tinha como preocupação central o ajuste da casa ao meio ambiente. Segundo ele, no caso dos países quentes, a criação de uma casa higiênica e confortável depende, sobretudo, do emprego de mecanismos capazes de combater o calor e a umidade ${ }^{50}$. $\bigcirc$ tema da adaptação da casa ao meio voltaria à pauta no Primeiro Congresso de Habitação, realizado em São Paulo em maio de 1931, através da fala de José Marianno Filho, médico pernambucano e ex-diretor da Escola de Belas Artes do Rio de Janeiro, em que defende uma arquitetura que seja "expressão do meio": que se harmonize com hábitos e costumes; que seja adequada aos materiais disponíveis; e que seja capaz de defender seu interior dos rigores do clima ${ }^{51}$.

Em Pernambuco, do ponto de vista da prática da construção, os propósitos de uma arquitetura solidária com o clima se expressaram no século XIX em construções incorporando varandas, terraços, portas e janelas dotadas de venezianas e de bandeiras com grades de ferro. Na década de 1930, os projetos concebidos pelo arquiteto Luiz Nunes para prédios institucionais fizeram amplo uso do cobogó, compondo extensas superfícies que funcionavam como brise-soleil e favoreciam uma permanente ventilação dos interiores.

A casa do industrial José Albino Pimentel em Goiana - erguida naquele momento - vai ao encontro de todas essas preocupações; suas soluções de projeto, porém, revelam uma resposta original às questões colocadas. Tal originalidade, de um lado, decorre do fato de não se tratar de obra projetada por profissional de arquitetura, mas por um industrial. De outro, indica a sua particular sensibilidade e criatividade na concepção da própria moradia. Dentre os múltiplos recursos nela utilizados para ventilar os seus interiores, vale assinalar a surpreendente simultaneidade entre seus painéis de elementos vazados e os projetados por Luiz Nunes em obras erguidas, na época, no Recife e em Olinda.

Em fotos antigas dos salões da moradia do industrial, pode-se observar que, algumas vezes, a mobília utilizada parece incompatível com os propósitos de adequação ao clima evidenciados na concepção da casa. Ao lado de 
despretensiosas cadeiras de balanço, com acentos de palhinha, é possível identificar também tapetes e pesados sofás estofados. Nessas fotos, também se vêem leves cortinas listradas isolando temporariamente alguns desses salões, conformando recantos mais protegidos e íntimos. Em outras fotos, pode-se visualizar os mesmos salões em dias de festa, com as cortinas abertas. Essa possibilidade de interligar ou segmentar os diversos salões de forma fácil e rápida introduz na moradia uma outra qualidade: a flexibilidade dos espaços. A sucessão de salões abertos que constituem a área social da residência compõe, antes de tudo, espaços flexíveis, adaptáveis tanto à rotina diária dos moradores quanto aos eventos que abrigavam, destinados a numerosas pessoas.

Nesta inusitada construção de viés déco, as soluções inovadoras em termos de programa, disposição em planta e materiais de construção surgem articuladas a elementos, reelaborados, da arquitetura clássica-loggias, óculos, colunas, platibanda etc. -, sem deixar de recuperar algo da herança colonial árabe/lusitana através dos belos azulejos portugueses antigos que revestem as paredes dos salões ${ }^{52}$

Art déco e indústria no Brasil: algumas tendências

Observando os exemplos tratados neste trabalho, pode-se constatar que nas construções erguidas por fábricas no Brasil, o gosto déco se expressou, sobretudo, através de volumes, platibandas e ornatos de formas escalonadas, coerentes com a tendência conhecida como zigzag modern. Alguns casos mais raros adotam formas arredondadas que remetem à tendência streamlined. São exemplos de uma versão de arquitetura de viés art déco - salvo exceções, bastante simplificada -, com uso de decoração despojada e de materiais de construção baratos. Na maioria dos casos, são construções em alvenaria de tijolos revestida com reboco. Com exceção das igrejas e de algumas das instalações fabris, nelas a estética déco é evidenciada, sobretudo, na forma de detalhes ornamentais das fachadas, que, por sua vez, são empregados de forma bastante parcimoniosa.

As platibandas são, de forma recorrente, o elemento que coroa a composição das fachadas. Nelas predominam soluções escalonadas, combinadas a superfícies lisas ou decoradas com frisos ou com relevos geométricos aplicados. Em alguns casos, a platibanda surge como um prolongamento da parede externa, recebendo como elemento de arremate apenas uma faixa delicadaou, além desta, uma outra faixa ou marquise estreita - definindo o limite inferior da platibanda.

Nas habitações operárias em grupos, dois elementos são freqüentes: os frontões escalonados e os frisos ou pilastras verticais nos limites das fachadas das casas. Ambos os recursos demarcam cada uma das casas quando - como ocorria com freqüencia - dispostas geminadas em longos blocos. Assim, a ênfase é colocada na repetição dos mesmos elementos de um modelo único (buscando
52. Após a morte de José Albino Pimentel, em 1954, a empresa deparou-se com momentos difíceis. A partir do final dos anos 1950, a fábrica viveu um longo período de crise, suspendendo suas atividades em 1957 e reiniciando-as em 1963. Em janeiro de 2003, atuava no beneficiamento de algodão. Ao longo desse processo, a indústria desfez-se de parte de seu patrimônio. Em 1968, a quase totalidade das casas da vila operária foi vendida aos moradores, através de financiamentos feitos pelo Banco Nacional de Habitação (BNH). Apenas parcialmente utilizado pela indústria, o prédio da fábrica teve partes subdivididas e alugadas a locatários diversos. A casa do industrial continuou sendo usada ocasionalmente por seus herdeiros. Seu cinema deixou de funcionar em meados da década de 1950 e, em 2000, era um espaço desprovido de cobertura. O prédio da sorveteria, após permanecer fechado durante anos, foi desapropriado em 1999 pela Procuradoria do Ministério Público. Apesar das lamentáveis reformas de algumas fachadas, parte significativa do conjunto de moradia para operários permanecia, em outubro de 2000 , preservada no seu aspecto exterior. O principal efeito arquitetônico da redução ou eliminação do controle da empresa sobre as moradias estava na diversificação das cores que cobriam as fachadas. Tal diversificação havia sido acentuada em decorrência de projeto da Prefeitura Municipal incentivando os proprietários a pintarem com cores vivas as fachadas de casas e de prédios que haviam abrigado as instalações fabris. 
unidade compositiva ao conjunto) e na demarcação dos limites de fachada das casas (buscando individualizar cada uma das moradias que compõem o conjunto).

Nos demais programas - clubes, escolas, igrejas e fábricas -, evidencia-se o uso de princípios de hierarquização, expressos em formas escalonadas e na ênfase ao acesso. Na maioria dos casos, tais prédios são tratados de modo a destacarem-se das casas, assim como a enfatizar suas partes julgadas mais relevantes. É comum a composição de suas fachadas denunciar uma busca de simetria e axialidade na distribuição da planta.

No caso dos clubes e escolas, os recursos ornamentais - marquises, colunas, frisos e desenhos geométricos, em alto ou baixo relevo, óculos e elevação das platibandas - foram empregados, sobretudo, no sentido de assinalar as entradas.

Nas igrejas, predominou uma composição de fachada escalonada e verticalizada - obtida através de uma volumetria bastante movimentada ou de elementos em relevo - que culmina em uma torre central, cuja ascendência sobre a composição (e sobre o conjunto das construções do seu entorno) é reforçada por vitral em forma de cruz delgada. Colocado em posição de destaque, o vitral domina a composição e destaca-se na paisagem noturna pelo uso cenográfico da iluminação elétrica, mobilizando um recurso importante do vocabulário art déco.

Nos prédios fabris identificados, o gosto déco preside composições escalonadas, com uso de frontões, de faixas verticais ou de superposição de volumes. Em todos os casos, tais elementos contribuem para acentuar a monumentalidade das construções, seja enfatizando a altura, seja assinalando a extensão horizontal dos amplos galpões industriais. Em prédios e em portarias, é freqüente a presença de soluções onde surgem quinas arredondadas. Nas fábricas, a hierarquização volumétrica fundamenta uma tipologia que se repete em quatro casos: composição de volumes dominada por uma torre central - cuja verticalidade é reforçada por linhas verticais obtidas através de rasgos ou de elementos em relevo - ostentando o nome da empresa e, no alto, um relógio, este símbolo do tempo linear que rege o trabalho industrial. Os vãos da torre central são tratados de modo a obter-se grande efeito cenográfico, sobretudo com a iluminação noturna dos ambientes internos. A torre confere ênfase ao acesso principal do prédio, que se dá, no térreo, através deste volume - caso da Fábrica Ypu, da Fábrica de Estamparia e Alvejaria Votorantim, e da Fábrica de Meias Luppo - ou de outro volume disposto em sua base - caso da Companhia Taubaté Industrial -, através de portão sob marquise. Em dois destes prédios - o da Luppo e o da CTI - as qualidades plásticas e a localização os converteram em marcos expressivos nas paisagens urbanas de Araraquara e de Taubaté.

As construções que compõem a fábrica e a vila operária criada pela Companhia Industrial Fiação e Tecidos Goyanna, em Pernambuco, compuseram - que foi provavelmente um dos mais notáveis conjuntos de arquitetura com tendência art déco entre os erguidos por fábricas no Brasil. Suas formas 
solidarizam-se com as tendências da arquitetura de viés déco gerada por indústrias no Brasil: uso de soluções construtivas econômicas, incorporando temas formais geometrizantes.

A Companhia Industrial Fiação e Tecidos Goyanna, entretanto, encontra particularidades na unidade formal do conjunto e, sobretudo, nas características da casa do industrial, que adota um programa inusitado e soluções arquitetônicas inovadoras no que tange à maneira como são tratadas as relações entre público e privado e entre exterior e interior, à busca de soluções adequadas ao clima tropical e à forma como recupera elementos da arquitetura clássica e da tradição árabe/portuguesa. O conjunto erguido pela fábrica em Goiana evidencia a importância da ação de industriais na construção do cenário urbano brasileiro e na adoção de soluções inovadoras no campo da arquitetura. Ao mesmo tempo, atesta os desígnios de constituição de novas formas de morar e revela uma arquitetura extremamente inovadora - em termos do programa e da forma - vinculada a uma linguagem que tem sido freqüentemente associada a meras aplicações ornamentais.

\section{REFERÊNCIAS}

\section{A. ANAIS E LIVROS}

ANTUNES, Duminiense Paranhos. Documentário bistórico do município de Caxias do Sul. São Leopoldo: Artegráfica, 1950.

BARDI, P.M. (ed.). Contribuição dos italianos na arquitetura brasileira. Belo Horizonte: Fiat do Brasil, 1981.

COUTINHO, Aluízio Bezerra Coutinho. O problema da babitação bigiênica nos paises quentes em face da Arquitetura Viva. Rio de Janeiro: Officinas Alba Graphicas, 1930.

LAMPUGNANI, V.M. (ed.). Enciclopédia GG de la arquitectura del siglo XX. Barcelona: Gustavo Gili, 1989.

MARGENAT, Juan P. Arquitetura art deco en Montevideo (1925-1950). Montevideo: Mercur, 2000.

MARIANNO FILHO, José. A architectura mesologica. In: CONGRESSO DE HABITAÇÃO, 1., 1931, São Paulo. Anais... São Paulo: Publicação Official / Escolas Profissionais do Lyceu Coração de Jesus, 1931, p. 311-322.

MARTINS, Kleber de A. Votorantim 2000: memórias de uma cidade. Votorantim: Prefeitura Municipal de Votorantim, 2000.

PALLADIO, Andrea. The four books of architecture. New York: Dover, 1965.

SPEER, Albert. Por dentro do III Reich. São Paulo: Círculo Do Livro, 1975.

\section{B. Teses, dissertações, monografias}


ANDRADE, Margarida Júlia Farias de Salles. Onde moram os operários... vilas operárias em Fortaleza: 1920-1945. 1990. 309 f. Dissertação (Mestrado em Desenho Urbano/Urbanismo) Faculdade de Arquitetura e Urbanismo, Universidade Federal da Bahia, Salvador, 1990.

CAMPOS, Vitor José Baptista. O Arte-déco na arquitetura paulistana. Uma outra face do moderno. 1996. 273 f. Dissertação (Mestrado em Arquitetura e Urbanismo) - Faculdade de Arquitetura e Urbanismo, Universidade de São Paulo, São Paulo, 1996.

GUNN, Philip; CORREIA, Telma de Barros. Levantamentos de Campo em vilas operárias e núcleos fabris no Brasil, 1996 a 2005.

NASLAVSKY, G. Modernidade arquitetônica no Recife: arte, técnica e arquitetura (1920-1950). 1998. 301 f. Dissertação (Mestrado em Arquitetura e Urbanismo) - Faculdade de Arquitetura e Urbanismo, Universidade de São Paulo, São Paulo, 1998.

PENNA, Renato et al. Vila Operária da Companbia Taubaté Industrial. 1992. Monografia. (Graduação em Arquitetura), Universidade de Taubaté, Taubaté, 1992.

PINHEIRO, Maria Lucia Bressan. Modernizada ou moderna? A arquitetura em São Paulo, 193845. 1997. 343 f. Tese (Doutorado em Arquitetura e Urbanismo) - Faculdade de Arquitetura e Urbanismo, Universidade de São Paulo, São Paulo, 1997.

QUEIROZ, Marcus Vinicius Dantas de. Quem te vê não te conbece mais: arquitetura e cidade de Campina Grande em transformação (1930-1950). 2008. 245 f. Dissertação (Mestrado) - Escola de Engenharia de São Carlos, Universidade de São Paulo, São Carlos, 2008.

\section{PERIÓDICOS}

ANDRADE, Paulo R. Uma outra cultura da modernidade. AU-Arquitetura e Urbanismo, São Paulo, ano 9, n. 51, p. 73-77, 1993.

ARCHITECTO J. Cordeiro de Azeredo. Pequena residência em arte moderna. A Casa, Rio de Janeiro, ano 6, n. 56, p. 21, dez. 1928.

A ARCHITECTURA e a estetica dos edifícios industriaes. Architectura e Construcções, São Paulo, v. 2, n. 24, p. 5-9, dez. 1931.

AS ESTAÇÕES influem decididamente na concepção do projeto. A Casa, Rio de Janeiro, ano 20, n. 217-218, p. 22, jun.-jul. 1942.

AS GRANDES obras da fábrica de tecidos. O Goianense, Goiana, ano 7, n. 310, p. 4, 25 out. 1936.

BIBLIOTHECA Municipal do Districto Federal. Architectura e Construcções, São Paulo, v. 3, n. 4, p. 43-45, abr. 1932.

CASA de campo. Dacy Roza, ENBA. A Casa, Rio de Janeiro, ano 10, n. 92, p.10, jan. 1932.

CASA projetada pelo arquiteto Alfredo Ernesto Becker. A Casa, Rio de Janeiro, ano 16, n. 173, p. 34-35, out. 1938.

COMPANHIA Industrial Fiação de Tecidos Goyanna. Cidade Mauricéa, Recife, ano 2, n. 15, jul. 1939. 
CONDE, Luis Paulo et al. Protomodernismo em Copacabana. AU - Arquitetura e Urbanismo, São Paulo, ano 4, n. 16, p. 68-75, fev.-mar. 1988.

CONSTRUÇÃO à rua Casimiro de Abreu. Projeto e execução: Saramago Fonseca e Soares. $A$ Casa, Rio de Janeiro, ano 16, n. 164, p. 22, jan. 1938.

CONSTRUÇÃO do Realengo. Escritório Técnico J. Cordeiro de Azevedo. A Casa, Rio de Janeiro, ano 16, n. 165 , p. 14 , fev. 1938.

CONSTRUÇÃO em lote estreito, executada em São Paulo pelo engenheiro-arquiteto Alfredo Ernesto Becker. A Casa, Rio de Janeiro, ano 18, n. 195-196, p.19, ago.-set. 1940.

EDIFÍCIO de apartamentos. A Casa, Rio de Janeiro, ano 16, n. 173-174, p.24, nov.-dez. 1938.

FÁBRICA de Tecidos Goiana. O Goianense, Goiana, ano 8, n. 332, p. 4, 18 abr. 1937.

Fábrica Nacional de Motores S.A. O Observador Econômico e Financeiro, São Paulo, ano 14, n. 160, p. 73-76, maio 1949.

O CENTRO Rockfeller. A Casa, Rio de Janeiro, ano 16, n. 167, p. 13; 40-42, abr. 1938.

O PRÉDIO Pirapitiguy. Architectura e Construcções, São Paulo, v. 2, n. 21 p. 17-33, jun. 1931.

PEQUENOS apartamentos para o bairro da Tijuca. Escritório Técnico J. Cordeiro de Azevedo. $A$ Casa, Rio de Janeiro, ano 17, n. 177, p. 31, fev. 1939.

PERSPECTIVA e projeto definitivo. Arquiteto Roberto Lacombe e Flavio Barbosa. A Casa, Rio de Janeiro, ano 17, n. 181, p. 17-22, jun. 1939.

PINHEIRO, Maria Lucia Bressan. Arquitetura residencial verticalizada em São Paulo nas décadas de 1930 e 1940. Anais do Museu Paulista, São Paulo, v. 16, n. 1, jan.-jun. 2008. Acessível em: $<$ http://www.scielo.br/pdf/anaismp/v16nl/04.pdf>.

PRÉDIO à rua Gastão Gonçalves. Projeto e execução: Saramago Fonseca e Soares. $A$ Casa, Rio de Janeiro, ano 16, n. 167, p. 30, abr. 1938.

PRÉDIO Japery. A Casa, Rio de Janeiro, ano 16, n. 164, p. 20, jan. 1938.

ARQUITETOS e Construtores Andrade Lima \& Cia. A Casa, Rio de Janeiro, ano 17, n. 180, p. 27, mai. 1939.

PRÉDIO à rua João Pessoa. Projeto e execução: Saramago Fonseca e Soares. $A$ Casa, Rio de Janeiro, ano 16, n. 164, p. 20, jan. 1938.

PRÉDIO construído à av. Brasil, Jardim Paulista, São Paulo. Projeto e construção de Alfredo Ernesto Becker. A Casa, Rio de Janeiro, ano 18, n. 191, p. 11, abr. 1940.

PRÉDIO de apartamento. Architectura e Construcções, São Paulo, v. 3, n. 5-6, p. 66-68, mai.-jun. 1932.

PROJETO de Alberto Lauria. A Casa, Rio de Janeiro, ano 6, n. 56, p. 41, dez. 1928.

PROJETO de A. Meira Filho, ambos executados em Belém do Pará. A Casa, Rio de Janeiro, ano 17 , n. 201-203, p. 26, fev.-abr. 1941.

Annals of Museu Paulista. v. 16. n.2. July - Dec. 2008. 
PROJETO de residência para o Sr. Kurt Schupp. Arquiteto Ladislau P. Kalocsai. A Casa, Rio de Janeiro, ano 17, n. 186-187, p. 14-15, nov.- dez. 1939.

PROJETO e construção Dourado S. A. A Casa, Rio de Janeiro, ano 20, n. 217-218, p. 16-17, jun.jul. 1942.

RESID NCIA à rua Tobias Amaral. Projeto e construção: Graça Couto \& Cia. A Casa, Rio de Janeiro, ano 18, n. 189-190, p. 7, fev.-mar. 1940.

SAMPAIO, Alde. A casa tropical. Boletim do Club de Engenharia de Pernambuco, Recife, ano 5 , v. 3, n. 2, p. 31-43, dez. 1927.

SÃO PAULO. Edifício Tabatinguéra. A Casa, Rio de Janeiro, ano 16, n. 171-172, p. 19, ago.-set. 1938.

SIGAUD, E. P. Arte decorativa. A Casa, Rio de Janeiro, ano 21, n. 227, p. 35, abr. 1943.

SOTO, Maria Cristina Martinez. Indústria e transformações urbanas: Taubaté 1891/1942. Revista de História, da Faculdade de Filosofia e Ciências Humanas da Universidade de São Paulo, São Paulo, n. 135, p. 79-100, jul.-dez. 1996.

VILA operária. O Goianense, Goiana, ano 7, n. 258, p. 4, 21 mar. 1936.

D. ENTREVISTA

Concedida à autora por Nelson Pimentel, no Recife, em janeiro de 2003.

Artigo apresentado em 8/2008. Aprovado em 10/2008. 